\title{
IDAHO NATIONAL ENGINEERING AND ENVIRONMENTAL LABORATORY SITE REPORT ON THE PRODUCTION AND USE OF RECYCLED URANIUM
}

\author{
L. C. Lewis \\ D. C. Barg \\ C. L. Bendixsen \\ J. P. Henscheid \\ D. R. Wenzel \\ B. L. Denning
}

Published September 2000

Idaho National Engineering and Environmental Laboratory Idaho Falls, Idaho 83415

\author{
Prepared for the \\ U.S. Department of Energy \\ Assistant Secretary for \\ Environmental Management \\ Under DOE Idaho Operations Office \\ Contract DE-AC07-99ID13727
}


Site Team Approval Sheet
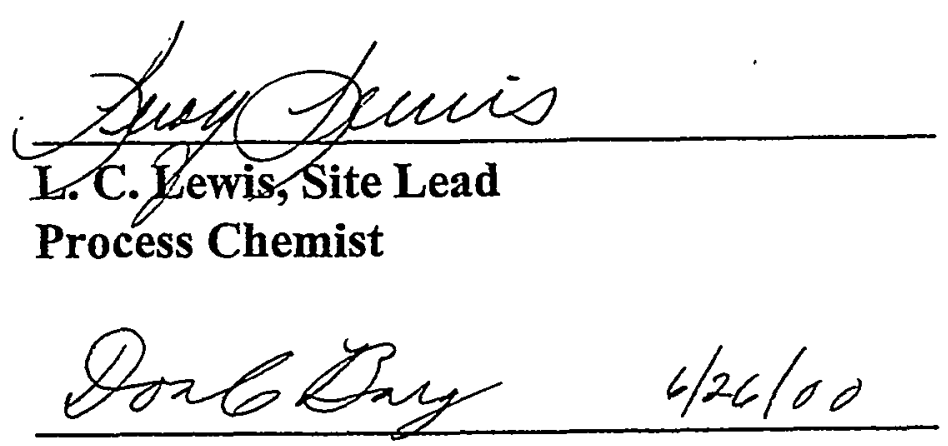

D. C. Burg, SMC Lead SMC Health Physics

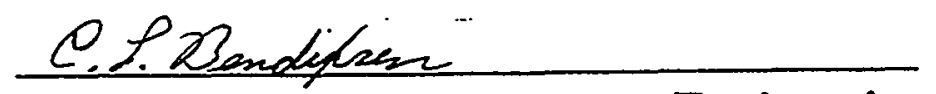

C. L. Bendixsen, ICPP Process Engineering
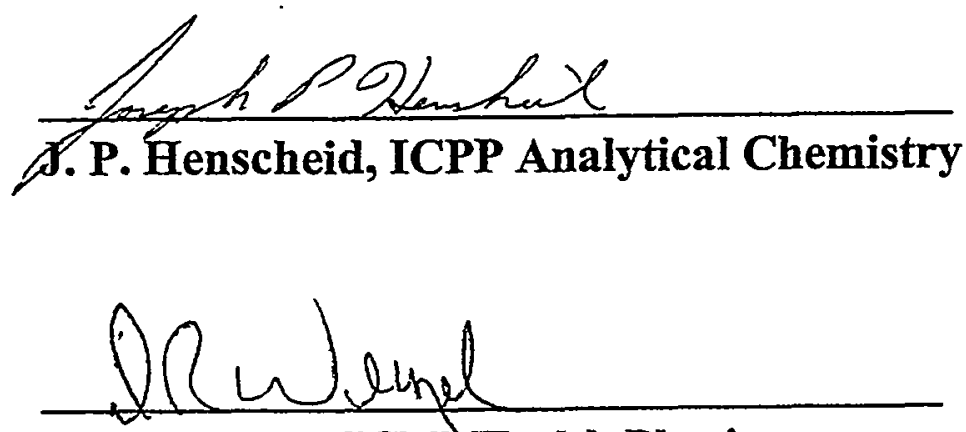

D. R. Wenzel, ICPP Health Physics

B. 1. Penning, Materials Control and Accountability 


\section{DISCLAIMER}

This report was prepared as an account of work sponsored by an agency of the United States Government. Neither the United States Government nor any agency thereof, nor any of their employees, make any warranty, express or implied, or assumes any legal liability or responsibility for the accuracy, completeness, or usefulness of any information, apparatus, product, or process disclosed, or represents that its use would not infringe privately owned rights. Reference herein to any specific commercial product, process, or service by trade name, trademark, manufacturer, or otherwise does not necessarily constitute or imply its endorsement, recommendation, or favoring by the United States Government or any agency thereof. The views and opinions of authors expressed herein do not necessarily state or reflect those of the United States Government or any agency thereof. 


\section{DISCLAIMER}

Portions of this document may be illegible in electronic image products. Images are produced from the best available original document. 


\section{Executive Summary}

Recent allegations regarding radiation exposure to radionuclides present in recycled uranium sent to the gaseous diffusion plants prompted the Department of Energy to undertake a system-wide study of recycled uranium. Of particular interest, were the flowpaths from site to site, operations and facilities in which exposure to plutonium, neptunium and technetium could occur, and to the workers that could receive a significant radiation dose from handling recycled uranium.

The Idaho site report is primarily concerned with two locations at the Idaho site. Recycled uranium was produced at the Idaho Chemical Processing Plant where highly enriched uranium was recovered from spent fuel. The other facility is the Specific Manufacturing Facility (SMC) where recycled, depleted uranium is manufactured into shapes for use by their customer.

The Specific Manufacturing Capability (SMC) is located in the Test Area North, which was originally built in the late 1950's to develop the nuclear aircraft. This development project was terminated and the SMC complex was later installed in the nuclear aircraft project building. SMC's current mission is the fabrication of components from depleted uranium for government purposes.

The SMC is a manufacturing facility that uses depleted uranium metal as a raw material that is then rolled and cut into shapes. There are no chemical processes that might concentrate any of the radioactive contaminant species. Recyclable depleted uranium from the SMC facility is sent to a private metallurgical facility for recasting. Analyses on the recast billets indicate that there is no change in the concentrations of transuranics as a result of the recasting process.

The Idaho Chemical Processing Plant is located in south-eastern Idaho at the Idaho National Engineering and Environmental Laboratory (INEEL). The facility was built to recover highenriched uranium from spent nuclear fuel from test reactors. The facility processed diverse types of fuel which required uniquely different fuel dissolution processes. The dissolved fuel was passed through three cycles of solvent extraction which resulted in a concentrated uranyl nitrate product. For the first half of the operating period, the uranium was shipped as the concentrated solution. For the second half of the operating period the uranium solution was thermally converted, granular, uranium trioxide solids.

Approximately $85 \%$ of the uranium product was shipped to the $\mathrm{Y}-12$ facility at Oak Ridge. Most of the rest was shipped to the Portsmouth Gaseous Diffusion Plant. Small quantities were shipped to Rocky Flats, Pacific Northwest National Laboratory, and to Los Alamos for their use in criticality experiments.

Shipments from ICPP were begun in 1953 and contained until 1998. During this time period there was 32.005 tonnes of high enriched uranium product produced. In addition, there was approximately $20 \mathrm{Kg}$ of material received at ICPP from Y-12 which was a denitrated uranium trioxide which was to be used as the start up bed for denitrating the product. A second shipment 
was received from Pacific Northwest National Laboratory at the conclusion of their criticality experiments. The material that was sent back was approximately one-half of the $47 \mathrm{Kgs}$ of uranium that was sent to them in 1978. There were three shipments of uranium from the processing of the stainless steel clad EBR-II fuel consisting of a total of 4.08 metric tonnes of uranium at an enrichment of 50\%. There was also $219.10 \mathrm{Kgs}$ sent to Rocky Flats in 1955 and there was $167.61 \mathrm{Kgs}$ sent to Los Alamos in 1984. There is 1.770 tonnes of uranium currently in storage at ICPP. Everything else was shipped to Y-12.

Throughout the history of the ICPP, the uranium product was monitored for its transuranic alpha content, beta content and occasionally for its gamma content. The alpha content was consistently below the informal and formal specification. In the early years the beta ratio was greater than the specification but this was also reduced to a level below the specification limits. The beta emitting contaminant was primarily ruthenium because it was not very effectively removed by the hexone extraction cycles. When the tributyl phosphate cycle was introduced the ruthenium concentration decreased. Uranium-236 and uranium-234 were also significant contaminants in the ICPP product. Uranium-236 was produced by activation of the uranium while it was in the reactor, while uranium-234 was prefentially enriched in the gaseous diffusion plants; and neither uranium isotope could be removed by chemical processing. Technetium- 99 was not measured in the uranium product because it was not considered to be a problem during all the years of processing. Its concentration was believed to be insignificant compared to ruthenium.

Currently ICPP has in its recycled uranium product inventory, 1.770 MTU of high enriched uranium trioxide. Most of this material contains a high concentration of U-236 which can result in significant gamma fields when secular equilibrium is approached.

Worker exposure occurred throughout the operating history of the ICPP as the result of normal operations, maintenance activities, analytical chemistry activities, and health physics activities. In the early years personnel were pushed close to the annual or quarterly limits. From the mid 1970 s on, workers were closely monitored to make certain that they did not exceed 3 rem per year. The facilities in which exposures took place included all of the facilities where irradiated material was handled or stored. These facilities included CPP-603, CPP-601, CPP-602, CPP627, CPP-640, CPP-684, CPP-604, CPP-630, CPP-633, CPP-666, and CPP-659. The facilities were the primary fuel processing, waste processing, maintenance, analytical chemistry, and fuel storage facilities. All of these facilities contributed to worker exposure because the ICPP facility was a direct maintenance facility.

The dose reconstruction project has evaluated worker exposure and exposure to the public as the result of normal operations and accidents that occurred at the INEEL. As a result of these studies, the maximum effective dose equivalent from site activities did not exceed seventeen percent of the natural background in Eastern Idaho. There was no year in which the radiation dose to the public exceeded the applicable limits for that year. Worker exposure to recycled uranium was minimized by engineering features that reduced the possibility of direct exposure. 
The SMC facility only worked with depleted uranium metal. It received only one lot, and all of its processing activities have been with that lot of material. Metallic waste has been sent to a private recasting company. The quantities of transuranics and technetium have been below the de minimis levels, and SMC performs no operations that would result in concentrating or release of any of the contaminants. There have been no releases of this material to the environment from the SMC site. No uranium attributable to SMC operations has been found outside the SMC facility fence. 
Title Page

Executive Summary

Table of Contents

iii

List of Table

List of Figures

Acronyms

Introduction to the INEEL Report

1.0 Idaho National Engineering and Environmental

Laboratory Recycled Uranium Mass Balance Project 2

1.1 Project Overview 2

1.2 Purpose and Scope

1.3 Project Implementation Strategies 4

2.0 Site Historical Overview 5

2.1 Idaho Chemical Processing Plant Location $\quad 5$

2.2 Key Uranium Processing Facilities 5

2.2.1 Idaho Chemical Processing Plant 8

2.2.1.1 Plant Description $\quad 8$

2.2.1.2 Material Flowsheet 14

2.2.1.3 Feed Specifications 15

2.2.1.4 Product Specifications 15

2.2.15 Operating History 15

2.2.1.6 Current Status 15

2.3 Activity Summaries 15

2.3.1 Bottling Liquid Product 18

2.3.2 Packaging Solid Product 18

2.3.3 Analysis of Liquid Product 18

2.3.4 Operating the Denitrator 18

2.3.5 Maintenance on the Denitrator 18

2.3.6 Health Physics Surveillance During Denitrator Operation 18

2.3.7 Health Physics Monitoring During Liquid Product Bottling 19

2.4 Work Force Exposure $\quad 19$

2.5 Environmental Releases 24

3.0 Recycled Uranium Mass Flow 26

3.1 Uranium Recycle Description $\quad 26$

3.2 Uranium Receipts 26

3.3 Uranium Shipments 26

4.0 Constituents in Recycled Uranium 36

4.1 Analytical Laboratories $\quad 36$

4.1.1 Analytical Methods $\quad 36$

4.1.2 Analytical Methods 36 
Table of Contents (continued)

4.1.3 Processing Issues $\quad 36$

4.1.4 Quality Assurance 36

4.2 Neptunium, Plutonium, and Technetium in ICPP Uranium Product
as Estimated by ORIGEN2 Calculations

4.3 Analytical Results for Plutonium 46

4.3.1 Plutonium Specification

4.3.2 Impurity Concentrations for Plutonium in Materials Shipped 46

4.4 Analytical Results for Neptunium in Uranium Materials Shipped 47

4.4.1 Neptunium Specifications Uranium Materials Shipped 47

4.4.2 Impunity Concentration for Neptunium in Recycled Uranium Shipped 47

4.5 Analytical Results for Technetium in Uranium Materials Shipped 47

4.5.1 Technetium Specification in Recycled Uranium 47

4.5.2 Impurity Concentration for Technetium in Uranium Materials Shipped 47

4.6 Analytical Results for Material Received 47

4.7 Discussion of Other Constituents 47

$\begin{array}{lll}5.0 \text { Mass Balance Activities } & 51\end{array}$

5.1 Annual Mass Balance of Recycled Uranium 51

5.2 Annual Mass Balance for Plutonium $\quad 51$

5.3 Annual mass Balance for Neptunium 51

5.4 Annual Mass Balance for Technetium-99 51

5.5 Annual Mass Balance for Other Constituents 55

5.6 Potential for Worker Exposure from Recycled Uranium 55

5.7 Potential for Environmental Contamination from Recycled Uranium 55

6.0 Results and Conclusions 55

6.1 Explanation of mass Flow Paths and Contaminant Levels 55

6.2 Identification of Processes or Areas of Concern for Worker Exposure 56

6.3 Identification of Processes or Areas of Concern for Environmental Impact 56

6.4 Discussion of Data Sources and Confidence Levels 56

6.5 Conclusions 58

$\begin{array}{llr}7.0 & \text { References } & 59\end{array}$

$\begin{array}{ll}\text { Appendix } & 60\end{array}$ 
Table I ICPP Activity Chart

Table II Lung Clearance Classes Used to Determine the Relative Hazard fromVarious Isotopes

Table III Comparative Risk and Effective Dose Equivalent for Isotopes in the Product from Processing at ICPP

Table IV Shipments of Final Product

Table V Fuel Processed at ICPP

Table VI ORIGEN2 Results in Terms of Grams/100grams of Uranium

Table VII ORIGEN Result in Terms of Ci/gU

Table VIII Comparison of Pu/U Mass Ratios from Measured Decontamination Factors and Alpha Ratios

Table IX Contaminants in ICPP Product. Based on ORIGEN2 Code Calculations and DFs from ICPP Process Data

Table X

Uranium-236 Content of ICPP Fuels

Table XI Uranium-236 Quantities Sent to Receiving Sites

Table XII

Concentration of Contaminants in ICPP Product

Table XIII

Contaminants in ICPP Product

Table XIV

Material Shipped from ICPP

Table XV

Recycled Uranium Shipment

Table XVI

Ranges of Contaminants 


\section{List of Figures}

Figure 1 The Idaho Chemical Processing Plant as it Exists Today

Figure 2 Historical Time Line of Important Events at Idaho

Chemical Processing Plant

Figure $3 \quad$ Flowsheet of Processes used at ICPP

\section{Appendix Figures}

Figure A1

Figure A2

Figure A3

Figure A4

Figure A5

Figure A6

Figure A7

Figure A8

Figure A9

Figure A10
Simplified Chemical Flowsheet

Processing Flowsheet for Dissolution of Aluminum Fuels and First Cycle Solvent System Processing of the Aluminum Dissolver Product

Zirconium Processing Flowsheet for Campaigns 33 and 35

Campaign 37 Electrolytic Dissolver Flowsheet for Processing Borax V Type Fuels (0.4 g SS dissolved/amp - hr)

Campaign 37 Flowsheet for Processing Dissolver Product Through The First Cycle Extraction System with No Raffinate Recycle

Coprocessing Dissolver Flowsheet for Campaign 30: PWR-ATR Fuels

Flowsheet for Burnig of ROVER Fuel

Flowsheet for Dissolution of ROVER Ash

Campaign 37 Second and Third Cycle Extraction Flowsheet for High Uranium Concentration Feed

Campaign 37 Denitration Flowsheet for concentrated $\mathrm{UO}_{2}\left(\mathrm{NO}_{3}\right)_{2}$ Solutions 
Acronyms

$\begin{array}{ll}\text { AEC } & \text { Atomic Energy Commission } \\ \text { ALARA } & \text { As Low As Reasonably Achievable } \\ \text { AMAD } & \text { Activity Median Aerodynamic Diameter } \\ \text { BBWI } & \text { Bechtel BWXT Idaho } \\ \text { CEDE } & \text { Committed Effective Dose Equivalent } \\ \text { CPM } & \text { Continuous Processing Modification } \\ \text { DF } & \text { Decontamination Factor } \\ \text { DOE } & \text { Department of Energy } \\ \text { DPM (dpm) } & \text { Disintegration Per Minute } \\ \text { DPS (dps) } & \text { Disintegrations Per Second } \\ \text { DU } & \text { Depleted Uranium } \\ \text { EBR-I } & \text { Experimental Breeder Reactor I } \\ \text { EBR-II } & \text { Experimental Breeder Reactor II } \\ \text { FAST } & \text { Fluorinel and Storage Facility } \\ \text { FDP } & \text { Fluorinel Dissolution Process } \\ \text { FECF } & \text { Fuel Element Cutting Facility } \\ \text { HEU } & \text { High Enriched Uranium } \\ \text { ICPP } & \text { Idaho Chemical Processing Plant } \\ \text { IDMS } & \text { Isotope Dilution Mass Spectrometry } \\ \text { IFSF } & \text { Irradiated Fuel Storage Facility } \\ \text { INEEL } & \text { Idaho National Engineering and Environmental Laboratory } \\ \text { MTR } & \text { Materials Testing Reactor } \\ \text { NBS } & \text { National Bureau of Standards } \\ \text { NIST } & \text { National Institute of Science and Technology } \\ \text { NP } & \text { Neutron Producing } \\ \text { NWCF } & \text { New Waste Calcination Facility } \\ \text { ORIGEN } & \text { Oak Ridge Isotope Generation and Depletion } \\ \text { PGDP } & \text { Portsmouth Gaseous Diffusion Plant } \\ \text { RAF } & \text { Remote Analytical Facility } \\ \text { RAL } & \text { Remote Analytical Laboratory } \\ \text { RALA } & \text { Radioactive Lanthanum } \\ \text { ROVER } & \text { Nuclear Rocket Program } \\ \text { SMC } & \text { Special Manufacture Capability } \\ \text { TAN } & \text { Test Area North } \\ \text { TRU } & \text { Transuranic } \\ \text { WCF } & \text { Waste Calcination Facility } \\ \text { Y-12 } & \text { Weapons Plant at Oak Ridge, TN } \\ & \\ & \end{array}$




\section{Introduction to the INEEL Report}

The Idaho National Engineering and Environmental Laboratory (INEEL) was originally an isolated area whose specific purpose was the testing of various reactor concepts. The space available at the INEEL permitted wide spacing between reactor sites so that an incident at one site would not adversely affect activities at another site. In support of the reactor development activities the Idaho Chemical Processing Plant (ICPP) was built originally to recover the precious and rare enriched uranium from the spent fuel used in the reactors at the INEEL. Thus, the ICPP became a "source" of recycled uranium in the DOE complex.

In the early 1980 s an existing facility at Test Area North was retro fitted to manufacture depleted uranium tank armor. The hanger that was built for the nuclear aircraft program houses this facility. This facility became the only "user" of recycled uranium at the INEEL.

Thus, the INEEL has two missions with respect to recycled uranium, one as a "source" and the other as a "user." Because the problems and the discussions are so totally different, this report will detail each as a separate report.

The Specific Manufacturing Capability part falls clearly into a de minimis category. They have only worked with one lot of material of which they still have some. As the result, samples that were recently analyzed showed that they had only traces of the elements of interest. Because there is no process which concentrates any of the minor constituents in their uranium they do not expect to have any problems with either handling their material or sending the scrap back to the fabricator.

The ICPP recycled uranium that had been irradiated in a reactor. The spent fuel material was processed in remote cells and using remoted equipment. There was little opportunity to be exposed to the fuel or to the product. Most of the ICPP product was sent to Y-12 where it was purified again before being made into metal for fabrication into driver fuel for the Savannah River production reactors.

The ICPP processed approximately 30 metric tons of high enriched uranium product either as uranyl nitrate in solution or as uranium trioxide powder. The SMC facility used 6,800 metric tons of high quality depleted, uranium metal. Neither quantity is large compared to the balance of the complex. 
1.0 DAHO NATIONAL ENGINEERING AND ENVIRONMENTAL LABORATORY RECYCLED URANIUM MASS BALANCE PROJECT

1.1 Project Overview

The Idaho National Engineering and Environmental Laboratory (INEEL) was a source of recycled uranium recovered from spent fuel at the Idaho Chemical Processing Plant (ICPP) and was a receiver of recycled uranium at the Special Manufacturing Capability (SMC). Spent nuclear fuel from DOE-owned research and naval propulsion reactors was sent to the ICPP where it was dissolved, the uranium separated from the cladding and the fission products, and the uranium product shipped to other DOE-complex sites. The recycled uranium used at the SMC facility was fabricated into special shapes for their customer.

Because recycled uranium was implicated as a source of radiation dose to workers at the gaseous diffusion plants and associated linked plants in the DOE-complex, the uranium mass balance project was commissioned to identify other areas where recycled uranium could have caused dose to workers without their knowledge. The project is under the auspices of the Office of Nuclear Safety (EH-3) and chartered with reviewing the characteristics and flow of recycled uranium throughout the DOE Complex. This report specifically addresses the uranium mass balance for the INEEL.

The Bechtel BWXT Idaho Company (BBWI), under prime contract to DOE, was directed to prepare the INEEL site report for inclusion in the overall mass balance project report. A team consisting of six current contractor employees with a cumulative experience of 175 years at the ICPP was organized to research records of the activities and operations used with recycled uranium. Activities at ICPP were associated only with recycling uranium from spent fuel. By definition, the "recycled uranium" includes only the uranium after it has been separated from the fission products and concentrated to two hundred or more grams per liter or converted to uranium trioxide.

Data sources were researched to determine the quantity and transaction date of all the uranium shipped from ICPP, and attempts to corroborate shipments were made with the principal recycled uranium receivers. Of particular concern were the years from 1953 to 1966, when the shipping forms were missing. A spot check of the receiver's copy at $\mathrm{Y}-12$ indicated that the figures on a cumulative shipping compilation were accurate.

Most analytical data files were sent to a records repository where they were destroyed after five-years of storage. The only analytical data remaining is a limited amount of data in computer files in the analytical department and some late 1980s data that is still in the repository because of a moratorium on records 
destruction. No technetium measurements were ever made because technetium contamination was not a significant problem in ICPP product.

In order to compensate for the lack of data, ORIGEN2 calculations were made for the different worst case fuels that were typical of fuels processed at ICPP. These fuels were for high-burnup, aluminum-clad MTR fuel; low-burnup, fast-reactor EBR-II fuel, and a high-burnup, zirconium-clad fuel. The results of the calculations were checked against uranium, neptunium, and plutonium isotopic analytical data and were found to agree relatively well with actual analytical data for dissolver product composite samples. As such, the ORIGEN2 calculations gave the radionuclide composition for the dissolver product.

Many of the run reports included decontamination factors that measured the decontamination of alpha, beta, and gamma radionuclides through the extraction cycles. From that data, the alpha, beta, and gamma emitting radionuclides can be determined in the final product.

Some data also existed on the alpha ratio, which was used as a measure of the alpha purity of the uranium product. Knowing how the alpha ratio was defined, allowed analysts to estimate the amount of transuranic elements shipped with the product. Thus, an accurate estimate could be made of the amount of contaminants present in the recycled uranium product. These estimates bound the amounts of isotopes in recycled uranium that the ICPP workers were exposed to when handling the product. It is interesting to note that when a calculation was made to determine the relative risk for various radionuclides in the product, those that had the highest risks were from some of the uranium isotopes. Based on current estimates, ICPP workers had the greatest potential for dose during:

1) Packaging the product.

2) Maintenance activities associated with repairs to the denitrator or the liquid handling system.

3) Analysis of final product samples.

4) Radiation monitoring of these activities.

Since the plant started up, there have been many cases of worker dose including some to recycled uranium. There have been cases of internal dose that occurred during extraction and dissolution operations.

\subsection{Purpose and Scope}

The purpose of this project is to estimate the historical mass flows and characteristics of the recycled uranium produced at ICPP and shipped to other sites in the DOE complex. The information from this project will enable DOE to assess the potential for worker dose and environmental contamination from recycled uranium. Of particular interest in the ICPP product were isotopes of 
plutonium and neptunium and technetium-99. Uranium-236 is also of interest. This project focuses on:

1) Identifying the mass flow of $\mathrm{DOE}$ recycled uranium from the startup of fuel reprocessing at ICPP in February 1953 until March 31,1999 . This includes the sites where the recycled uranium was shipped. The ICPP shipped concentrated uranyl nitrate solution in nitric acid from 1953 until 1971. After 1971, uranium was shipped as solid, granular, uranium trioxide.

2) Identifying the major facilities where uranium was processed, and resulted in concentration of the fission products and the actinides. The streams from these processes are characterized to permit an assessment of worker or public health and safety issues.

3) Performing a site mass balance to the degree that existing mass and analytical data exists.

Items that are specifically excluded are:

1) Radioactive sources and standards. These items are typically sealed or are used as laboratory reagents. Their mass is accounted for through either the source control program or the nuclear materials control and accountability program. Their use is controlled to assure worker safety and, therefore, is not considered relevant to this study.

2) Uranium containing streams upstream of the liquid product evaporator. The exposure risks from material upstream is significantly higher than is found in recycled uranium. Because of the higher risk, this material is processed in heavily shielded cells using remote processing technology. Because this material is rarely accessible to workers and, when accessible is under strict control to minimize doses, all material and waste streams upstream of the product evaporator are outside the scope of this study. The uranium was not "recycled uranium" until it was ready to ship from ICPP.

1.3 Project Implementation Strategies

The project goals are as follows:

1) Identify the mass flow of recycled uranium from plant startup in 1953 until March 31, 1999 including the destination for recycled uranium shipments.

2) Identify the characteristics and contaminants in ICPP produced uranium product. Of particular interest are isotopes of uranium, plutonium, neptunium-237 and technetium-99.

3) Identify locations where potential exposure to hazardous contaminants in recycled uranium can occur at the ICPP. 
The strategy for accomplishing the mass balance project at ICPP is as follows:

1) Utilize existing DOE and Bechtel BWXT LLC protocols, procedures, and controls.

2) Obtain and utilize existing staff specialists and support personnel.

3) Establish a structured approach to meeting the project goals including the use of key assumptions.

4) Ensure effective communication of progress, issues, and problem resolution through regular meetings with project personnel.

5) Coordinate with other sites and share results.

\subsection{SITE HISTORICAL OVERVIEW}

2.1 The ICPP is located near the center of the 900 square mile INEEL which was formerly the National Reactor Testing Station (NRTS). The plant occupies approximately one square mile near the test reactors in an area that had formerly been used by the Navy for test firing large guns following relining of the barrels. The current facility/layout is shown in Figure 1.

2.2 Key Uranium Processing Facilities

The ICPP corner stone was laid in 1951. The Atomic Energy Commission (AEC) contractor during construction was the American Cyanamid Corporation. The construction contractor was the Blaw-Knox Company. The facility was designed by personnel at the Oak Ridge Laboratory Facility. In February of 1953 the first fuel (a slug from a Hanford production reactor) was charged to the dissolver. The dissolver product was purified using three cycles of methyl isobutyl ketone (hexone) extraction in packed columns. The acidic first cycle waste was stored in a cooled, 300,000-gallon, stainless steel tank located in a concrete vault. The acidic second and third cycle waste was stored in a second 300,000-gallon, stainless steel tank located in a separate concrete vault. The product from this processing campaign was sent to the $\mathrm{Y}-12$ facility at Oak Ridge to determine whether the product met the acceptance criteria. It was subsequently accepted, and the plant began processing fuel. The plant processed fuel from that initial campaign in 1953 until 1992 when fuel reprocessing was discontinued by a secretarial edict from then DOE Secretary James Watson. A clean-out campaign was completed in 1996 and the product from that campaign,which only recovered uranium from solutions in storage in the plant, is still in storage at ICPP.

The historical development of the uranium recovery process is shown in Figure 2. 
Figure 1

THE IDAHO CHEMICAL PROCESSING PLANT AS IT EXISTS TODAY

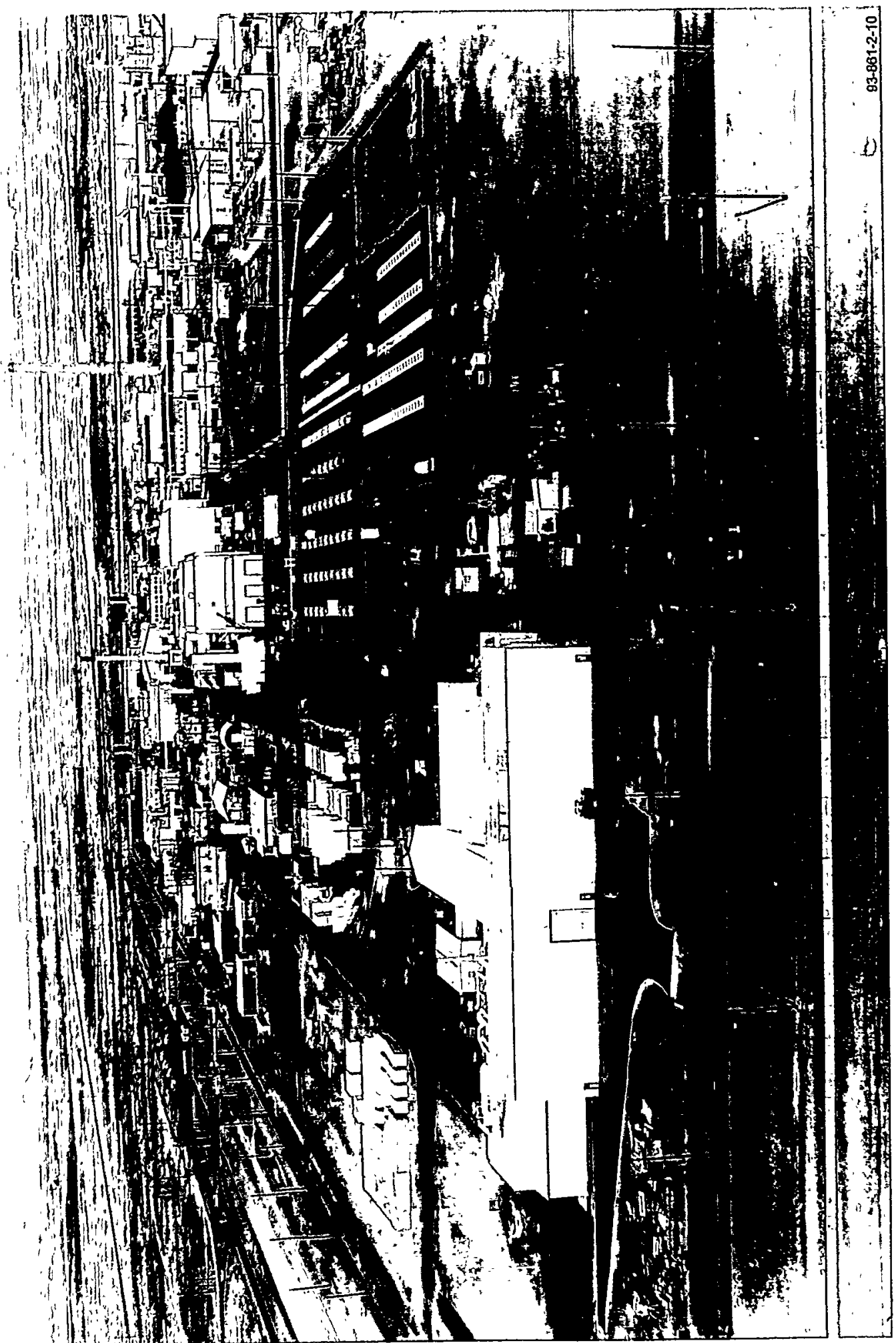


Figure 2

HISTORICAL TIME LINE OF IMPORTANT EVENTS AT

IDAHO CHEMICAL PROCESSING PLANT

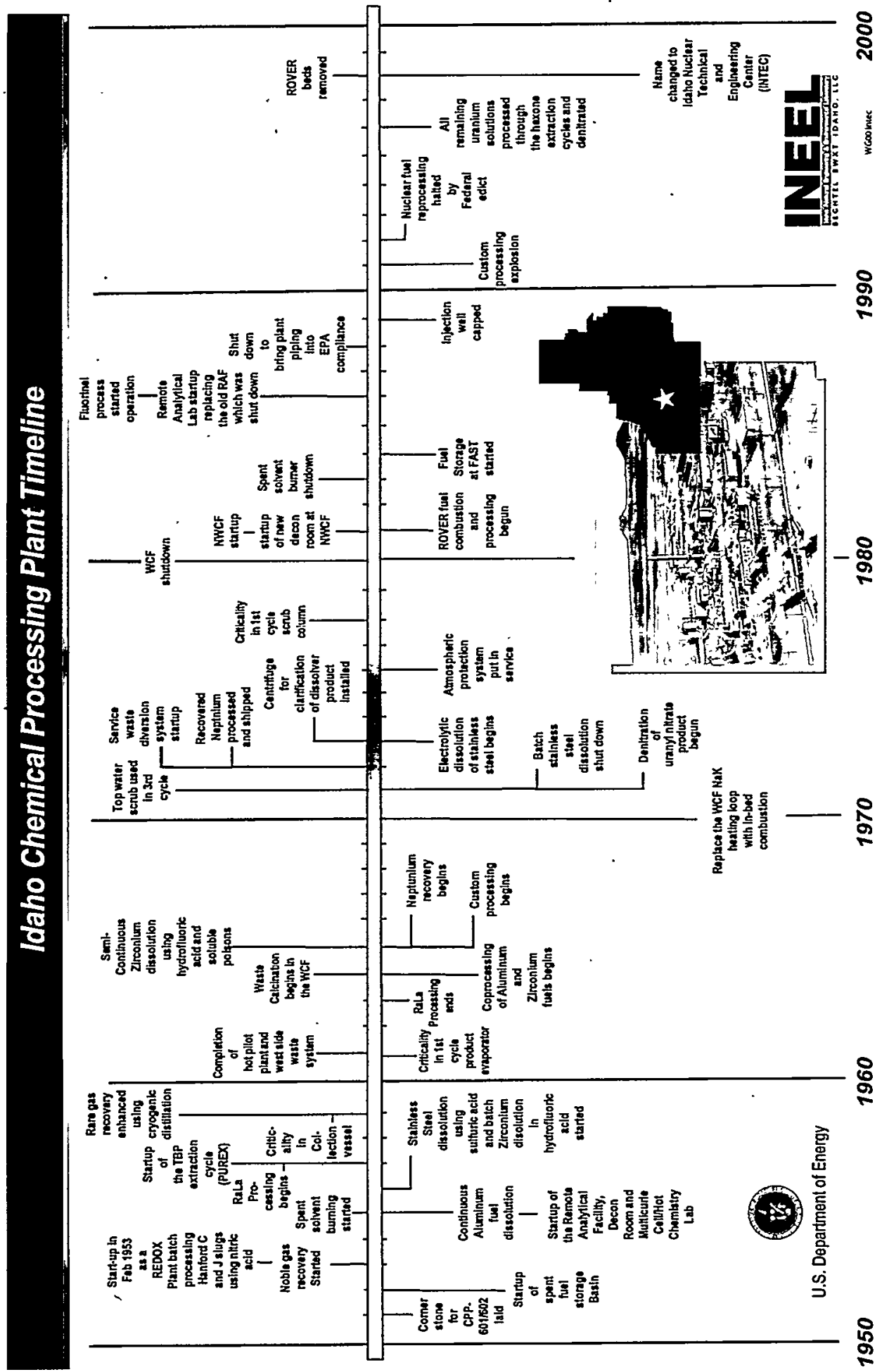




\subsubsection{Idaho Chemical Processing Plant}

\subsubsection{Plant Description}

The ICPP was originally built to process aluminum fuel from the Materials Test Reactor (MTR), unclad Experimental Breeder Reactor I (EBR-I) fuel, and Hanford neutron producing (NP) fuel using a methyl isobutyl ketone (hexone) extraction process. This process was used for the first seven processing campaigns. Dissolvers and extraction systems were all located in the CPP- 601 processing building. The extraction system that was common to all dissolution processes at that time consisted of three cycles of methyl isobutyl ketone extraction using stainless steel, Raschig ring packed columns with a thermosyphon evaporator at the beginning of each cycle, and a product evaporator at the end of the third cycle. Typically, uranyl nitrate solution was fed to each extraction cycle at a concentration of approximately 250 grams of uranium per liter. The final product was shipped at a concentration in excess of 250 grams per liter. Bottling, sampling, and product storage were carried out in rooms in the basement of CPP-602. The 10-liter polyethylene bottles were weighed on a large, double-pan balance, then put into birdcages for shipment. The dissolution and extraction process for aluminum fuel was carried out in CPP-601 from 1953 until the plant was shut down in 1992. Product packaging operations were performed in CPP-602 for all processes. Appendix A contains flowsheets for all of the processes described in this section. A block diagram of the processes used at ICPP is shown in Figure 3. 
Figure 3

FLOWSHEET OF PROCESSES USED AT ICPP

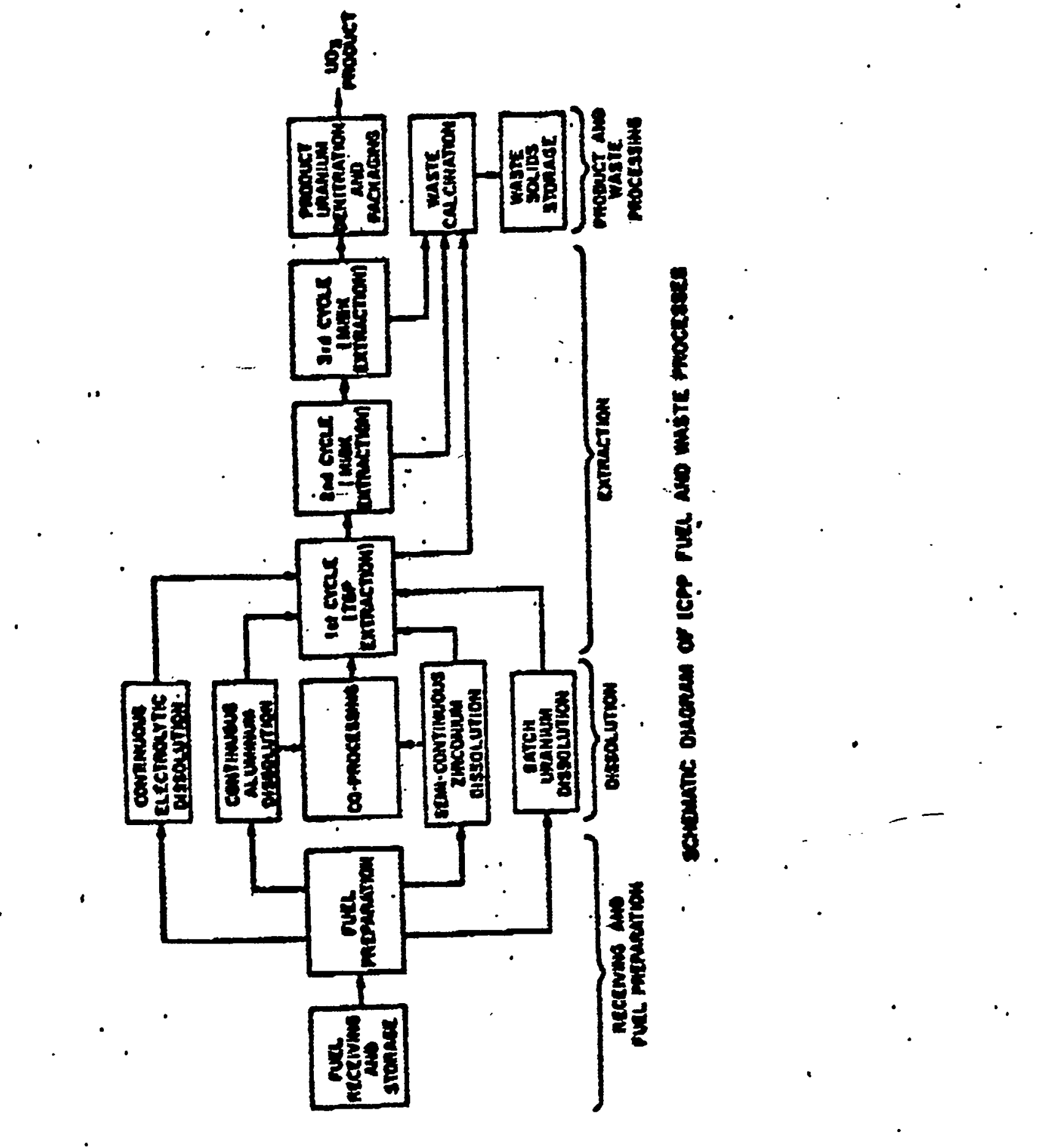


Processes for the dissolution of bare uranium slugs, declad EBR-I stainless fuel, aluminum clad fuel, batch dissolution of zirconium fuel, and the Radioactive Lanthanum ( $\mathrm{RaLa}$ ) process to recover radioactive barium from short cooled aluminum clad test reactor fuel were all started up during the first seven campaigns, process support modifications also took place. Analytical chemistry and process development laboratories went from standard 1950s style open bench-top laboratories with hoods to a Remote Analytical Facility (RAF) with shielded boxes utilizing castle manipulators and a development laboratory with RAF style boxes and a large process development cell with masterslave manipulators. Both of these modifications reduced exposure and risk of contamination. A large steel-lined room was also provided to decontaminate pieces of equipment used in the process facilities. These facilities were in CPP-627 until they were replaced with updated facilities in the 1980s. A process to remove the rare gases krypton and xenon from the dissolver off-gas using liquid nitrogen-cooled activated charcoal beds was also started up and operated. This process was located in CPP-604.

In 1955, the Continuous Processing Modification Project (CPM) was completed and a new high-capacity, first-cycle extraction system using tributyl phosphate dissolved in kerosene was placed into service. No preconcentration of the first cycle dissolver product was necessary, and the system could be operated concurrently with the fuel dissolvers. This system helped control criticality safety in the first cycle through the formation of stoichiometric compounds with the tributyl phosphate.

More modifications to the processes were made from 1957 to 1970. In 1958, the rare gas recovery plant was enhanced by replacing the carbon beds with a cryogenic distillation system. The recovery process for recovering radioactive barium was shut down in 1963. In 1964, the Waste Calcination Facility (CPP-633) was started hot to convert the high level wastes generated by the extraction columns and other radioactive liquid waste generating operations into a dry, granular waste form suitable for long-term storage. Custom processing in CPP-627 of small lots of odd fuel materials unsuitable for recovery anywhere else in the complex, semi-continuous zirconium dissolution in hydrofluoric acid containing a boric 
acid neutron poison for criticality safety, and the recovery of neptunium from the second cycle waste for use as an irradiation target started up in 1965. In 1970, the sodium-potassium eutectic alloy heating loop in the Waste Calcination Facility was removed from the calciner vessel and replaced with an inbed combustion system, which increased throughput and reduced nitrogen oxide and ruthenium emissions.

Two major innovations affected product and product shipments. The denitrator process in CPP-602 was started in 1971 with a fluidized bed thermal conversion process for converting uranyl nitrate to uranium trioxide. The entire process (denitration through product sampling and loadout) was enclosed in a glove box in the former uranyl nitrate bottling area of CPP-602 and operated until the process was shut down in 1996. Glove box operation minimized the potential for dust contamination to operating personnel.

A second innovation that also significantly affected the quality of the final product was put in service in 1971. This was a top water scrub that entered the top of the combination extraction/scrub column on the third extraction cycle (the second hexone extraction cycle). This scrub, whose original purpose was to reduce the amount of carryover of aluminum into the final product, also allowed the use of a second cycle for partitioning the higher actinides from the uranium since the iron from the ferrous ion reductant would not be carried over into the final product. This second partitioning cycle significantly reduced the amount of higher actinides in the product, as well as the carryover of fission products simply by removing entrained aqueous droplets being carried into the strip column by the organic product stream. In 1971, the batch, sulfuric acid, stainless steel dissolution headend was shut down.

In 1972, the neptunium that had been recovered from the second cycle partitioning step since 1965 was cleaned up using two cycles of hexone. The flow sheet used an acidic scrub rather than the normal acid deficient scrub to minimize losses of neptunium. Approximately $6.6 \mathrm{Kgs}$ of neptunium was shipped to the Savannah River Site for use as targets in making $\mathrm{Pu}-238$. The processing of neptunium was carried out in CPP601 . Bottling of the product was done in the multi-curie cell in CPP-627. 
In 1973, the electrolytic dissolver for the dissolution of the stainless steel clad EBR-II fuel was put in service in CPP-640. In conjunction with the electrolytic dissolver, a centrifuge for the clarification of the electrolytic dissolver product was also put in service. Dissolution of the EBR-II fuel resulted in small grains of stainless steel that did not dissolve and a significant quantity of finely divided fissium solids being present in the dissolver product. The centrifuge was essential to successful operation of the extraction process for the EBR-II fuel. The product from this process was a low burnup ( $\sim 2$ atom $\%)$, lower-enriched $\left(\sim 50 \%\right.$ enriched) $\mathrm{UO}_{3}$ than was normally seen in the product. This product ( 4.076 tonnes) was processed and packaged as a unique material and shipped directly to the Portsmouth Gaseous Diffusion Plant.

In 1981 the original Waste Calcination Facility (WCF) for processing high level waste was shut down for the last time. Decommissioning activities were completed and a concrete cap poured over the site in 1999. The New Waste Calcination Facility (NWCF) located in CPP-659, and a new decontamination room, built as a part of the NWCF to replace the original decontamination room in CPP-627, were started up in 1982. The new calciner featured a larger, fluidized-bed, calcination vessel for higher throughput and more remote maintenance capability for the remote replacement of failure prone equipment, which significantly reduced down time. It was shut down on May 26, 2000 pending permitting as an incinerator. There is currently approximately one million gallons of liquid waste left in storage at ICPP.

In 1983, the process for recovering uranium from the ROVER (Nuclear Rocket) fuel was started up. The ROVER fuel was a graphite rod with the uranium particles dispersed throughout the rod. The rods, which had been packaged in cardboard tubes, were burned in the primary burner. The ash from this burner was transferred to a secondary burner, where additional carbon was burned away prior to the ash being transferred to a leaching vessel. In the leaching vessels, the uranium was put into solution using a nitric/hydrofluoric acid mixture. It was extracted through the three cycles of extraction and then denitrated to $\mathrm{UO}_{3}$. Part of the product was shipped to Los Alamos for criticality studies and the rest was sent to $Y-12$. The fuel had a very low burn up $(\sim 0.1 \%)$ and, thus, did not 
have a significant buildup of either fission products or the actinides. This process operated for 14 months and was shut down. The fluidized bed burners have just recently been cleaned out.

In 1986, the Fluorinel Dissolution Process (FDP) was started up in CPP-666 to process zirconium-clad fuel. FDP had three large dissolvers that dissolved fuel in a mixture of hydrofluoric acid/aluminum nitrate, which had both boron and cadmium present as nuclear poisons. The Remote Analytical Laboratory (RAL) in CPP-684, was built to handle the sample load from the three FDP dissolvers, was started up in 1986. At the same time, the old Remote Analytical Facility (RAF) in CPP-627 was shut down. Replacing the RAF in total resulted in a significant reduction in radiation dose to the analytical personnel in the laboratory. In 1977, the radiation dose averaged approximately $500 \mathrm{mrem} /$ person who worked with radioactive samples in the labs and the maximum was 1.2 rem on one individual. The first full year in the new lab that was concurrent with a processing campaign (1987) the average exposure was $30 \mathrm{mrem} / \mathrm{person} / \mathrm{year}$ with the maximum about $300 \mathrm{mrem}$. However, in the ten-year period between 1977 and 1986 the average dose had slowly decreased as procedures, work practices, and equipment were changed. But, the largest decrease came with the new laboratory.

In 1988, the plant was temporarily shut down to bring the underground piping into compliance with EPA regulations. This entailed significant modifications throughout the processing facilities and the laboratories.

In 1991, the custom processing operation was shut down. In April 1992, an edict by then Secretary of Energy James Watkins halted all nuclear fuel reprocessing. The plant was, however, allowed to run the second and third cycle/denitration operation to completely remove all fissile material from the process tanks in 1996. That material and the material from the two Fluorinel campaigns is still stored in the CPP-651 vault.

In 1998, the ROVER beds were removed from the burners and uranium- containing materials from all of the other ROVER vessels was cleaned out. The ash is currently in dry storage at 
the CPP-603 Irradiated Fuel Storage Facility (IFSF) awaiting disposition decisions. More than $100 \mathrm{Kgs}$ of uranium is in this ash.

From 1953 until the recovery processes were finally shut down in 1996, all of the extraction processes, evaporative concentration processes, the product bottling, and the denitration process were operated in the CPP-601/CPP-602 buildings. Dissolution processes were operated in buildings CPP-601, CPP-640, and CPP-666. All of these processes were in heavily shielded cells in a totally remote operation. The dissolver system, the extraction systems, and the waste systems were all contact maintenance and depended upon extensive decontamination prior to cell entry. The liquid product bottling and the denitration product packaging operations were done in either a hood or a glove box, respectively. The flowsheets for all of the processes mentioned above, except for the waste processes, are shown in Appendix A.

\subsubsection{Material Flowsheet}

Spent fuel from reactors was originally received in CPP-603, which was a water filled storage basin. Other fuels were later received for dry storage in CPP-749 and eventually for dry storage in the IFSF an addition to CPP-603. In 1984, the water filled storage basin in the Fluorinel and Storage Facility (FAST), CPP-666, was started up and is currently storing spent fuel. The last fuel from the basins at CPP-603 was removed in May 2000 and the facility will soon be shut down and decommissioned.

After the decay of short-lived fission products including Iodine-131, the spent fuel from the storage basins at CPP-603 was transported to dissolvers in either CPP-602 or CPP-640. There, the fuel was dissolved in an acid specific to its particular cladding composition. Feed adjustments were made and the fuel was extracted initially in three hexone extraction cycles and later in a TBP/kerosene pulse column system followed by two cycles of hexone. The product from each extraction was concentrated by evaporation in a thermosyphon evaporator. The final product from the three extraction cycles was an aqueous solution of uranyl nitrate in nitric acid. After 1971, the uranyl nitrate solution was thermally decomposed in a 
fluidized bed denitrator and shipped as a solid $\mathrm{UO}_{3}$ granular product.

\subsubsection{Feed Specifications}

The feed to the ICPP was "as received" spent nuclear fuel. There were no acceptance criteria that determined whether the fuel was suitable for processing. In 1974, fuel receipt criteria were developed with a purpose of obtaining as much information on the fuel as possible to help understand the complexities associated with processing the fuel. Fuel could not be shipped until the receipt criteria response was provided, but responses to the questions would not prevent a fuel from being sent to ICPP.

\subsubsection{Product Specifications}

The early product specifications were informal and were subject to negotiation. A report by Egli, et. al. (Egli, 1985) suggested that a formal set of product specifications should be produced. This resulted in a letter (Foutch, 1985) from Y-12 to the managers of the plants at Savannah River and Idaho defining the specifications for the uranium product to be shipped to Y-12. These specifications defined the amount of alpha, beta, and gamma that could be in the product.

\subsubsection{Operating History}

The operating history of ICPP is detailed in Section 2.2.1.1.

\subsubsection{Current Status}

The process for recovering uranium from spent fuel is currently shut down. There is $1770 \mathrm{Kgs}$ of uranium product in storage at ICPP. There are also several hundred Kgs of spent fuel stored in dry storage in CPP-749, CPP-603 IFSF and in wet storage in the CPP-666 fuel storage basin.

\subsection{Activity Summaries}

The primary concentrating process at ICPP was the extraction cycles that removed the fission products, activation products, and actinides from the uranium and then concentrated both the uranium by evaporation and the fission product waste streams either by evaporation and/or calcination.

A second product concentration process took the concentrated uranyl nitrate stream and denitrated it to uranium trioxide. Any contaminants in these streams that were not volatile were concentrated by the denitration process. 
A third concentrating process was the ROVER burners. Graphite-based ROVER fuel was burned in fluidized bed burners resulting in an ash that contained uranium at a much higher concentration than was present in the fuel. A leaching process also may have resulted in a higher concentration.

Dissolution of the fuel in nitric acid could also result in a higher concentration per unit volume in the liquid phase than was present in the dry fuel state.

The above processes took place in remote equipment inside containment cells or boxes. Exposure to recycled uranium could occur after the product stream came out of the strip column in the last extraction cycle and was concentrated in an evaporator to $250 \mathrm{~g} / \mathrm{L}$ or more.

An examination of the tailend processes that occur after the concentration of the product have identified processes where workers can be exposed to contaminants in the recycled uranium product. These areas and activities are described in Table I. An "occupational exposure potential value" is also given in the table. The potential for worker occupational exposure is expressed as high, medium, low, or none in the "Occupational Exposure Potential" column. This value is derived from the product of three parameters qualitatively assigned by the specific Site Team. Each Site Team reviewed activities at their site that might have exposed workers to increased levels of the constituents and answered the following questions:

1) How much (high, medium, low, or none) airborne dust is generated by the activity?

2) What is the radiological hazard (high, medium, low, or none) of the material generated by the activity?

3) What is the length of time (long, medium, or short) a worker would be exposed to the airborne materials?

Each variable was assigned a value for each question and the values were multiplied together to determine the Occupational Exposure Potential. Activities associated with long-term exposure to high levels of dust with high radiological activity received the highest score while short duration activities in clean areas received the lowest score.

The list in the following table represents those areas and activities that the site team believes presents the highest potential for worker occupational exposure. 
Table I

ICPP Activity Chart

\begin{tabular}{|c|c|c|c|c|}
\hline Building & Activity & Time Frame & $\begin{array}{c}\text { Maximum } \\
\text { Constituents } \\
\text { Concentration } \\
\end{array}$ & $\begin{array}{c}\text { Occupational } \\
\text { Exposure } \\
\text { Potential } \\
\end{array}$ \\
\hline$\overline{\mathrm{CPP}-602}$ & $\begin{array}{l}\text { Bottling Liquid } \\
\text { Product in a Hood }\end{array}$ & $1953-1971$ & $\begin{array}{c}20 \% \mathrm{U}-236 \\
22 \mathrm{ppb} \mathrm{Pu} \\
1.6 \mathrm{ppm} \mathrm{Np}-237 \\
1.8 \mathrm{ppb} \mathrm{Tc}-99\end{array}$ & nil \\
\hline CPP-602 & $\begin{array}{l}\text { Packaging Solid } \\
\text { Product in a Glove } \\
\text { Box }\end{array}$ & $1971-1996$ & $\begin{array}{c}20 \% \text { U-236 } \\
22 \mathrm{ppb} \mathrm{Pu} \\
1.6 \mathrm{ppm} \mathrm{Np}-237 \\
1.8 \mathrm{ppb} \text { Tc-99 }\end{array}$ & nil \\
\hline $\begin{array}{l}\text { CPP-627 } \\
\text { CPP-602 }\end{array}$ & $\begin{array}{l}\text { Analysis of Liquid } \\
\text { Product }\end{array}$ & $1953-1996$ & $\begin{array}{c}20 \% \text { U-236 } \\
22 \mathrm{ppb} \mathrm{Pu} \\
1.6 \mathrm{ppm} \mathrm{Np}-237 \\
1.8 \mathrm{ppb} \mathrm{Tc}-99\end{array}$ & nil \\
\hline $\begin{array}{l}\text { CPP-627 } \\
\text { CPP-602 } \\
\text { CPP-684 } \\
\text { CPP-630 }\end{array}$ & $\begin{array}{l}\text { Analysis of Solid } \\
\text { Product }\end{array}$ & $1971-1996$ & $\begin{array}{c}20 \% \mathrm{U}-236 \\
22 \mathrm{ppb} \mathrm{Pu} \\
1.6 \mathrm{ppm} \mathrm{Np}-237 \\
1.8 \mathrm{ppb} \mathrm{Tc}-97\end{array}$ & $\mathrm{M}$ \\
\hline CPP-602 & Operating Denitrator & $1971-1996$ & $\begin{array}{c}20 \% \text { U-236 } \\
22 \mathrm{ppb} \mathrm{Pu} \\
1.6 \mathrm{ppm} \mathrm{Np}-237 \\
1.8 \mathrm{ppb} \mathrm{Tc}-97\end{array}$ & nil \\
\hline CPP-602 & $\begin{array}{l}\text { Maintenance on } \\
\text { Denitrator }\end{array}$ & $1971-1996$ & $\begin{array}{c}20 \% \mathrm{U}-236 \\
22 \mathrm{ppb} \mathrm{Pu} \\
1.6 \mathrm{ppm} \mathrm{Np}-237 \\
1.8 \mathrm{ppb} \mathrm{Tc}-97\end{array}$ & $\mathrm{M}$ \\
\hline СРP-602 & $\begin{array}{l}\text { Health Physics } \\
\text { Surveillance on } \\
\text { Denitrator }\end{array}$ & $1971-1996$ & $\begin{array}{c}20 \% \mathrm{U}-236 \\
22 \mathrm{ppb} \mathrm{Pu} \\
1.6 \mathrm{ppm} \mathrm{Np}-237 \\
1.8 \mathrm{ppb} \mathrm{Tc}-97\end{array}$ & $\mathrm{M}$ \\
\hline CPP-602 & $\begin{array}{l}\text { Health Physics } \\
\text { Surveillance of Liquid } \\
\text { Product Bottling }\end{array}$ & $1953-1996$ & $\begin{array}{c}20 \% \mathrm{U}-236 \\
22 \mathrm{ppb} \mathrm{Pu} \\
1.6 \mathrm{ppm} \mathrm{Np}-237 \\
1.8 \mathrm{ppb} \text { Tc-97 }\end{array}$ & nil \\
\hline
\end{tabular}




\subsubsection{Bottling Liquid Product}

Liquid product, which was concentrated uranyl nitrate solution in aqueous dilute nitric acid, was bottled out in a hood in the basement of CPP-602. The hoods were tested to have a face velocity of $125 \mathrm{ft}$. per second, which was enough to prevent alpha recoil particles from escaping. The product, being in solution, also reduced the risk of airborne particulate contamination making this a nil risk operation.

\subsubsection{Packaging Solid Product}

The solid product packaging operation was carried out in a glove box in close proximity to the denitrator vessel. The product was accumulated in a vessel near the denitrator. When this vessel contained enough $\mathrm{UO}_{3}$ to fill a shipping container, the $\mathrm{UO}_{3}$ was transferred to a V-blender, which mixed and homogenized the $\mathrm{UO}_{3}$ particles so that a representative sample could be obtained. The contents of the Vblender were then transferred to the shipping container. As the $\mathrm{UO}_{3}$ flowed into the container, samples were taken for accountability analyses. When the transfer was complete, the shipping container was weighed, sealed, and bagged out of the glove box along with the samples. The shipping container was then put into the shipping box used to maintain spacing for criticality control. This was the package that was shipped to the other sites. This activity is also a nil risk operation.

\subsubsection{Analysis of Liquid Product.}

Because the solid product analyses required handling a particulate sample during the transfers and during weighing of the aliquot, it presented slightly more risk than the liquid analytical procedures, even though all of the operations with the final product were carried out in a hood. This operation was also classified as a nil risk.

\subsubsection{Operating the Denitrator}

The workers operating the denitrator were protected by the glove box that contained the denitrator process. Accordingly, even though the operators were in attendance during the operation, the risk was classified as nil risk.

\subsubsection{Maintenance on the Denitrator}

Some maintenance operations are carried out in the glove box, but others required disassembly of the process equipment. At those times, there could be more particulate contamination than in any other operations. Personnel were required to were personal protective equipment during those operations for protection. This operation is a medium risk operation.

2.3.6 Health Physics Surveillance During Denitrator Operation Health Physics technicians monitor the radiation fields and air quality during denitrator operations. Their risk was essentially similar to those of themaintenance personnel and was classed as a medium risk. 


\subsubsection{Health Physics Monitoring During Liquid Product Bottling Health Physics technicians faced lower risks during liquid product handling operations than that faced for solid product operations. These operations were classed as medium risk operations.}

\subsection{Work Force Exposure}

All of the storage activities, processing activities, and waste processing activities were carried out in hot cells, so the radiation dose was carefully monitored and limited.

Exposure to the product was limited through either handling in hoods when the product was bottled out as liquid or in a glove box for the uranium trioxide solid product.

The dose to the work force was due primarily to maintenance activities, processing activities, health physics activities, and analytical chemistry activities in the early years. Radiation doses were less than the allowed $5 \mathrm{rem} / \mathrm{year}$. Subsequent to 1977 the practice was to limit dose to less than $3 \mathrm{rem} / \mathrm{year}$ to reduce the chance of challenging the $5 \mathrm{rem} / \mathrm{year}$ limit.

Analytical Laboratory dose in 1977 averaged $0.5 \mathrm{rem} /$ year beta/gamma on personnel who were actively analyzing radioactive samples. The maximum dose that year was 1.2 $\mathrm{rem} /$ year. In 1987, the dose averaged $0.03 \mathrm{rem} /$ year and the maximum was $0.1 \mathrm{rem} /$ year. The reduction was the result of operating in a state-of-the-art remote analytical laboratory whose first full year of operation coincided with a major high-burnup spent fuel campaign. Because of the construction of a new state-of-the-art spent fuel storage and dissolution facility and a new state-of-the-art calciner, similar reductions in the radiation dose were experienced on the operations and maintenance staff.

The shift workers were the personnel at the highest risk for contamination or radiation dose. A paper by Reid, D., et al. (Reid, 1961) in the Second Edition of the Reactor Handbook, Volume II presents some insight into the staffing levels and radiation work practices at ICPP during the late 1950s. The shift worker staff consisted of 29 operations, 27 maintenance, 14 analytical, and 9 radiation control personnel in a staff of 265 personnel. By contrast an equivalent staff during the 1987 FDP campaign consisted of 104 operations, 36 maintenance, 28 analytical and 24 health physics personnel in a staff of 1800 personnel.

Radiation dose limits were pushed harder in the early days prior to the "as low as reasonably achievable" (ALARA) policy, as evidenced by the following remark from the paper by D. Reid, in the Reactor Handbook:

It appears advantageous to utilize beta or gamma limits and to define such allowable limits over as long a period as practical. For example, a limit of an average of $5 \mathrm{rem} / \mathrm{yr}$ over a 10 -yr period is much more useful than $100 \mathrm{mrem} /$ week or 20 $\mathrm{mrem} /$ day. The problem of utilizing personnel to the best 
advantage under the limits is a serious one and takes planning, particularly in maintenance operations. For example, it is less advantageous to use a large number of men who will receive a very small exposure each than a smaller number of men receiving a larger individual exposure, since a significant fraction of the exposure will be received in setting set up to do the work before any useful maintenance is accomplished (page 648).

The quote seems to indicate that closely approaching maximum dose ( $5 \mathrm{rem} / \mathrm{year})$ was not unusual and might have been expected for every worker. By the middle of the 1970s, radiation doses were lower, but the ALARA policy had come into being resulting in an awareness of radiation and a sensitivity to unnecessary radiation dose. In the 1970s, a major cleanup of the plant took place that changed the radiation zone designations around the plant. Areas that had been controlled were cleaned and managed as uncontrolled areas.

Another paper by D. R. Wenzel, et. al. (Wenzel, 1980) discusses radiation dose experience at ICPP from 1973 to 1978. This period was chosen because prior to 1973, ICPP was managed by a contractor whose contract with AEC covered most of the facilities at the INEEL. As the result, these contractors had the ability to move personnel from one area to another, in part to spread out contamination and in part to provide other opportunities for the personnel. However, this practice had the effect of making it very difficult to differentiate exposures that occurred at ICPP from those that occurred at the reactors or at the waste sites.

Wenzel's paper tracks production, maintenance, and health physics wherein analytical personnel were lumped in with the total plant personnel. During this time, the total plant dose varied from as little as 300 rem to as high as 680 rems Also, during this time, the monitored radiation worker population at the plant went from 600 to 1400 people. However, the change in production, maintenance, and health physics personnel was less than $10 \%$ from 230 to 290 people. During this same period, the average dose for health physics personnel was between $2.7 \mathrm{rem}$ and $1.8 \mathrm{rem}$ and was consistently about $1.2 \mathrm{rem}$ through the 6 year period for both maintenance and production personnel.

During the period from 1973 to 1978 , the total plant dose went from 375 rem to $640 \mathrm{rem}$. However, the demographics of the plant also changed. In 1975, a dedicated construction work force was used at ICPP. This increased the average dose of the construction workers at ICPP because of the smaller number of workers used on a larger number of radiation jobs. From 1976 to 1978 , the construction work force was approximately equal to the total maintenance, operations, and health physics workforce. In 1973, all other radiation workers received a total of $105 \mathrm{rem}$ in 1973. By 1978, this had reduced to 69 rem for these 
same "other" classifications. These classifications included management, technical, analytical, engineering and quality assurance.

The internal dosimetry program during this period consisted of whole body counts given annually to radiation workers. For personnel where internal contamination was suspected, formal dose assessments were made for cases where the calculated "fifty-year dose commitment" exceeded $10 \%$ of the radiation protection standard for any critical organ. Typically, the dose commitment levels were small fractions of the permitted limit of 15 rem per year, the total cumulative lung dose for any worker had not exceeded $8 \mathrm{rem} / \mathrm{year}$, and the total for all workers has not exceeded $32 \mathrm{rem}$ in a single year. The limiting internal contaminant had

been Ce-144.

In 1976, an administrative guideline of 3 rem per year was adopted that required special management approval to exceed this guideline. Administering this guideline required rapid processing of dosimeters with the up-to-date cumulative dose data managed on a computer. Access to the data by health physics personnel enabled them to control the dose from the field. Management was also alerted when any one individual began to approach the 3 rem guideline. Management of the work and the personnel was critical to maintaining cumulative exposure to less than the $3 \mathrm{rem}$.

In 1978, the dose equivalent for the total regular employee at ICPP indicated that no one had exceeded $4 \mathrm{rem}$ that year, although there were 14 individuals between 3 and $4 \mathrm{rem}$. There were 67 people between 2 and $3 \mathrm{rem}, 95$ people between 1 and $2 \mathrm{rem}$, and 342 people who received a dose exposure greater than the minimum detectable amount up to 1 rem. There were also 430 people out of the total 948 total employees who received less than a detectable radiation dose. Radiation workers who received more than a detectable amount of radiation during 1978 were approximately 518 people.

A final note on radiation doses occurred in 1995 when the contractor at that time offered an early retirement incentive to employees 55 years of age or older. Approximately 350 people from the ICPP out of approximately 1800 total employees took advantage of the early retirement incentive. The effect on the cumulative radiation dose, however, was that slightly more than $50 \%$ of the cumulative radiation dose left with those retirees. An additional effect that this retirement offer had on the cumulative radiation dose was to significantly reduce the average dose per person by removing from the work force population, the "old timers" who had accumulated large doses at a time when the normal operating mode was to push the maximum annual dose limit.

An assessment of the relative risk to an individual handling ICPP product can be made using the data from the ORIGEN2 calculations for the three typical fuels processed at ICPP. The radionuclide distribution data was then entered into the RSAC- 5 computer program to evaluate the relative amount of internal dose from each of the radionuclides. 
An assumption was made that the transuranic alpha in the final product was 5000 disintegrations/minute (dpm) per gram of total uranium. A further assumption was made that the isotopic distribution of uranium did not change from the ORIGEN2 calculated values as the uranium was processed through the ICPP extraction systems. Still further, an assumption was made that the isotopic distribution of the plutonium did not change while processing and that the ratio of both neptunium-237 and technetium-99 to plutonium is the same as it is in the dissolver product.

Other assumptions were made to make the model fit the situation since the model the computer code uses is an airborne inhalation model. A rate of $3.33 \times 10^{-4}$ cubic meters/second $\left(\mathrm{m}^{3} / \mathrm{s}\right)$ was assumed for the breathing rate for an individual and an internal dose was assumed to occur over a 50 year time period. A particle size of 1.0 microns activity median acrodynamic diameter (AMAD) was assumed. The lung clearance class for this calculation is shown in Table II.

\section{Table II}

\section{Lung Clearance Classes Used to Determine the Relative Hazard from Various Isotopes}

$\begin{array}{lccccccccc}\text { Element } & \mathrm{U} & \mathrm{Np} & \mathrm{Pu} & \mathrm{Th} & \mathrm{Am} & \mathrm{Pa} & \mathrm{Ra} & \mathrm{Pb} & \mathrm{Tc} \\ \text { Lung Clearance Class } & \mathrm{Y} & \mathrm{W} & \mathrm{Y} & \mathrm{Y} & \mathrm{W} & \mathrm{Y} & \mathrm{W} & \mathrm{D} & \text { W }\end{array}$

Using these assumptions, the program calculated the committed effective dose equivalent (CEDE) for each radionuclide and its percent contribution to the total inhalation. This data is shown in Table III.

As can be seen from the Table $\mathrm{II}$, the risk from inhalation is due primarily to the uranium isotopes at $5000 \mathrm{dpm}$ transuranic alpha per gram of uranium. The plutonium isotopes have a risk on the order of the $10^{-3} \%$ while the sum of the uranium isotopes have in excess of $99.9 \%$ of the risk. Both neptunium-237 and technetium-99 are on the order of less than $10^{-17} \%$ of the dose.

Because, this analysis was done using the maximum transuranic (TRU) activity allowed by the alpha specification ( $5000 \mathrm{dpm}$ TRU/gram U), the actual percent of the dose from the actinides, $\mathrm{Pu}$ and $\mathrm{Np}$ will be actually less than indicated in Table III. For the product from aluminum and stainless steel processing, U-234 is the most limiting radionuclide. U-235, however, is the limiting radionuclide from the zirconium process. The potential dose from plutonium is more than three orders of magnitude less than from the dose from uranium. The dose from neptunium and technetium is insignificant compared to that from uranium.

The plutonium isotope that contributes the highest potential dose from inhalation of uranium product is $\mathrm{Pu}-238$ for the zirconium and aluminum fuel processing and $\mathrm{Pu}-239$ for stainless steel processing. However, the potential Pu-239 dose from the product of stainless steel processing is less than $0.02 \%$ of the dose from uranium. 
Table III

Comparative Risk and Effective Dose Equivalent for Isotopes in the Product from Processing at ICPP.

Isotope

$\mathrm{U}-232$

U-233

U-234

U-235

U-236

U-238

Pu-238

Pu-239

Pu-240

Pu-241

Pu-242

Np-237

Tc-99

Total EDE (rem) Percent Aluminum

$\begin{array}{ll}1.72 \mathrm{E}-7 & 3.82 \mathrm{E}-1 \\ 4.18 \mathrm{E}-10 & 9.29 \mathrm{E}-4 \\ 4.03 \mathrm{E}-5 & 8.96 \mathrm{E}+1 \\ 7.80 \mathrm{E}-7 & 1.74 \mathrm{E}+0 \\ 3.72 \mathrm{E}-6 & 8.27 \mathrm{E}+0 \\ 1.24 \mathrm{E}-8 & 2.76 \mathrm{E}-2\end{array}$

6.10 E-10

9.59 E-12

$1.36 \mathrm{E}-3$

2.13 E-5

$1.28 \mathrm{E}-5$

8.29 E-5

$2.60 \mathrm{E}-8$

1.17 E-14

$<$ E-22

$<$ E-22

$<\mathrm{E}-17$

$<$ E-17

4.5 E-5 rem

\begin{tabular}{|c|c|}
\hline \multirow{2}{*}{\multicolumn{2}{|c|}{$\underset{\text { Zirconium }}{\operatorname{EDE}(\text { rem) }}$}} \\
\hline & \\
\hline $6.92 \mathrm{E}-7$ & $8.90 \mathrm{E}+0$ \\
\hline 1.29 E-10 & $1.66 \mathrm{E}-3$ \\
\hline $3.28 \mathrm{E}-7$ & $4.22 \mathrm{E}+0$ \\
\hline $7.80 \mathrm{E}-7$ & $1.00 \mathrm{E}+1$ \\
\hline 5.97 E-6 & $7.68 \mathrm{E}+1$ \\
\hline 2.57 E-9 & 3.31 E-2 \\
\hline
\end{tabular}

2.63 E-9

1.53 E-12

1.20 E-12

2.08 E-12

6.46 E-16

$<$ E-22

$<$ E-22

7.77 E-6 rem

3.38 E-2

1.96 E-5

1.55 E-5

2.68 E-5

8.54 E-9

$<$ E-15

$<$ E-15

$99.9 \%$
EDE Stainless Steel

Percent

$\begin{array}{ll}1.59 \mathrm{E}-8 & 9.29 \mathrm{E}-2 \\ 1.19 \mathrm{E}-10 & 6.98 \mathrm{E}-4 \\ 1.64 \mathrm{E}-5 & 9.59 \mathrm{E}+1 \\ 5.05 \mathrm{E}-7 & 2.95 \mathrm{E}+1 \\ 1.01 \mathrm{E}-7 & 5.90 \mathrm{E}-1 \\ 7.34 \mathrm{E}-8 & 4.29 \mathrm{E}-1\end{array}$

$<$ E-23

$<$ E-17

$<$ E-23

$<$ E-17

6.53 E-11 3.81 E-4

2.91 E-9 $1.70 \mathrm{E}-2$

2.16 E-11 1.26 E-4

5.22 E-19 3.05 E-12

1.71 E-5 rem $\quad 100.0 \%$
2.20 E-13 1.29 E-6 
In the 1980s, a fecal sampling program was added to routine urine sampling that had been in place since the 1950s. The early fecal sampling that started in 1980 identified internal contamination in analytical laboratory personnel that was traced to a bad hood and hot cell ventilation system. Occasional internal contamination incidents have occurred through the years with radiation doses at levels slightly above background.

\subsection{Environmental Releases}

The INEEL Historical Dose Evaluation report, Volume I, (INEEL, 1991) attempted to determine the off-site dose that resulted from activities at the site. The site has released radionuclides through injection wells at the facilities since each individual facility started up. Radionuclides were never discharged in the surface waters such as the Big Lost River or Little Lost River. The practice of injecting waste water deep under-ground was stopped in 1984 with the closure and sealing of the ICPP injection well.

Radionuclide migration has been tracked through sampling the water in wells drilled into the aquifer all over the site. Two radionuclides are of particular interest, tritium, because it is a component of the water molecule and chlorine-36, because of its high solubility as the chloride ion and its long half-life $\left(3.0 \times 10^{5}\right.$ years). Chlorine- 36 has been detected at the site boundary, but at levels that are one-millionth of the amount permitted by the EPA in community drinking water. Tritium has also been detected at wells at the site boundary, but has not been found in any off-site wells. Neither of these radionuclides has contributed any significant dose to any member of the public as the result of activities at the site by this route. In addition to tritium and chlorine-36, other radioactive elements such as plutonium, cesium, and strontium, were also considered but were found to absorb on the soils.

Some biotic pathways also exist, the most important being through big game animals that ingest water or plants contaminated with radionuclides and then migrate off site. Through a literature search on this pathway the dose reconstruction group concluded that this was a highly unlikely source of radiation exposure and could result in a dose as high as $10 \mathrm{mrem} / \mathrm{hr}$.

In their assessment, the airborne pathway is the principal pathway for release of radionuclides to the public. Releases from the site were broken into two classes: operational releases and episodic releases. Operational releases are continuous releases that extend over the length of operating periods while episodic releases are the result of experiments, tests, or accidents and are typically short in duration and treated as distinct events.

Annual site releases varied from less than $10,000 \mathrm{Ci}$ to as high as 1.5 million $\mathrm{Ci}$ released in 1961. Most of the activity was short lived consisting of noble gases and their particulate daughter products. This covered the forty year time period 
from 1951 through 1990. Operational site releases peaked from 1957 to 1959 and have declined by approximately two orders of magnitude through 1989 . The episodic dose contribution was less than 1\%, except between 1955 through 1961. During the entire forty year period that the dose reconstruction report covers, there have only been two ICPP events that contributed more than $0.1 \mathrm{mrem}$ to the annual dose. These two events were the criticality accident that took place on October 16, 1959 and the fuel element cutting facility (FECF) filter break that occurred on October 29-30, 1958.

The effective dose equivalent (EDE) from the FECF filter break for an adult, child, and infant was $0.11,0.12$, and $0.12 \mathrm{mrem}$, respectively. The maximum organ dose (to the skin) was 1.4 mrem irrespective of age. The EDE for the 1959 criticality event for an adult, child, and infant was 1.1, 1.2 and $1.5 \mathrm{mrem}$, respectively; and the thyroid dose, which was the maximum organ dose, for the adult, child and infant was 6,9 , and 22 mrem. These dose estimates were based on the assumption that the people were living on the boundary of the site full time.

The period when the operational dose from the ICPP was contributing a significant amount to the off-site dose was during the early years of the RaLa process - specifically between 1957 and 1959. During those years the EDE was predominantly due to I-131, which was released during RaLa processing of fresh fuel to recover the short-lived barium-140. By 1959, the off-gas tank for delaying the release off-gas from the dissolution until the I-131 decayed, was in place and had reduced I-131 emissions that year by a factor of two.

In spite of the various episodic releases and the operational releases, there has not been any year in the history of the INEEL site that the radiation doses exceeded the applicable public dose standards in place during that year. During the late 1950 s, the EDE may have been as high as $9 \%$ of the whole body dose standard and as high as $90 \%$ of the organ dose standard. During the more recent years, when more restrictive standards have been in place, the off-site dose to the maximally exposed person has been less than $1 \%$ of the whole body standard and less than $3 \%$ of the organ dose standard. These doses are insignificant when compared to the natural background doses for a person living on the Snake River Plain. The natural background is about $350 \mathrm{mrem} / \mathrm{yr}$ due to terrestrial, cosmic, naturally occurring radionuclides and radon sources. The maximum EDE occurring in 1956 from airborne releases at the INEEL was $17 \%$ of the natural background level. Since the 1970s, the doses have been very small, even compared to the variability of the natural background from year to year and from location to location in Eastern Idaho. 


\subsection{Uranium Recycle Description}

The ICPP received spent fuel from propulsion reactors, DOE test reactors, foreign reactors under the Atoms for Peace Program, and from university reactors. The burnup on these fuel materials ranged from zero (or very low burnup) to high burnups on some of the reactor development fuel. The reactor fuels were primarily from light water reactors but included fast breeder reactor fuels as well. The beginning of life enrichment of the fuels processed ranged from $50 \%$ to $97 \%$. The average end-of-life enrichment for the non-classified fuels was approximately $78 \%$.

After the uranium was recovered by the ICPP processes, the fuel was shipped to Y-12 or Portsmouth for additional processing and for recycling into the complex inventory or it was shipped to Rocky Flats, Pacific Northwest National Laboratory, or Los Alamos National Laboratory where it was used for criticality experiments in their physics program.

\subsection{Uranium Receipts}

Recycled uranium was received at ICPP from Y-12 in 1971 in the form of $\mathrm{UO}_{3}$ prepared in their rotary kiln denitrator. This material was used for the startup bed for the denitrator to begin processing the $50 \%$ enriched uranium product. The amount of uranium received was $20.648 \mathrm{Kgs}$ and was shipped to out with the first batch of denitrated uranium product. Details on the contaminants in this material are unknown although it is believed to be material that had been shipped to Y-12 from ICPP then run through their process to make the particulate $\mathrm{UO}_{3}$ needed for the initial denitrator bed.

A second shipment was received in 1978. It was a partial return of the material that had been shipped to PNNL for criticality experiments earlier in 1978 and consisted of $28.064 \mathrm{Kgs}$ of recycled uranium. It was returned to the process inventory, run through the hexone extraction cycles, then denitrated before being shipped out with similar product to Y-12. This material is the product that ICPP shipped to PNNL and as such the contaminants would be identical to the contaminants that were shipped.

\subsection{Uranium Shipments}

Uranium shipments from ICPP are shown in Table IV. The products were shipped to the Y-12 plant (24,773 Kgs) for purification and preparation of metal for use as driver fuel for the Savannah River production reactors. $4,076 \mathrm{Kgs}$ were sent to Portsmouth for re-enrichment and recycling into the DOE complex reactors. In addition, small quantities were shipped to other complex sites for use in criticality experiments: $47 \mathrm{Kgs}$ to the Pacific Northwest National Laboratory, 
$168 \mathrm{Kgs}$ to Los Alamos National Laboratory, and $219 \mathrm{Kgs}$ to Rocky Flats. Shipping data giving dates and locations where the shipment was sent are also shown in Table IV.

The listing of fuel processed at ICPP, (see Table V) is based on the spent fuel shipper data, which is the as-fabricated (or "before burnup") value. This value was deliberately chosen for the input value because of criticality concerns. "Burnup" of specific fuel elements in a core is a function of their location in the core. By using the "before burnup" value for the uranium, a credible, conservative assessment of criticality risk can be made. Once the fuel is in solution, an accurate measurement of the uranium and the fissile content can be made.

The accountability tank is where the samples are taken for the input accountability measurements. These values are then used through the rest of the process as the basis for the criticality calculations.

The final accountability measurement is made after the uranium passes through all of the extraction cycles and the final product is packaged. Samples are then taken from each of the shipping containers. The measurements made on each of the samples is an isotope dilution mass spectrometry measurement where an accurately measured aliquot containing a precisely known amount of U-233 is added to the sample as a calibration standard. This method provides accurate and highly precise values of total uranium and uranium isotopic distribution.

The initial input values provided by the shipper do not take into account the U-235 consumed by the reactor. As a result, the amount of total uranium in the final product, (see Table IV), would be expected to be less than that charged to the dissolvers, as shown in Table $\mathrm{V}$. Thus, the excess that is observed is the difference between the shippers values recorded as the material was charged to the dissolvers and the amounts measured at the point where the product packages were sealed for shipment. 
Table IV

Shipments of Final Product

\begin{tabular}{|c|c|c|c|c|}
\hline Year & 741 & No. Shipments & Destination & Total U \\
\hline$\overline{1953}$ & CPI-CYT & 8 & $\mathrm{Y}-12$ & $310,983 \mathrm{~g}$ \\
\hline 1954 & CPI-CYT & 7 & $\mathrm{Y}-12$ & $289,247^{\circ}$ \\
\hline \multirow[t]{2}{*}{1955} & (CPI-CYT & 8 & $742,669)$ & \\
\hline & (CPI-SFJ & 3 & Rocky Flats 219,093 ) & 961,762 \\
\hline 1956 & CPI-CYT & 7 & Y-12 & $1,122,452$ \\
\hline 1957 & CPI-CYT & 5 & Y-12 & 611,851 \\
\hline 1958 & CPI-CYT & 9 & Y-12 & $2,683,680$ \\
\hline 1959 & CPI-CYT & 5 & Y-12 & $1,763,087$ \\
\hline 1960 & CPI-CYT & 3 & $\mathrm{Y}-12$ & 579,649 \\
\hline 1961 & - & - & - & - \\
\hline 1962 & CPI-CYT & 8 & $\mathrm{Y}-12$ & 775,823 \\
\hline 1963 & CPI-CYT & 3 & $\mathrm{Y}-12$ & 770,678 \\
\hline 1964 & JZA-FZB & 2 & $\mathrm{Y}-12$ & 421,818 \\
\hline 1965 & JZA-FZB & 4 & Y-12 & 812,790 \\
\hline 1966 & JZA-FZB & 3 & $\mathrm{Y}-12$ & 595,477 \\
\hline 1967 & - & - & - & - \\
\hline 1968 & JWA-FZB & 4 & $\mathrm{Y}-12$ & 821,403 \\
\hline 1969 & - & - & - & - \\
\hline 1970 & JWA-FZB & 4 & Y-12 & 527,383 \\
\hline \multirow[t]{2}{*}{1971} & (JWA-FZB & 2 & $Y-12)$ & $1,654,977$ \\
\hline & (JSA-FZB & 2 & $Y-12)$ & \\
\hline 1972 & JSA-FZB & 1 & Y-12 & 434,476 \\
\hline \multirow[t]{2}{*}{1973} & (JSA-FXA & 4 & Portsmouth $1,374,895$ ) & \\
\hline & (JSA-FZB & 2 & $552,835)$ & $1,927,730$ \\
\hline 1974 & JSA-FZB & 1 & $\mathrm{Y}-12$ & 381,339 \\
\hline \multirow[t]{2}{*}{1975} & (JSA-FZB & 2 & $898,009)$ & \\
\hline & (JSA-FXA & 3 & Portsmouth $1,402,663$ ) & $2,300,672$ \\
\hline \multirow[t]{2}{*}{1976} & (JSA-FXA & 3 & Portsmouth $1,298,210$ ) & \\
\hline & (JSA-FZB & 2 & $519,582)$ & $1,817,792$ \\
\hline 1977 & JSA-FZB & 2 & $\mathrm{Y}-12$ & 976,177 \\
\hline \multirow[t]{2}{*}{1978} & (JSA-FZB & 3 & $526,966)$ & \\
\hline & (JSA-HYA & 2 & $47,010)$ & 573,976 \\
\hline 1979 & JSA-FZB & 1 & $\mathrm{Y}-12$ & 543,976 \\
\hline 1980 & - & - & - & - \\
\hline 1981 & JXI-FZB & 2 & $\mathrm{Y}-12$ & 904,422 \\
\hline 1982 & JXI-FZB & 2 & $\mathrm{Y}-12$ & $1,102,135$ \\
\hline 1983 & JXI-FZB & 2 & Y-12 & 517,913 \\
\hline \multirow[t]{3}{*}{1984} & (JXI-FZF) & & & \\
\hline & (JXI-FZB & 11 & $2,868,215)$ & \\
\hline & (JXI-AUA & 3 & $167,606)$ & $3,035,821$ \\
\hline 1985 & - & - & - & - \\
\hline 1986 & JXI-FZF & 4 & Y-12 & 955,115 \\
\hline 1987 & - & & & \\
\hline 1988 & - & & & \\
\hline 1989 & - & & & \\
\hline 1990 & - & & & \\
\hline 1991 & - & & & \\
\hline 1992 & - & & & \\
\hline 1993 & JXI-FZF & 1 & $\mathrm{Y}-12$ & 116,496 \\
\hline $1994-1997$ & - & - & - & - \\
\hline 1998 & JXI-FZF & 2 & $Y-12$ & 424 \\
\hline \multicolumn{3}{|c|}{ Product inventory currently stored at INEEL } & $1,770,061$ & \\
\hline
\end{tabular}




\section{Table V}

Fuel Processed at ICPP

Number Date Fuel Type

U Kgs Process

Total U Kgs

\begin{tabular}{|c|c|c|c|c|c|}
\hline 1. & $2 / 53-8 / 53$ & Hanford C and J Slugs & 275.33 & Aluminum & 275.33 \\
\hline 2. & $10 / 53-12 / 53$ & $\begin{array}{l}\text { MTR, LITR, NRX Aluminum Clad, Declad } \\
\text { EBR-I in Aluminum Can }\end{array}$ & 65.95 & Aluminum & 65.95 \\
\hline 3. & $7 / 54-2 / 55$ & $\begin{array}{l}\text { Declad EBR-I in Al can. NPR, MTR, LITR, } \\
\text { Borax, Hanford C and J Slugs }\end{array}$ & 645.35 & Aluminum & 645.35 \\
\hline 4. & $3 / 55-11 / 55$ & $\begin{array}{l}\text { Hanford J Slugs, MTR, Borax, LITR, SRP } \\
\text { Reject Slugs }\end{array}$ & 667.34 & Aluminum & 667.34 \\
\hline 5. & $12 / 55-3 / 56$ & Hanford C and J Slugs, SRP Reject Slugs & 581.13 & Aluminum & 581.13 \\
\hline 6. & $3 / 56-5 / 56$ & MTR, LITR, CP-3, CR, Borax & 30.83 & Aluminum & 30.83 \\
\hline \multirow[t]{3}{*}{7.} & $5 / 56-3 / 57$ & $\begin{array}{l}\text { Hanford C and J Slugs, CR, MTR, Borax, } \\
\text { LITR, ANL, SRP LM Slugs }\end{array}$ & 956.20 & Aluminum & 970.38 \\
\hline & & Zirconium & 11.57 & Zirconium & \\
\hline & & RaLa MTR & 2.61 & RaLa & \\
\hline \multirow[t]{2}{*}{8.} & $10 / 57-12 / 57$ & SRP LM Slugs & 467.00 & Aluminum & 467.20 \\
\hline & & RaLA MTR & 0.20 & RaLa & \\
\hline 9. & $12 / 57-1 / 58$ & Zirconium & 15.00 & Zirconium & 15.00 \\
\hline \multirow[t]{2}{*}{10.} & $1 / 58-2 / 58$ & Hanford C Slugs & 276.50 & Aluminum & 277.20 \\
\hline & & RaLa MTR & 0.70 & $\mathrm{RaLa}$ & \\
\hline
\end{tabular}


Table V

Fuel Processed at ICPP

$\begin{array}{lllll}\text { Number Date } & \text { Fuel Type } & \text { U Kgs } & \text { Process } & \text { Total U Kgs }\end{array}$

\begin{tabular}{|c|c|c|c|c|c|}
\hline 11. & $5 / 58-11 / 58$ & $\begin{array}{l}\text { SRP LM Slugs, SRP Tubes, MTR, Chalk } \\
\text { River }\end{array}$ & 2226.53 & Aluminum & 2228.70 \\
\hline & & RaLa MTR & 2.17 & $\mathrm{RaLa}$ & \\
\hline \multirow[t]{2}{*}{12.} & $12 / 58-4 / 59$ & SRP Slugs, SRP Tube, NRX & 653.15 & Aluminum & 653.99 \\
\hline & & RaLa MTR & 0.84 & RaLa & \\
\hline 13. & $4 / 59-8 / 59$ & $\begin{array}{l}\text { SRP Tube, SRP Slugs, SRP Tube Ends, } \\
\text { Chalk River }\end{array}$ & 1174.60 & Aluminum & 1174.60 \\
\hline \multirow[t]{3}{*}{14.} & $7 / 59-12 / 59$ & Zirconium & 58.30 & Zirconium & 88.64 \\
\hline & & OMRE, BMI & 28.50 & Aluminum & \\
\hline & & RaLa MTR & 1.84 & RaLa & \\
\hline \multirow[t]{2}{*}{15.} & $12 / 59-2 / 60$ & $\begin{array}{l}\text { MTR, ETR, LITR, Convair (ASTR), Hanford } \\
\text { C, J and KW Slugs, SRP LM Slugs }\end{array}$ & 779.90 & Aluminum & 780.23 \\
\hline & & RaLa MTR & 0.33 & RaLa & \\
\hline \multirow[t]{2}{*}{16.} & $2 / 60-3 / 60$ & Zirconium & 48.00 & Zirconium & 48.50 \\
\hline & & RaLa MTR & 0.50 & RaLa & \\
\hline \multirow[t]{2}{*}{17.} & $3 / 60-4 / 60$ & Zirconium & 27.00 & Zirconium & 27.17 \\
\hline & & RaLa MTR & 0.17 & RaLa & \\
\hline 18. & $1 / 61-2 / 61$ & ETR & 45.10 & Aluminum & 45.10 \\
\hline
\end{tabular}


Table V

Fuel Processed at ICPP

Number Date Fuel Type

U Kgs

Process

Total U Kgs

\begin{tabular}{|c|c|c|c|c|c|}
\hline 19. & $12 / 61-2 / 62$ & $\begin{array}{l}\text { MTR, ETR, Borax IV, Hanford C and J } \\
\text { Slugs, LITR, Chalk River, CP-5, LPTR, } \\
\text { Convair (GTR), OWR, SL-1 Scrap }\end{array}$ & 647.38 & Aluminum & 651.89 \\
\hline & & RaLa, MTR & 4.51 & RaLa & \\
\hline \multirow[t]{2}{*}{20.} & $6 / 63-9 / 63$ & $\begin{array}{l}\text { MTR, ETR, SPERT, GETR, BRR, SL-1, } \\
\text { BNL, LITR, CP-5, LPTR, Convair (GTR), } \\
\text { OWR, WTR, Borax III, Suzie, Hanford AEC } \\
\text { and REY, NRU }\end{array}$ & 757.25 & Aluminum & 758.92 \\
\hline & & RaLa MTR & 1.67 & $\mathrm{RaLa}$ & \\
\hline \multirow[t]{2}{*}{21.} & $6 / 64-12 / 64$ & $\begin{array}{l}\text { BGRR, NRX, McMasters, NRU, NRL, SWE, } \\
\text { RL, U of Mich, FNR, GTR, MTR, OWR, } \\
\text { LPTR, LITR UF, ETR, CP-5, Zirconium, } \\
\text { SPERT NASA, }\end{array}$ & $\begin{array}{c}504.69 \\
\\
\quad:\end{array}$ & $\begin{array}{l}\text { Co-processing } \\
\text { Aluminum/Custom }\end{array}$ & 1228.53 \\
\hline & & $\begin{array}{l}\text { Zr Scrap, PWR Core 1/Seed 1, Zr EBR-I } \\
\text { Core 3, SNAPTRAN } 2 / 10 A-3 \text { Core Debris }\end{array}$ & 723.84 & $\begin{array}{l}\text { Co-processing } \\
\text { Zirconium }\end{array}$ & \\
\hline 22. & $4 / 65-6 / 65$ & VBWR, $\mathrm{AI} \mathrm{UO} \mathrm{SO}_{4}$ & 44.60 & Aluminum/Custom & 44.60 \\
\hline 23. & $12 / 65-1 / 66$ & $\begin{array}{l}\text { ATR, MTR, ETR, SPERT, LITR, LPTR, } \\
\text { OWR, GTR, ASTR, GETR, EBR-II } \\
\text { Vycor Glass Molds, EBR-I Mark II, Plastic } \\
\text { Coated Al Fuel Plates }\end{array}$ & 526.96 & Aluminum/Custom & 526.96 \\
\hline
\end{tabular}


Table V

Fuel Processed at ICPP

Number Date Fuel Type

U Kgs Process

Total U Kgs

\begin{tabular}{|c|c|c|c|c|c|}
\hline 24. & $3 / 67-9 / 67$ & $\begin{array}{l}\text { JRR-2/Core 1, NRX, NRU, BGRR, EBR-II } \\
\text { Vycor Glass, JRR-2/Core 2, Core } 3\end{array}$ & 62.82 & Aluminum/Custom & 62.82 \\
\hline \multirow[t]{2}{*}{25.} & $4 / 68-6 / 68$ & $\begin{array}{l}\text { MTR, WSU, ETR, LITR, LPTR, OWR, } \\
\text { GTR, CP-5, SER, IRL, GETR, NRL, } \\
\text { Graphite, EBR-II Vycor Glass Fuel Molds }\end{array}$ & 698.37 & Aluminum/Custom & 715.62 \\
\hline & & $\mathrm{Zr}$ & 17.25 & Zirconium & \\
\hline \multirow[t]{2}{*}{26.} & $8 / 69-10 / 69$ & Zr, SNAPTRAN 2/10 - 2 Debris & 468.56 & $\begin{array}{l}\text { Co-processing } \\
\text { Zirconium }\end{array}$ & 1870.26 \\
\hline & & $\begin{array}{l}\text { MTR, ETR, GETR, Korean, SER, LITR, } \\
\text { AFNETR, JRR-2, KUR, LPTR, OWR, ATR, } \\
\text { SPERT, ZPR-III }\end{array}$ & 1401.70 & Aluminum/Custom & \\
\hline \multirow[t]{2}{*}{27.} & $2 / 71-7 / 71$ & $\mathrm{Zr}$ & 804.00 & Zirconium & 840.70 \\
\hline & & JRR-2, EBR-II Scrap, WADCO & 36.70 & Custom & \\
\hline \multirow[t]{2}{*}{28.} & $6 / 72-8 / 72$ & $\mathrm{Zr}$ & 206.0 & $\begin{array}{l}\text { Co-processing } \\
\text { Zirconium }\end{array}$ & 361.56 \\
\hline & & ETR, Custom Miscellaneous & 155.56 & Aluminum/Custom & \\
\hline 29. & $1 / 73-5 / 73$ & EBR-II & 1546.60 & $\begin{array}{l}\text { Stainless/ } \\
\text { Electrolytic }\end{array}$ & 1546.60 \\
\hline 30. & $2 / 74-5 / 74$ & $\mathrm{Zr}$ & 637.20 & $\begin{array}{l}\text { Co-processing } \\
\text { Zirconium }\end{array}$ & 1693.59 \\
\hline
\end{tabular}




\section{Table V}

Fuel Processed at ICPP

Number Date Fuel Type

U Kgs Process

Total U Kgs

\begin{tabular}{|c|c|c|c|c|c|}
\hline & & $\begin{array}{l}\text { GETR, ATR, MTR, JRR, ETR, CP-5, OWR, } \\
\text { JMTR, Juggernaut, KUR, UM, SER, LPTR, } \\
\text { EBR-II Vycor Glass, GGA Thermionic, U of } \\
\text { WY. AI Fission Disc, HTRE Scrap, Walter } \\
\text { Reed Army Hospital, Nuclear Test Gauge. } \\
\text { HTGR Ash, BMI Fission Disc }\end{array}$ & 1056.39 & Aluminum/Custom & \\
\hline 31. & $2 / 75-5 / 76$ & EBR-II & 3139.80 & $\begin{array}{l}\text { Stainless/ } \\
\text { Electrolytic }\end{array}$ & 3139.80 \\
\hline 32. & $5 / 76-9 / 76$ & $\mathrm{Zr}, \mathrm{PWR}$ & 564.6 & Zirconium & 564.6 \\
\hline 33. & $3 / 77-6 / 77$ & $\begin{array}{l}\text { Godiva, HTRE, ATR, MTR, LPT, ETR, } \\
\text { GETR }\end{array}$ & 655.22 & Aluminum/Custom & 655.22 \\
\hline \multirow[t]{2}{*}{34.} & $8 / 77-9 / 77$ & EBR-II & 390.60 & $\begin{array}{l}\text { Stainless/ } \\
\text { Electrolytic }\end{array}$ & 589.84 \\
\hline & & $\begin{array}{l}\text { MORE, SPERT, ORNL 17-1, BMI Fission } \\
\text { Disc, Kinglet, Godiva, PBF Metallurgical } \\
\text { Samples }\end{array}$ & 199.24 & Aluminum/Custom & \\
\hline \multirow[t]{2}{*}{35.} & $7 / 78-3 / 79$ & $\mathrm{Zr}$ & 342.40 & Zirconium & 377.00 \\
\hline & & Custom (Misc) & 34.60 & Custom & \\
\hline 36. & $9 / 80-3 / 81$ & $\mathrm{Zr}$ & 706.10 & $\begin{array}{l}\text { Co-processing } \\
\text { Zirconium }\end{array}$ & 1356.54 \\
\hline
\end{tabular}


Table V

Fuel Processed at ICPP

Number

Date Fuel Type

U Kgs

Process

Total U Kgs

\begin{tabular}{|c|c|c|c|c|c|}
\hline & & $\begin{array}{l}\text { Rocky Flats } \mathrm{U}_{3} \mathrm{O}_{8} \text {, GETR, OWR, STIR, } \\
\text { LPTR, UCLA-MTR, ATR, ETR }\end{array}$ & 650.44 & Aluminum/Custom & \\
\hline \multirow[t]{2}{*}{37.} & $8 / 81-11 / 81$ & EBR-II & 826.00 & $\begin{array}{l}\text { Stainless/ } \\
\text { Electrolytic }\end{array}$ & 981.00 \\
\hline & & $\begin{array}{l}\text { Los Alamos Metal Fuel Scrap, } \\
\text { Rocky Flats } \mathrm{U}_{3} \mathrm{O}_{8}\end{array}$ & 155.00 & Custom & \\
\hline 38. & $9 / 82-11 / 81$ & $\begin{array}{l}\text { ETR, BSR, ATR, OWR, ORR, HFR-Petten, } \\
\text { SAPHIR, GETR, FRG, FRJ/FRM, SFR, } \\
\text { LANL UO } \mathrm{SO}_{4},\end{array}$ & 417.17 & Aluminum/Custom & 417.17 \\
\hline \multirow[t]{2}{*}{39.} & $4 / 83-6 / 84$ & Rover & 3027.60 & Rover & 3311.00 \\
\hline & & Godiva, Rocky Flats $\mathrm{U}_{3} \mathrm{O}_{8}$, Fluorinel Startup & 219.50 & $\begin{array}{l}\text { Custom Fluorinel } \\
\text { Zirconium }\end{array}$ & \\
\hline \multirow[t]{2}{*}{40.} & $8 / 85-1 / 86$ & $\begin{array}{l}\text { ITAL, FRG, DR-3, UCLA, MURR, OWR, } \\
\text { HFBR, LPTR, TR-1, ATR, BSR, ORR, HMI, } \\
\text { TRITON, FRI-2, HFR, BR-2, ORPHEE, } \\
\text { ASTRA, SFR, R-2, JUNTA, McMaster } \\
\text { Univ., JRR-2, JMTR, JANUS, SR, UCSB } \\
\text { UO }_{2} \mathrm{SO}_{4}\end{array}$ & 722.91 & Aluminum/Custom & 725.11 \\
\hline & & Fluorinel Startup & 2.20 & Fluorinel & \\
\hline 41. & $10 / 86-10 / 87$ & Fluorinel & 809.70 & Fluorinel & 809.70 \\
\hline 42. & $12 / 87-7 / 88$ & Fluorinel & 670.70 & Fluorinel & 960.20 \\
\hline
\end{tabular}




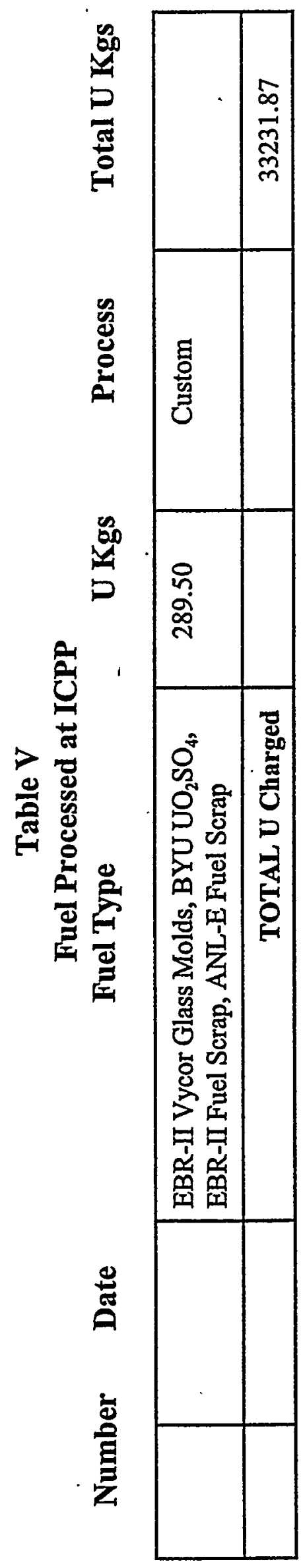




\subsection{Analytical Laboratories}

\subsubsection{Analytical Procedures}

Procedures specific to the analytical laboratories were developed to aid personnel in correctly performing various operations. These procedures were primarily to perform various physical operations in the laboratory and included such things as waste management, changing gloves on glove boxes, operation of the ventilation system, etc. The procedures were maintained in a controlled manual.

\subsubsection{Analytical Methods}

Analytical methods were specific to the particular processes being used and were developed based on standard methods, methods described in the complex literature, and methods described in the open literature. In some cases, the methods were uniquely developed for the special measurements required by the particular process. Each method was placed in a quality control program, then used only by qualified analysts trained in the details of the method. The methods were maintained in a controlled document. Most of the unique methods were used for process control purposes.

\subsubsection{Processing Issues}

During the first few years of processing, analytical samples were handled with a minimum of shielding and with the manual analytical techniques that were in use at that time. Doses were high while processing samples in that manner. The start up of the Remote Analytical Facility (RAF) relieved some of these issues, but because of the difficulties handling the samples and maintaining the equipment in the facility, many of these issues still remained until the Remote Analytical Laboratory (RAL) was placed into service in 1986.

\subsubsection{Quality Assurance}

The product solution from the extraction cycles was concentrated to approximately 350 grams per liter and stored in organ pipe banks located in CPP-602. This solution was circulated through the tube banks in an attempt to homogenize the solution. Following denitration in the fluidized bed, each $\mathrm{UO}_{3}$ product batch was mixed in a V-blender. Samples were taken from the product as it was bottled or placed in the product can. Two samples were sent to the lab for analysis. After the aliquots were taken from the two samples, the samples were blended together, sealed and stored for an archive sample representative of that product batch. Every can or bottle was analyzed for uranium isotopic composition and for total uranium content using isotope dilution mass spectrometry (DMS). The 
U-233 spikes used as the calibration spike in each sample were traceable to the National Bureau of Standards (NBS) and then later National Institute of Science and Technology (NIST) through calibration materials made available by the New Brunswick Laboratory who distributes the radioactive NBS calibration samples.

Every fifth can was analyzed for inorganic and radioactive impurities. The radionuclides included transuranic isotopes, beta emitters, and gamma emitters. The transuranics were typically analyzed using an alpha pulseheight analysis, and the beta emitters were analyzed using a gross beta count. Gamma emitters were analyzed using gamma ray spectroscopy. The labs never specifically analyzed for technetium- 99 contamination in the product.

The quality control program at ICPP was based on the routine analysis of matrix matched, blind, control samples. From this data, an estimate of the uncertainty in a measurement could be made. The assumption was that each analyst in the lab would perform like every other analyst. As a result, a single uncertainty estimate was provided with each analytical result based on the statistical data of the whole population in the laboratory. Control samples early in the program were required to be analyzed once per month. After computers came into use, control samples were analyzed on a daily basis for each method used by each analyst. This requirement was enforced through the computer, which would not accept any data from an analyst who did not meet both the precision and bias criteria for that particular analyte. This type of program was an effective daily requalification of the analyst on the methods. The programs in the computer could maintain and update the statistical data, use the statistical data to test the result to determine whether the result was within preestablished specifications, and provides a precision estimate in the form of a single standard deviation value attached to each analytical result for which the statistical data existed.

The control samples and the calibration standards were based on analytical standards available from the New Brunswick Laboratory, who distributed the radioactive standards for the NBS and later the NIST and from NBS for the non-radioactive standards. In some cases, standards were qualified by a round robin of other DOE laboratories. This was particularly true of the isotope dilution mass spectrometry (IDMS) standards used for the accountability measurements of uranium mass and the uranium isotopic distribution. 
Sampling was prescribed by specific sampling procedures to ensure that representative samples were obtained. Various techniques were used to determine that a set of samples were from the same well-mixed, homogeneous population that accurately represented the contents of a tank, product bottle, or can of product.

Characterization of the product samples was based on the receiving site's receipt criteria for the product that was in effect at the time. The primary criteria of interest seemed to be the alpha and gamma specifications. The alpha specification limited the amount of higher actinides present in the product while the gamma specification was a measure of the amount of radiation exposure expected by the workers who had to handle the product. Typically, the beta specification was of less interest because the product was handled in equipment or containers that provided shielding for the beta activity.

In addition to the radioactive component specifications there were also specifications on the amount of inorganic impurities that could be present in the product. Until the top water scrub in the third extraction cycle was installed, the ICPP product was always pushing the limit for aluminum. After the top scrub was installed, there were no problems meeting those specifications.

4.2 Neptunium, Plutonium, and Technetium in ICPP Uranium Product as Estimated by ORIGEN2 Calculations.

Because there is little analytical data on final product as a result of the records retention policy, the project resorted to estimating the quantity of plutonium, neptunium, and technetium-99 from radionuclide inventories based on ORIGEN2 code calculations. These calculations provided data on the radionuclide inventory in the dissolver product. Because the interest is on the contaminants in the final product after the fission products have been removed by the solvent extraction train, experimentally-determined decontamination factors were used to convert the calculated dissolver product radionuclide inventory into a final product inventory.

The ORIGEN2 code (Croff, A.G., 1980) is a computer program that is widely used to estimate the fission product inventory of the fuel in a reactor at any time during its lifetime. It is reactor specific and takes into account the neutron spectrum and the cross sections of the various nuclides. It also includes a half-life table to take into account the decay and ingrowth of the various radionuclides. The ORIGEN2 code also provides an estimation of the actinides produced through activation of a fraction of the uranium present. 
To estimate the fission product inventory of fuel that is to be processed, a number of assumptions must be made. The first assumptions were for the specific reactors that the fuels were irradiated in. The reactors chosen were reactors that mimicked the fuels that were predominantly processed at ICPP. For the aluminum fuels, an MTR reactor fuel that achieved maximum burnup was chosen. The initial enrichment was $93.15 \%$ U-235, and the final enrichment was assumed to be $78.21 \%$ U-235. The fission product inventory was aged for 2.8 years, and the calculation assumed one cycle in the reactor.

The second fuel chosen was a generic PWR-type zirconium-clad fuel element with an initial enrichment of $97 \%$ U-235 and final enrichment of $78.48 \%$. The neutron spectrum and the cross sections were typical of a fuel irradiated in the PWR reactor. The radionuclide inventory was assumed to have aged for 3.0 years which was assumed to be the age of the fuel at the time of processing.

The final fuel chosen was a stainless steel fuel that was irradiated in the EBR-II reactor. The EBR-II, MARK IA fuel was assumed to have been burned up in a fast reactor flux with the appropriate cross sections. The initial enrichment was assumed to be $52.9 \%$ enriched, and the final enrichment was $51.9 \%$. The fission product inventory was aged 3.0 years, which was assumed to be the age of the fuel at the time of processing.

The code was modified to provide the final output in grams of radionuclide per 100 grams of total uranium, (see Table VD) or as curies of radionuclide per gram of total uranium, as shown in Table VII. 


\section{TABLE VI}

ORIGEN2 Results in Terms of Grams/100grams of Uranium

\section{Mass of Individual Radionuclides in Dissolver Product Normalized to $\mathrm{g} / 100 \mathrm{~g}$ Total Uranium.}

\begin{tabular}{|c|c|c|c|c|c|}
\hline Nuclide & \multicolumn{2}{|c|}{ Half-Life } & $\mathbf{A l}$ & $\mathrm{Zr}$ & SS \\
\hline$U-232$ & $7.200 \mathrm{E}+01$ & $y x$ & $3.1 E-07$ & $1.3 \mathrm{E}-06$ & $2.9 \mathrm{E}-08$ \\
\hline$U-233$ & $1.592 \mathrm{E}+05$ & $y x$ & $8.7 E-06$ & $2.7 E-06$ & $2.4 E-06$ \\
\hline $0-234$ & $2.445 E+05$ & yr & $1.3 \mathrm{E}+00$ & 1. $.0 E-02$ & $5.3 E-01$ \\
\hline $0-235$ & $7.038 \mathrm{E}+08$ & yr & $7.8 E+01$ & $7.8 E+01$ & $5.2 E+01$ \\
\hline$U-236$ & $2.342 \mathrm{E}+07$ & yr & $1.3 E+01$ & $2.0 E+01$ & $3.4 E-01$ \\
\hline $0-238$ & $4.470 \mathrm{E}+09$ & yr & $7.9 E+00$ & $1.7 \varepsilon+00$ & $4.7 E+01$ \\
\hline Np-237 & $2.240 \mathrm{E}+06$ & $y x$ & $7.8 \mathrm{E}-01$ & 1. $3 E+00$ & $2.3 E-03$ \\
\hline$N p-239$ & $2.355 \mathrm{E}+00$ & $\mathrm{~d}$ & $5.6 E-10$ & $1.9 E-11$ & $2.9 E-19$ \\
\hline $\mathrm{Pu}-238$ & $8.775 E+01$ & yr & $8.1 E-02$ & $2.1 E-0 I$ & $1.3 E-05$ \\
\hline Pu-239 & $2.413 \mathrm{E}+04$ & $y x$ & $3.2 \mathrm{E}-01$ & $3.1 E-02$ & $1.4 \mathrm{E}-01$ \\
\hline Pu-240 & $6.569 \mathrm{E}+03$ & $y x$ & $5.3 E-02$ & $6.4 E-03$ & $2.9 E-04$ \\
\hline $\mathrm{Pu}-241$ & $1.440 \mathrm{E}+01$ & yr & $4.4 E-02$ & $1.4 E-03$ & $3.8 E-07$ \\
\hline Pu -242 & $3.758 \mathrm{E}+05$ & yr & $6.9 E-03$ & $2.3 \mathrm{E}-04$ & $4.4 E-10$ \\
\hline$A m-241$ & $4.322 E+02$ & yr & $6.5 \mathrm{E}-03$ & $2.8 \mathrm{E}-04$ & $6.4 E-08$ \\
\hline$A m-242 m$ & $1.520 \mathrm{E}+02$ & $\mathrm{yr}$ & $2.2 \mathrm{E}-06$ & $1.9 E-06$ & $2.9 E-12$ \\
\hline$A m-243$ & $7.380 E+03$ & $y x$ & $6.5 E-04$ & $2.2 E-05$ & $3.4 E-13$ \\
\hline Se-79 & $6.500 \mathrm{E}+04$ & yr & $1.0 \mathrm{E}-02$ & $1.7 \varepsilon-02$ & $2.2 E-04$ \\
\hline $5 x-90$ & $2.912 \mathrm{E}+01$ & yr & $1.2 E+00$ & $1.8 \mathrm{E}+00$ & $1.8 E-02$ \\
\hline$Y-90$ & $6.410 \mathrm{E} \div 01$ & $\mathrm{~h}$ & $3.0 \mathrm{E}-04$ & $4.6 E-04$ & $4.5 E-06$ \\
\hline $2 r-93$ & $1.530 \mathrm{E}+06$ & yr & $1.5 \mathrm{E}+00$ & $2.4 E+00$ & $2.4 E-02$ \\
\hline$T C-98$ & $4.200 \mathrm{E}+06$ & $y x$ & $4.5 E-06$ & $8.8 E-06$ & $3.9 E-08$ \\
\hline TC-99 & $2.130 \mathrm{E}+05$ & $Y I$ & $1.4 \mathrm{E}+00$ & $2.2 \mathrm{E}+00$ & 2. $3 E-02$ \\
\hline Pd-107 & $6.500 \mathrm{E}+06$ & yr & $5.5 E-02$ & $8.2 \mathrm{E}-02$ & $1.9 E-03$ \\
\hline$I-129$ & $1.570 \mathrm{E}+07$ & yr & $2.3 \mathrm{E}-01$ & $3.6 \mathrm{E}-01$ & $5.9 \mathrm{E}-03$ \\
\hline $\mathrm{Cs}-134$ & $2.062 \mathrm{E}+00$ & yr & $5.6 \mathrm{E}-02$ & $7.9 \mathrm{E}-02$ & $2.5 E-05$ \\
\hline Cs-135 & $2.300 \mathrm{E}+06$ & yr & 2. $2 \mathrm{E}-01$ & $1.8 E+00$ & $3.4 E-02$ \\
\hline Cs -137 & $3.000 \mathrm{E}+01$ & yr & $2.0 \mathrm{E}+00$ & $3.0 E+00$ & 3.1E-02 \\
\hline$B a-137 m$ & $2.552 \mathrm{E}+00$ & $\mathbf{m}$ & $3.0 E-07$ & $4.6 \mathrm{E}-07$ & $4.7 E-09$ \\
\hline $\mathrm{Ce}-142$ & $1.050 \mathrm{E}+11$ & $y r$ & $2.1 \mathrm{E}+00$ & $3.4 \mathrm{E}+00$ & $3.2 E-02$ \\
\hline $\mathrm{Nd}-144$ & $2.100 \mathrm{E}+15$ & yr & $2.1 E+00$ & $3.8 E+00$ & $2.9 E-02$ \\
\hline $\mathrm{Pm}-147$ & $2.623 \mathrm{E}+00$ & $y=$ & $2.6 \mathrm{E}-01$ & $1.9 \mathrm{E}-01$ & $5.6 E-03$ \\
\hline $5 m-147$ & $1.070 \mathrm{E}+11$ & $y=$ & $3.1 \mathrm{E}-01$ & $5.9 \mathrm{E}-01$ & $8.2 E-03$ \\
\hline $5 m-148$ & $8.000 \mathrm{E}+15$ & $y=$ & $1.1 E-01$ & $4.5 E-01$ & 1. $4 \mathrm{E}-04$ \\
\hline $5 m-149$ & $1.000 E+15$ & YI & $2.5 E-02$ & $7.2 \mathrm{E}-03$ & $6.6 E-03$ \\
\hline
\end{tabular}


Table VII

ORIGEN Result in Terms of $\mathrm{Ci} / \mathrm{gU}$

Activity of Individual Radionuclides in Dissolver Product Normalized to Ci / g Total Uranium.

\begin{tabular}{|c|c|c|c|c|c|}
\hline Nuclide & \multicolumn{2}{|c|}{ Half-Life } & Al & $\mathbf{Z r}$ & SS \\
\hline$u-232$ & $7.200 \mathrm{E}+01$ & yx & $6.7 \mathrm{E}-08$ & $2.7 E-07$ & $6.2 \mathrm{E}-\mathrm{C}$ \\
\hline U-233 & +05 & yr & $8.4 E-10$ & 2. $6 \mathrm{E}-10$ & \\
\hline $0-234$ & $45 E+05$ & yr & $8.1 E-05$ & $6.6 \varepsilon-07$ & 3. $3 E-05$ \\
\hline $0-235$ & $38 E+08$ & $y r$ & $1.7 \mathrm{E}-06$ & $1.7 \mathrm{E}-06$ & \\
\hline $0-236$ & $342 E+07$ & yr & $8.1 E-06$ & $1.3 \mathrm{E}-05$ & $2.2 \mathrm{E}-07$ \\
\hline $0-238$ & $470 E+09$ & yr & $2.7 E-08$ & $.6 \mathrm{E}-09$ & L. $6 \mathrm{E}-07$ \\
\hline $\mathrm{Np}-237$ & $140 \mathrm{OE}+06$ & $y x$ & $5.5 E-06$ & $1 E-06$ & 1.7 \\
\hline$N p-239$ & $355 E \div 00$ & d & $1.3 \mathrm{E}-06$ & $4.3 E-08$ & $6.8 \mathrm{E}-1$ \\
\hline Pu-238 & $775 E+01$ & yr & $1.4 E-02$ & $3.6 E$ & 2.2 \\
\hline $\mathrm{Pu}-239$ & $413 E+04$ & yr & $2.0 \mathrm{E}-04$ & $1.9 \mathrm{E}-05$ & 8.9 \\
\hline $\mathrm{Pu}-240$ & $6.569 E+03$ & yr & $1.2 \mathrm{E}-04$ & $1.5 \mathrm{E}$ & $6.6 \mathrm{E}-0$ \\
\hline Pu-241. & 440 & yr & $4.5 \mathrm{E}-02$ & $1.5 \mathrm{E}$ & 3.5 \\
\hline Pu-242 & $3.758 \mathrm{E}+05$ & yr & $2.6 \mathrm{E}-07$ & $8.8 E-09$ & $1.7 \mathrm{E}-1$ \\
\hline $\mathrm{Am}-24 \mathrm{I}$ & $4.322 E+02$ & yr & $2.2 E-04$ & $9.6 E$ & $2.2 \mathrm{E}-0$ \\
\hline$A m-242 m$ & $1.520 E+02$ & $\mathrm{yr}$ & $2.1 E-07$ & $1.8 \mathrm{E}$ & 2.91 \\
\hline$A m-243$ & $7.380 E+03$ & yr & $1.3 E-06$ & $4: 3$ & 6.8 \\
\hline $\mathrm{Se}-79$ & 04 & $y r$ & $7.3 \mathrm{E}-06$ & .05 & $1.5 \mathrm{E}-07$ \\
\hline$S I-90$ & $2.912 \mathrm{E}+01$ & yr & $1.6 \mathrm{E}+00$ & $2.5 \mathrm{~B}$ & $2.5 E-0$ \\
\hline & 6.41 & $\mathrm{~h}$ & $1.6 \mathrm{E}+00$ & 2.5 & 2 \\
\hline $2 x-93$ & 1.53 & yx & $3.7 E-05$ & 05 & 5. \\
\hline TC-98 & +06 & yr & $3.9 \mathrm{E}-11$ & 7. & 3.4 \\
\hline Tc-9g & 1 & $y r$ & $2.4 E-04$ & 3.8 & 3.9 \\
\hline$P d-107$ & $6.500 \mathrm{E}+06$ & $y x$ & $2.8 \mathrm{E}-07$ & $4.2 \mathrm{E}$ & 1. $.0 E-0$ \\
\hline & 1.570 & yr & $4.08-07$ & -07 & $1.0 \mathrm{E}-0$ \\
\hline $\mathrm{Cs}-134$ & $2.062 E+00$ & yr & $7.2 E-01$ & $1.0 E+00$ & $3.2 E-0$ \\
\hline Cs. & $2.300 E+06$ & yr & $2.5 E-06$ & 2. & $4.0 \mathrm{E}-07$ \\
\hline Cs -137 & $3.000 \mathrm{E}+01$ & $\mathrm{yr}$ & $1.7 E+00$ & 2.6 & $2.7 E-0$ \\
\hline$B a-137 m$ & $2.552 E+00$ & m & $1.6 E+00$ & 2.5 & \\
\hline & $1.050 \mathrm{E}+11$ & yr & $5.0 \mathrm{E}-10$ & 8.1 & $7.6 \mathrm{E}-1$ \\
\hline & $00 E+15$ & yx & $2.5 E-14$ & $4.5 \mathrm{E}-14$ & 3.4 \\
\hline & $2.623 E+00$ & $y x$ & $2.4 \mathrm{E}+00$ & $1.8 \mathrm{E}$ & $5.2 E$ \\
\hline & $1.070 E+11$ & yx & $7.08-11$ & $1.3 E-10$ & $1.9 E$ \\
\hline & $0 E+15$ & yr & $3.3 E-16$ & $1.4 \mathrm{E}-15$ & \\
\hline & & & & -17 & \\
\hline
\end{tabular}


The second part of developing the means to estimate fission product and actinide content in the final product at ICPP was to convert ORIGEN2 code calculated values for those radionuclides that would be present in the dissolver product into concentrations that are representative of the final product. To do this, experimentally-determined values for the efficiency of the decontamination of the dissolver product as it passes through the three extraction cycles were used to calculate the expected concentrations of the contaminants of interest.

ORIGEN2 code calculations were completed for fission products and transuranics that would be present in dissolver product from the three fuel processes (aluminum, zirconium, and electrolytic) used at ICPP. By using this classification, the differences that arise because of the processing chemistry and that would affect the decontamination factor could be taken into account. This approach also recognized differences in enrichment and burnup between aluminum and stainless steel. A fourth process at ICPP processed the low-burnup ROVER fuel, which was contact handled before it was charged to the primary burner. Because the aqueous process for this fuel was essentially identical to the zirconium process, it is conservatively assumed to be bounded by the zirconium process. The dissolver product actinide and fission product estimates from the ORIGEN2 calculations were compared with analytical data on dissolver product samples.

The plutonium, neptunium, and technetium data were converted from calculated dissolver product data to final product information by applying decontamination factors (DFs). The DFs were developed for each process and defined as the ratio of the actinide or fission product in the dissolver product to the actinide or fission product in the final product. The decontamination factors could then be used to estimate the final product contaminant concentration values by dividing the dissolver product concentrations of plutonium, uranium, and technetium by the respective decontamination factor.

Final product values for plutonium, neptunium, and technetium were not recorded explicitly during ICPP operations from 1953 through 1992. For Pu, the receiver (generally Y-12) had provided guidance on minimal acceptance limits for product uranium/plutonium alpha ratios. Estimates on the uranium/plutonium product mass ratios can be calculated when the alpha ratio is available. Neptunium limits were not provided by product receivers, and neptunium data is very limited. Technetium was never determined for ICPP uranium product and must be estimated from process decontamination factors for total beta.

The measured alpha ratios (total uranium product alpha/plutonium alpha) for ICPP uranium product was routinely reported (Henry, 1971; Henry, 1973; Wheeler, 1966; Bjorklund, 1974; Bendixsen, 1972; Offutt, 1968; Bendixsen, 
1969), and the range of values for a variety of spent fuel types processed could be assessed from a number of published campaign reports. The observed ranges for aluminum, zirconium, and stainless steel are 600-5000, 2000-400,000, and 1000160,000 , respectively. The resulting uranium/plutonium mass ratios in the ICPP product are shown in Table VIII.

The confidence and validity of the product mass ratios can be checked through using measured and recorded decontamination factors for plutonium. The uranium/plutonium mass ratio in the product can be estimated by multiplying the process feed concentrations (fuel dissolver product) with the overall three-cycle decontamination factor. This comparison of two methods for estimating the uranium/plutonium product mass ratio is summarized in Table VIII. It is observed that the U/Pu mass ratio as estimated by the decon factor is consistently lower than that estimated using the alpha ratios. However, as one observes, the two order magnitude variability in alpha ratio and decontamination factor makes a one order of magnitude variability in the comparison less important.

Since the alpha ratio is a more direct product measurement, its uranium/plutonium mass ratio may be considered the more reliable. Table IX lists the contaminant mass ratios which are considered to be a practical maximum for the ICPP product. These values were developed from the ORIGEN2 code calculated values.

Very few neptunium analyses were made in the three-cycle extraction process streams, and no analyses were made for neptunium ICPP uranium product. Some limited data on neptunium decontamination factors are available in the run reports referenced above. From these, a nominal and conservative decontamination factor (product/feed) of $3.2 \times 10^{4}$ has been estimated.

Technetium-99 analyses were never analyzed in ICPP product streams. However, overall beta decontamination factors were measured and documented. The campaign reports consistently noted that ruthenium was the dominant beta emitter with the lowest decontamination factor. Thus, the overall beta decontamination factor for technetium values used in Table IX is confidently believed to be conservative. 


\section{Table VIII}

COMPARISON OF Pu/U MASS RATIOS

FROM MEASURED DECONTAMINATION FACTORS AND ALPHA RATIOS

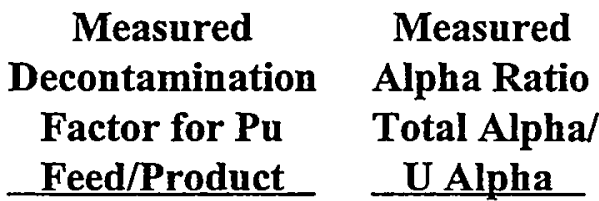

Aluminum Clad Fuels

High

Median

Low

High

Median

Low

High

Median

Low
$5.0 \mathrm{E}+03$

$2.4 \mathrm{E}+05$

$1.5 \mathrm{E}+03$

$5.0 \mathrm{E}+03$

$6.0 \mathrm{E}+02$

$1.0 \mathrm{E}+03$

PWR Zirconium Fuels

4.0E+05

$8.0 \mathrm{E}+03$

$5.2 \mathrm{E}+04$

$2.0 \mathrm{E}+03$

$7.3 \mathrm{E}+03$

$4.0 \mathrm{E}+02$

\section{Stainless Steel Fuels}

$1.6 \mathrm{E}+05$

$1.0 \mathrm{E}+05$

$4.0 \mathrm{E}+04$

$1.0 \mathrm{E}+04$

$1.0 \mathrm{E}+03$

$1.0 \mathrm{E}+03$
Calculated Product

Pu/U Mass Ratio, gPu/gU

Calculated from Calculated from

ORIGEN2 Code Data, the Measured

Decontamination Factors Alpha Ratio

Aluminum Clad Fuels

Low

$1.0 \mathrm{E}-06$

3.0E-09

3-4E-06

$1.4 \mathrm{E}-07$

8.4E-08

7.2E-07

PWR Zirconium Fuels

Low 1.0E-06

2.0E-09

Median

3.4E-06

$1.4 \mathrm{E}-08$

High

8.4E-06

2.6E-07

Stainless Steel Fuels

Low 8.8E-09

5.2E-07

Median

3.5E-08

5.2E-06

High

1.4E-06

5.2E-06 
Table IX

Contaminants in ICPP Product. Based on ORIGEN2 Code Calculations and DFs from ICPP Process Data

\begin{tabular}{|c|c|c|c|c|}
\hline Isotope & $\begin{array}{l}\text { Dissolver Product } \\
\text { Concentration } \\
\text { g/gU }\end{array}$ & $\begin{array}{c}\text { Total Element in } \\
\text { Dissolver Product } \\
\text { g/gU } \\
\text { Alumin }\end{array}$ & $\begin{array}{c}\text { Average } \\
\text { DF } \\
\text { Product/Feed } \\
\text { Process }\end{array}$ & $\begin{array}{c}\text { Product } \\
\text { Contaminant } \\
\text { Concentration } \\
\text { g/gU }\end{array}$ \\
\hline $\begin{array}{l}\mathrm{Pu}-238 \\
\mathrm{Pu}-239 \\
\mathrm{Pu}-240 \\
\mathrm{Pu}-241 \\
\mathrm{Pu}-242\end{array}$ & $\begin{array}{l}8.1 \times 10^{-4} \mathrm{~g} / \mathrm{gU} \\
3.2 \times 10^{-3} \\
5.3 \times 10^{-4} \\
4.4 \times 10^{-4} \\
6.9 \times 10^{-5}\end{array}$ & $5.0 \times 10^{-3}$ & $6.7 \times 10^{-4}$ & $3 \times 10^{-6}$ \\
\hline Np-237 & $7.8 \times 10^{-3}$ & $7.8 \times 10^{-3}$ & $3.4 \times 10^{-4}$ & $2.5 \times 10^{-6}$ \\
\hline c-99 & $1.4 \times 10^{-2}$ & $1.4 \times 10^{-2}$ & $8 \times 10^{-8}$ & $1 \times 10^{-9}$ \\
\hline
\end{tabular}

Stainless Steel Process

Pu-238

Pu-239

$\mathrm{Pu}-240$

$\mathrm{Pu}-241$

$\mathrm{Pu}-242$

$\mathrm{Np}-237$

Tc-99

$1.3 \times 10^{-7} \mathrm{~g} / \mathrm{gU}$

$1.4 \times 10^{-3}$

$2.9 \times 10^{-6}$

$1.4 \times 10^{-3}$

$2.5 \times 10^{-5}$

$3.5 \times 10^{-8}$

$3.8 \times 10^{-9}$

$6.9 \times 10^{-12}$

$2.3 \times 10^{-5}$

$2.3 \times 10^{-5}$

$3.2 \times 10^{-4}$

$7.4 \times 10^{-9}$

$2.3 \times 10^{-4}$

$2.3 \times 10^{-4}$

$8 \times 10^{-8}$

$2 \times 10^{-11}$

\section{Zirconium Process}

Pu-238

Pu-239

Pu-240

$\mathrm{Pu}-241$

$\mathrm{Pu}-424$

Np-237

$2.1 \times 10^{-3} \mathrm{~g} / \mathrm{gU}$

$3.1 \times 10^{-4}$

$6.9 \times 10^{-5}$

$1.4 \times 10^{-5}$

$2.5 \times 10^{-3}$

$1.2 \times 10^{-4}$

$3 \times 10^{-7}$

Tc-99

$2.3 \times 10^{-6}$

$1.3 \times 10^{-2}$

$1.3 \times 10^{-2}$

$3.2 \times 10^{-4}$

$4 \times 10^{-6}$

$2.2 \times 10^{-2}$

$2.2 \times 10^{-2}$

$8 \times 10^{-8}$

$1.7 \times 10^{-9}$ 
Table IX shows the ORIGEN2 calculated dissolver product data for plutonium, neptunium, and technetium for each of the three main processes. It also shows the decontamination factors and finally the contaminant values for the final product. The total amount of the isotopes of interest can be obtained by multiplying the number of grams shipped by the number of grams of isotope per gram $U$.

\subsection{Analytical Results for Plutonium}

\subsubsection{Plutonium Specification}

The plutonium specification for material to be shipped from ICPP was that the total alpha was not to exceed $5000 \mathrm{dpm} / \mathrm{gU}$. Experimentally, as reported in the Egli report (Egli 1985), the alpha ratio for total transuranics did not exceed $61 \%$ and ranged from $31 \%$ to $61 \%$ of Y-12 informal specification. Since 1977 , the alpha ratio has been $31 \%$ of $Y-12$ specification.

4.3.2 Impurity Concentrations for Plutonium in Materials Shipped Using the data in Table IX, the total plutonium contamination in the final product is $3 \times 10^{-6} \mathrm{~g} \mathrm{Pu} / \mathrm{gU}$ for aluminum fuels, $3.5 \times 10^{-8} \mathrm{gPu} / \mathrm{gU}$ for stainless steel fuels, and $3 \times 10^{-7} \mathrm{Pu} / \mathrm{gU}$ for zirconium fuels. The decontamination factors used to determine these concentrations are median values from run reports. Some of the plutonium isotope amounts relative to total uranium in the final product are $5.4 \times 10^{-7} \mathrm{~g} / \mathrm{gU}$ in aluminum product, $3.3 \times 10^{-12} \mathrm{~g} / \mathrm{gU}$ in stainless steel product, and $2.5 \times 10^{-7} \mathrm{~g} / \mathrm{gU}$ in zirconium product. For $\mathrm{Pu}-239$ the concentrations in final product are 2.1 $\mathrm{x} 10^{-6} \mathrm{~g} / \mathrm{gU}$ in aluminum product, $3.5 \times 10^{-8} \mathrm{~g} / \mathrm{gU}$ in stainless steel product, and $3.7 \times 10^{-8} \mathrm{~g} / \mathrm{gU}$ in zirconium product.

Using the specification of $5000 \mathrm{dpm} / \mathrm{gramU}$ a "most probable" result for the alpha contamination can be calculated. These results depend on the isotopic distribution for plutonium from the ORIGEN2 calculation to obtain the most probable value for total plutonium. This calculation produced the result for plutonium which is shown in Table IX. These results are distributed to recognize that the alpha specification is composed of contributions from plutonium and neptunium as well as other higher actinides. The plutonium and neptunium were distributed as a fraction of their mass. Since the alpha specification was at a maximum of $61 \%$ of the alpha specification between 1953 and 1976. From 1977 on, the product shipments were $31 \%$ of the alpha specification. Thus, there are two entries in the table that distribute the two alpha emitting elements as pre-1976 and post 1976. Because ROVER was a low-burnup fuel, the assumption was made that no significant quantity of plutonium, neptunium and technetium-99 built up in product from this fuel.

Table $\mathrm{X}$ shows the total quantities of plutonium, neptunium and technetium-99. 
Table XII shows the total quantities of plutonium, neptunium and technetium-99 shipped to the receiving sites.

4.4 Analytical Results for Neptunium in Uranium Materials Shipped

4.4.1 Neptunium Specifications Uranium Materials Shipped

There was no specific neptunium specification other than the general transuranic alpha specification noted above.

4.4.2 Impunity Concentration for Neptunium in Recycled Uranium Shipped The neptunium plus the plutonium could not exceed $5000 \mathrm{dpm} / \mathrm{gU}$. Since the data in the Egli report indicated that the sum of the neptunium plus the plutonium was consistently below the alpha specification through 1985 and since no modifications were made to the ICPP facility that would adversely affect the decontamination of the alpha emitting transuranic radionuclides, it is expected that this specification which was met for the sum of the amount of plutonium and neptunium, would also be met for neptunium by itself. The neptunium results are also shown in Tables XII, XIII and XIV.

4.5 Analytical Results for Technetium in Uranium Materials Shipped

4.5.1 Technetium Specification in Recycled Uranium

There was no technetium-99 specification in existence during the period that ICPP operated.

\subsubsection{Impurity Concentration for Technetium in Uranium Materials Shipped} Since there was no technetium-99 impurity specification for the recycled uranium that ICPP recovered and shipped, there was no attempt made to measure it in the final product. However, it is known that the beta emitter that caused the greatest problem in recycled uranium was ruthenium. It is not expected that the technetium was a significant contaminant in the ICPP uranium product. The technetium results shown in Table XII, XIII, and XIV were calculated from the ORIGEN2 data and the Dfs for technetium-99.

4.6 Analytical Results for Material Received The ICPP material received was spent fuel. As such, it is out of the scope of this project.

4.7 Discussion of Other Constituents Because ICPP.processed highly-enriched spent fuel, there was a significant amount of isotopes of uranium other than U-238 and U-235 that were produced by the reactor. The U-236 concentration in the final product averaged, $7.6 \%$ but 
peaked as high as $19.1 \%$. The U-234 concentration averaged approximately $1 \%$ but peaked as high as $1.5 \%$.

The uranium-236 content of the fuels varied due to the type of fuel processed. The fuel's uranium-236 content was a function of the burnup and the reactor's neutron spectrum. To determine the average uranium-236 content of the various fuels, analytical data based on the isotopic analyses of monthly composite samples of dissolver product were used. These samples were taken during the operating periods from October, 1980 through November of 1982. The measured uranium-236 were averaged for the specific fuel type and are presented in Table X.

Table X

Uranium-236 Content of ICPP Fuels

Fuel Type

$$
\begin{gathered}
\text { Fuel Quan } \\
\text { Kgs }
\end{gathered}
$$

Average U-236\%

Content

Range

16,147

8.42

Percent

Total U-236

$\mathrm{Kgs}$

Aluminum

Zirconium

5,468

15.81

$6.43-11.69$

1360

Stainless Steel

5,885

$1.08-1.65$

77

ROVER

$$
\underline{2,782}
$$

0.0

$13.15-19.08$

864

$30,282 \mathrm{KgsU}$

$2301 \mathrm{KgsU}-236$

The amount shipped to the various receiving sites and the fuel types they received is shown in Table XI. 
Table XI

Uranium-236 Quantities Sent to Receiving Sites

\begin{tabular}{lclc} 
Receiving Site & $\begin{array}{c}\text { Uranium Shipped } \\
\text { Kgs }\end{array}$ & \multicolumn{1}{c}{$\begin{array}{c}\text { Fuel Types Sent } \\
\text { Kgs }\end{array}$} & $\begin{array}{c}\text { Total U-236 } \\
\text { Kgs }\end{array}$ \\
\hline Y-12 & 25,773 & $\begin{array}{l}\text { Aluminum, stainless } \\
\text { steel, zirconium, } \\
\text { ROVER }\end{array}$ & 2,227 \\
Portsmouth & 4,076 & Stainless steel & 53 \\
Rocky Flats & 219 & Aluminum & 18 \\
Los Alamos & 168 & ROVER & 0 \\
PNNL & 47 & Aluminum & 4 \\
Totals & 30,283 & & 2,302
\end{tabular}

The range of values is also presented. ROVER fuel was a low burnup fuel and was assumed to have no uranium-236.

Table XII

Concentration of Contaminants in ICPP Product

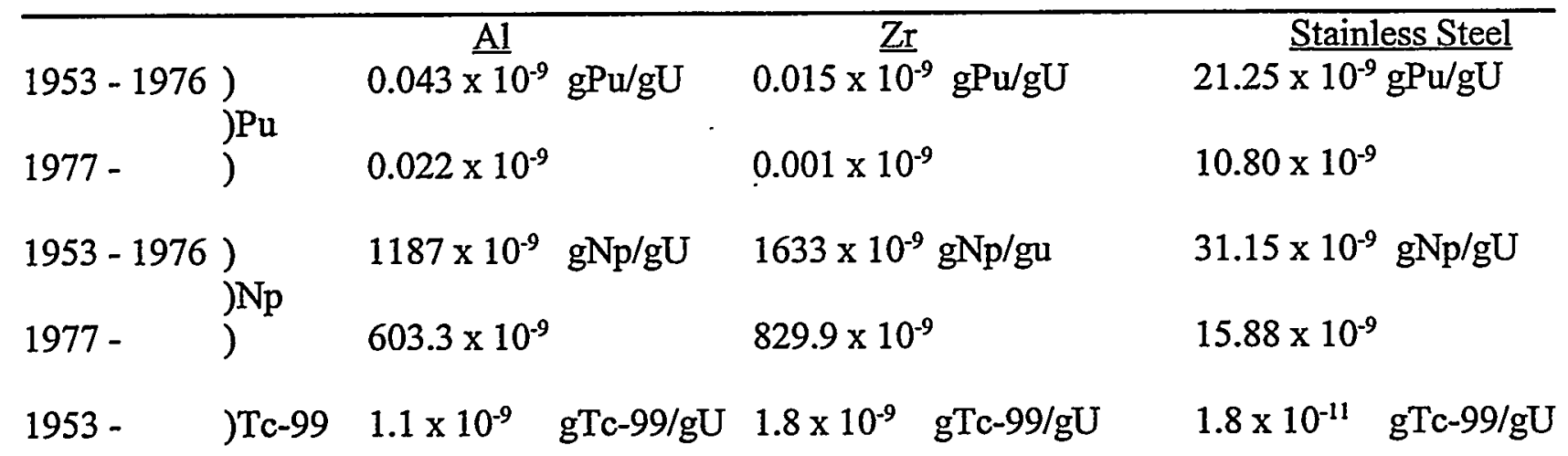


Table XIII

Contaminants in ICPP Product

\begin{tabular}{|c|c|c|c|c|}
\hline Al Fuel & Total U Kgs & Plutonium(grams) & Neptunium(grams) & Technetium-99(grams) \\
\hline $19 \overline{53-1976}$ & 13,333 & $5.7 \times 10^{-4}$ & 15.83 & 0.015 \\
\hline $1977-$ & 2,814 & $6.2 \times 10^{-5}$ & 1.70 & 0.003 \\
\hline \multicolumn{5}{|l|}{ Zr Fuel } \\
\hline $1953-1976$ & 3,082 & $4.6 \times 10^{-5}$ & 5.03 & 0.006 \\
\hline $1977-$ & 2,385 & $2.4 \times 10^{-6}$ & 1.98 & 0.004 \\
\hline \multicolumn{5}{|l|}{ Stainless Fuel } \\
\hline$\overline{1953-1976}$ & 4,508 & 0.096 & 0.140 & 0.0001 \\
\hline 1977 - & 1,377 & 0.015 & 0.022 & 0.00002 \\
\hline ROVER Fuel & 2,783 & - & - & 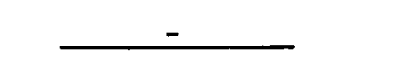 \\
\hline Total Shipped & $30,283 \mathrm{Kgs}$ & 0.112 grams $\mathrm{Pu}$ & 24.70 grams $N p$ & 0.028 grams Tc- 99 \\
\hline Inventory & 1,770 & $\underline{0.019}$ & 1.47 & $\underline{0.003}$ \\
\hline \multirow[t]{3}{*}{ Total Processed } & $32,053 \mathrm{KgsU}$ & 0.131 grams $\mathrm{Pu}$ & 26.17 grams $\mathrm{Np}$ & 0.031 grams Tc-99 \\
\hline & \multicolumn{3}{|c|}{$\begin{array}{c}\text { Table XIV } \\
\text { Material Shipped from ICPP }\end{array}$} & \\
\hline & Uranium Kgs & Plutonium grams & Neptunium grams & Technetium-99 grams \\
\hline Portsmouth & 4,076 & 0.087 & 0.127 & 0.0001 \\
\hline $\mathrm{Y}-12$ & 25,773 & 0.025 & 24.3 & 0.028 \\
\hline Rocky Flats & 219 & 0.00001 & 0.26 & 0.0002 \\
\hline PNNL & 47 & 0.00000 & 0.03 & 0.0001 \\
\hline LASL & 168 & - & - & - \\
\hline
\end{tabular}


5.1 Annual Mass Balance of Recycled Uranium

Recycled uranium was the product of the ICPP. With the exception of two small shipments, all of the recycled uranium at ICPP was the product of the uranium reprocessing operation. The two small shipments were returns of ICPP product from facilities that had received it from ICPP. One shipment was a denitrator product prepared at Y-12 from liquid ICPP product to produce the granular, highenriched material needed to start up the ICPP denitrator. The second shipment was a partial return of material shipped to PNNL for criticality experiments but was not required for their needs.

The bulk of the material shipped from ICPP, went to Y-12. Most of the rest was sent to Portsmouth. The annual shipments are shown in Table XV which includes "most probable" estimates of the contaminants in the final product.

5.2 Annual Mass Balance for Plutonium

The plutonium contaminants were based on information from the Egli report which indicated that the alpha concentration was less than the alpha specification. In the period from 1953 to 1977 the alpha content varied between 22 and $61 \%$ of Y-12s informal specification. Since 1977 the alpha content has been $31 \%$ of the specification.

By utilizing those facts and using a conservative alpha specification which says that the alpha content can not exceed $5000 \mathrm{dpm}$ transuranic alpha per gram of uranium, estimates for the alpha content can be made. The annual mass balance for shipments for plutonium is shown in Table XV.

5.3 Annual Mass Balance for Neptunium The neptunium content is also a contributor to the alpha specification. If it is assumed that it behaves in the same way that plutonium does in the extraction system, an estimate for the neptunium content can be obtained. These values are shown in Table XV.

5.4 Annual Mass Balance for Technetium-99

The technetium-99 contamination was determined by using the ORIGEN2 calculated data for dissolver product. This was converted to final product values using the beta decontamination factor which was general for all beta emitters. These values are shown in Table X. Because the predominant beta emitter was ruthenium-106, this estimate for technetium-99 is considered to be higher than actual values. 


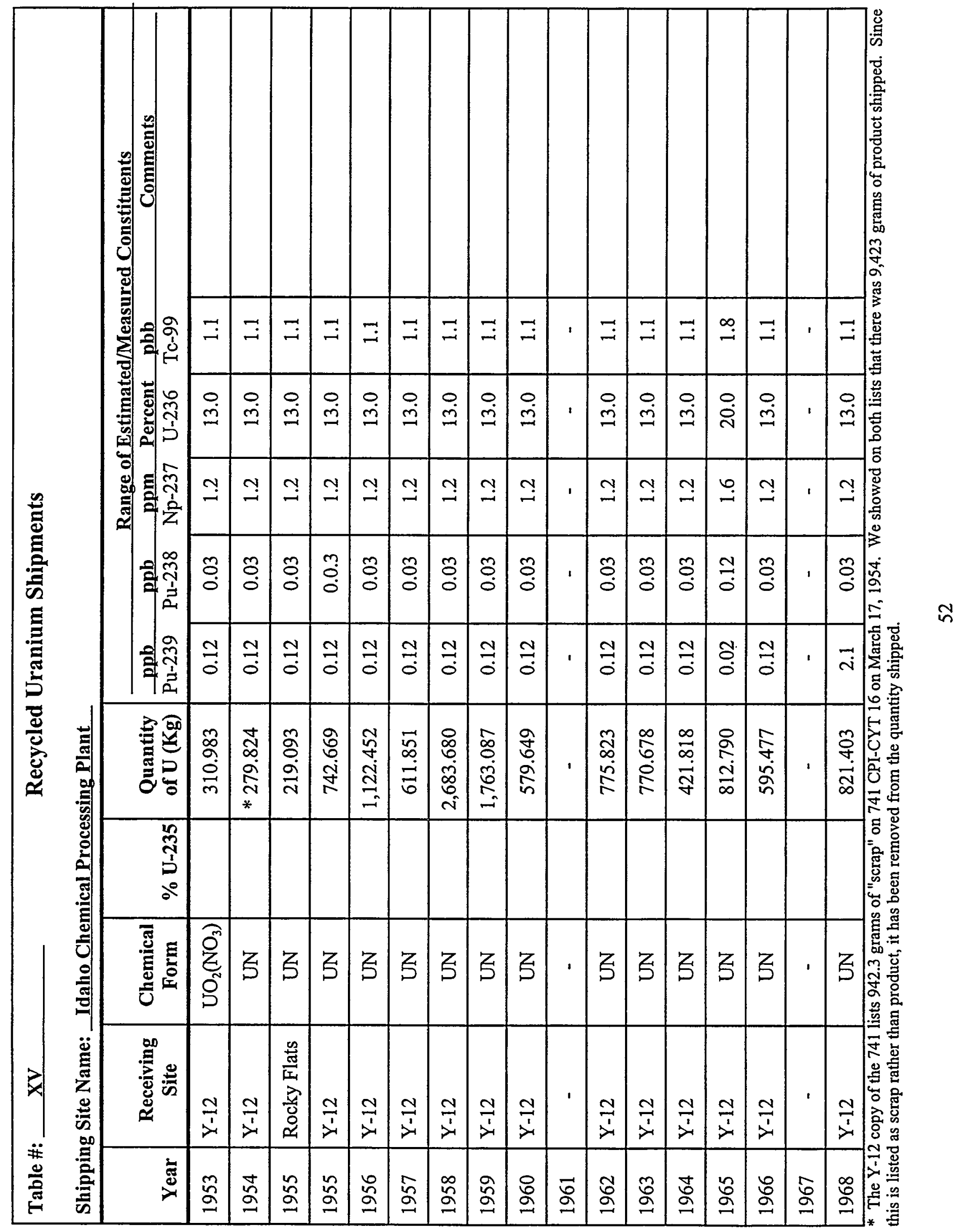




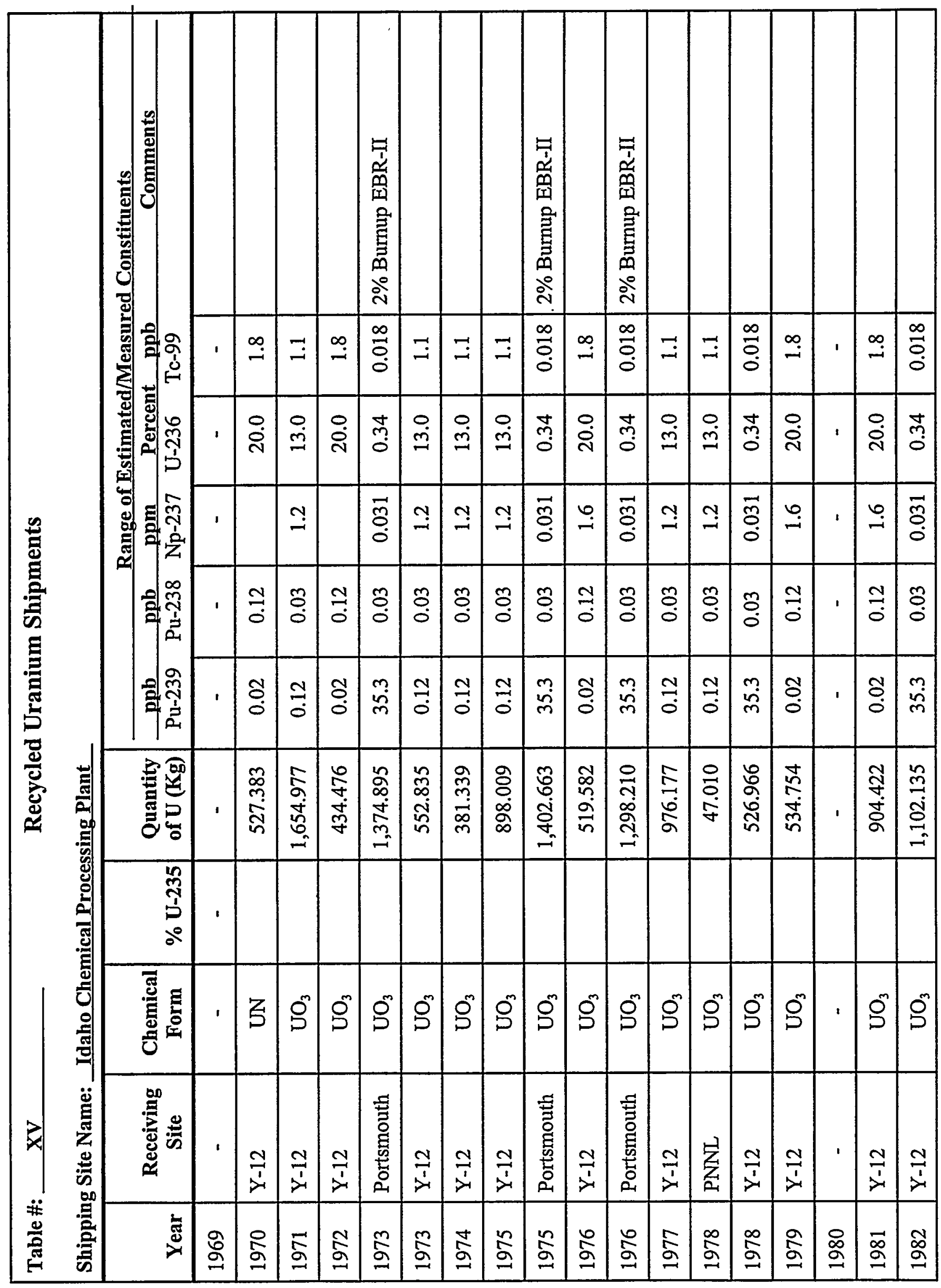




\begin{tabular}{|c|c|c|c|c|c|c|c|c|c|c|}
\hline \multicolumn{11}{|c|}{$\begin{array}{l}\text { Table \#: } \frac{\mathrm{XV}}{\text { Recycled Uranium Shipments }} \\
\text { Shipping Site Name: Idaho Chemical Processing Plant }\end{array}$} \\
\hline \multirow[b]{2}{*}{ Year } & \multirow[b]{2}{*}{$\begin{array}{c}\text { Receiving } \\
\text { Site }\end{array}$} & \multirow[b]{2}{*}{$\begin{array}{c}\text { Chemical } \\
\text { Form }\end{array}$} & \multirow[b]{2}{*}{$\%$ U-235 } & \multirow[b]{2}{*}{$\begin{array}{l}\text { Quantity } \\
\text { of } \mathbf{U}(\mathbf{K g})\end{array}$} & \multicolumn{6}{|c|}{ Range of Estimated/Measured Constituents } \\
\hline & & & & & $\begin{array}{l}\text { ppb } \\
\mathrm{Pu}-239\end{array}$ & $\frac{\text { ppb }}{\mathrm{Pu}-238}$ & $\operatorname{Npm}_{\mathrm{Np}-237}$ & $\frac{\text { ercent }}{U-236}$ & Tc-99 & Comments \\
\hline 1983 & $\mathrm{Y}-12$ & $\mathrm{UO}_{3}$ & & 517.913 & 0.12 & 0.03 & 1.2 & 13.0 & 1.1 & \\
\hline 1984 & $\mathrm{Y}-12$ & $\mathrm{UO}_{3}$ & & $* 2,868.215$ & - & - & - & - & - & Lightly Irradiated ROVER \\
\hline 1984 & LASL & UN & & * 167.606 & - & - & - & - & - & Lightly Irradiated custom \\
\hline 1985 & - & - & & - & - & - & - & - & - & \\
\hline 1986 & $Y-12$ & $\mathrm{UO}_{3}$ & & 955.115 & 0.12 & 0.03 & 1.2 & 13.0 & 1.1 & \\
\hline 1987 & - & - & & - & - & & & & & \\
\hline 1988 & - & - & & - & - & & & & & \\
\hline 1989 & - & - & & - & - & & & & & \\
\hline 1990 & - & - & & - & - & & & & & \\
\hline 1991 & - & - & & - & - & & & & & \\
\hline 1992 & - & - & & - & - & & & & & \\
\hline 1993 & - & - & & - & - & & & & & \\
\hline 1994 & $\mathrm{Y}-12$ & $\mathrm{UO}_{3}$ & & * 116.496 & - & - & - & - & - & Lightly Irradiated custom \\
\hline 1995 & - & - & & - & - & & & & & \\
\hline 1996 & - & - & & - & - & & & & & \\
\hline 1997 & - & - & & & & & & & & \\
\hline 1998 & $\mathrm{Y}-12$ & $\mathrm{UO}_{3}$ & & 0.424 & 0.02 & 0.12 & 1.6 & 20.0 & 1.8 & \\
\hline
\end{tabular}

* The material in these three shipments were lightly irradiated or unirradiated custom processing materials. Most of the lightly irradiated material was ROVER product. 
5.5 Annual Mass Balance for Other Constituents

The U-236 values shown in Table XV were values actually measured on composited samples of dissolver product during the late 1980s. These values are the maximum values reported for uranium-236 and were determined by mass spectrometry.

Uranium-236 was included because it results in significant radiation exposures in aged material due to the presence of decay product, uranium-232 and its daughters, particularly thallium-208 which is short-lived with a high-energy $(2.6 \mathrm{Mev})$ gamma emission.

5.6 Potential for Worker Exposure from Recycled Uranium

As the calculations in Section 2.4 indicated most of the effective dose equivalent exposures would be due to the uranium radionuclides (see Table III). Uranium-234, Because of its short half-life $\left(2.45 \times 10^{-5}\right.$ years $)$ compared to the half-lives $\left(10^{-7}\right.$ to $.10^{-9}$ years) of the other uranium isotopes in ICPP product, uranium-234 is often the dose limiting radionuclide. Uranium-234 is significantly concentrated by the gaseous diffusion plants and then increased slightly more in a reactor through $\mathrm{n}, 2 \mathrm{n}$ reactions with uranium-235. Throughout the history of ICPP, the risk of exposure to radionuclides in final product was based on the uranium isotopes rather than the actinide or fission product radionuclide. As can be seen in Table III, the plutonium isotopes are at least an order of magnitude lower risk than the highest risk uranium isotope. High-enriched, high-burnup fuels have high concentrations of uranium$234,-235$, and -236 which are the limiting isotopes in handling ICPP product.

The bioassay programs would pick up internal exposures to uranium. The uranium that was frequently observed was usually natural uranium from the environment and was not considered to be a problem at that level. The presence of uranium-234 or uranium-236 or of higher enrichments of uranium-235 would result in follow up to determine the extent of the dose and the source. In general, because of the monitoring for uranium isotopes, the risk of exposure to other constituents in ICPP product, was small.

5.7 Potential for Environmental Contamination from Recycled Uranium. There was no risk of environmental contamination from ICPP recycled uranium product.

\subsection{RESULTS AND CONCLUSIONS}

6.1 Explanation of Mass Flow Paths and Contaminant Levels Material shipped from the Idaho Chemical Processing Plant was sent to Y-12 and to Portsmouth for future processing. Smaller quantities were sent to Rocky Flats, Hanford and Los Alamos for criticality studies. This material was subsequently either returned to ICPP for cleanup or sent directly to $Y-12$ for processing prior to being shipped to Savannah River. Some is still believed to be in inventory at the 
receiving site. Alpha contamination of material sent to $\mathrm{Y}-12$ was below their specification. Beta contamination was four to five times their specification in shipments sent between 1953 and 1977. After 1977, the beta contamination was consistently below their specification.

6.2 Identification of Processes or Areas of Concern for Worker Exposure Exposure to the product material was to the operations personnel who packaged the product and took samples, maintenance personnel who maintained the final product equipment, health physics personnel monitoring radiation exposures, and to the analytical personnel who analyzed the product samples. Prior to 1971, the product and the samples were liquids in the form of a concentrated uranyl nitrate solution in nitric acid. After 1971, the product and the samples were essentially pure uranium trioxide powder and particles. The highest risk was due to the uranium isotopes compared to the other actinides or to technetium.

6.3 Identification of Processes or Areas of Concern for Environmental Impact Environmental impact statements have been prepared for all phases of the processes at ICPP. No areas of concern with respect to any of the processes for the handling of final product were identified.

6.4 Discussion of Data Sources and Confidence Levels

Three different sources of shipment data were used to determine the amount of product that was shipped from the ICPP. The data was taken from DOE/OR-859 (The Egli Report), a collection of monthly ICPP production reports, and a compilation of shipments by date and RIS codes made by an accountability manager. The combination of this data appears to provide an accurate assessment of the shipments, particularly in the absence of a large fraction of the 741 forms from one of the early site contractors. A subsequent check at Y-12 indicated that the shipping records that they had, matched the tables of shipments made through the years as documented by the accountability personnel at ICPP.

Original analytical data was sent to a records repository in Seattle and then subsequently destroyed. Compiled data from some of the more recent shipments is available for transuranics in the dissolver product. Additional data is given in the Egli Report (DOE/OR-859) based on information developed at Y-12 when analyses were completed on uranium product sent to $\mathrm{Y}-12$.

Analyses for technetium do not exist at ICPP. Technetium was never a concern in the product and as such was never requested. Because it was not a concern, an analytical method was not developed for the separation and analysis of technetium until 1998.

Because original records do not exist for much of the data, confidence in the data is not as high as it would be with a complete, original data set. The use of original, complete data sets would produce the highest level of confidence. But, because a 
significant amount of data has been lost or destroyed, this level of confidence is not possible. Ideally, the backup information normally associated with the shipping documents would include the analytical chemistry data, description of the material in the shipment, shipment packaging, etc. This means that other sources of data must be identified and utilized. The confirmation that the records that $\mathrm{Y}-12$ have matches the tabular shipping data gives confidence that these are equivalent to original data.

What is available are several different data sets that were produced for different reasons for different groups. The fact that this data is quite consistent provides confidence that even though the original data is lost, the data that has been preserved as a secondary source of data is consistent and therefore increases confidence in these secondary sources. A paragraph in the Egli report indicates that transuranic alpha contamination was always below the receiver's specification. In the early years, the beta contamination was four to five times the specification but from 1977 on, the beta activity was below the specification. Utilizing this information allows one to back calculate the alpha emitting materials present in the product. This allows one to estimate, with confidence, the amount of transuranics in the ICPP product.

Estimates of the range of the constituents content in the three fuel types was made by using the data that was calculated based on the alpha specification and on the values calculated from the DFS and the ORIGEN2 results. As indicated earlier the "most probable" constituent levels are based on the data presented in the Egli report. The Egli data is based on analytical results of product received at Y-12. The data from the ORIGEN2 calculations combined with the experimental DFs both have large uncertainties which are probably over estimating the contaminant concentrations.

The ranges are shown in Table XVI. For plutonium the range is very large for aluminum and zirconium fuels. For stainless steel, the range is actually quite narrow, probably due to the fact that fuel had a lower burnup, and because the plutonium isotopic distribution is essentially only the plutonium-239 isotope.

The range for neptunium is also close together again probably because there is only a single isotope produced.

The technetium-99 data is only based on the ORIGEN2 calculations and the total beta DF. Because it is known that the isotope that affected the beta ratio data was primarily ruthenium-106 rather than technetium-99, the entire range probably significantly over estimates the technetium-99 concentration. 
Table XVI

Ranges of Contaminants

\begin{tabular}{llll}
\hline & \multicolumn{1}{c}{ Aluminum } & \multicolumn{1}{c}{ Zirconium } & Stainless Steel \\
$\mathrm{Pu}$ & $0.022 \mathrm{ppb}-3 \mathrm{ppm}$ & $0.001 \mathrm{ppb}-300 \mathrm{ppb}$ & $21 \mathrm{ppb}-35 \mathrm{ppb}$ \\
$\mathrm{Np}-237$ & $1.2 \mathrm{ppm}-2.5 \mathrm{ppm}$ & $1.6 \mathrm{ppm}-4 \mathrm{ppm}$ & $7.4 \mathrm{ppb}-31 \mathrm{ppb}$ \\
$\mathrm{Tc}-99$ & $1.0 \mathrm{ppb}-1.1 \mathrm{ppb}$ & $1.7 \mathrm{ppb}-1.8 \mathrm{ppb}$ & $0.018 \mathrm{ppb}-002 \mathrm{ppb}$
\end{tabular}

\subsection{Conclusions}

The Idaho Chemical Processing Plant produced 32.053 MTU product as the result of processing spent nuclear fuel. Of that amount 25.773 MTU was shipped to Y-12 and 4.076 MTU was sent to Portsmouth. In addition, 0.219 MTU was sent to Rocky Flats, 0.047 MTU was sent to PNNL and 0.168 MTU was sent to Los Alamos. All of the small quantities (less than one metric tonne) were used in criticality experiments. In addition to the material that was shipped off site, there is still in inventory $1.770 \mathrm{MTU}$ of uranium product at ICPP.

There was a total of $30.283 \mathrm{MTU}$ shipped which contained 0.112 grams of plutonium, 24.70 grams of neptunium and 0.028 grams of technetium -99. Y-12 received 0.025 grams of plutonium, 24.34 grams of neptunium and 0.028 grams of technetium. Portsmouth received 0.087 grams of plutonium, 0.127 grams of neptunium and 0.0001 gram of technetium-99. These numbers are our best estimates for this data. They are based on alpha ratio data from analytical measurements at Y-12 and ORIGEN2 code calculations which provided the radionuclide distribution from that data, a calculation can be made that provides an estimate of the transuranic radionuclides present in ICPP product.

Radiologically the dose potential associated with ICPP product and the equipment associated with producing, packaging, and analysis of the product was primarily due to the uranium isotopes in the product and not due to the higher actinides or the technetium-99. The uranium isotopes that limited the potential dose were uranium234 or uranium-235. In some cases, high levels of uranium-236 could become a problem after the ingrowth of uranium-236 daughters - particularly thallium-208. The dose to workers from plutonium isotopes and neptunium-237 while handling ICPP product was at least two orders of magnitude less than that from the uranium isotopes.

In general, because the dose potential from ICPP product was limited by uranium isotopes, operations were conducted in a manner to confine the product and minimize the risk to workers. Radiation monitoring focused on the alpha contamination for worker protection. In addition, added protection was provided through working with the material in glove boxes and hoods. While there were low level exposures and internal exposures through the years, they did not result in any doses in excess of the allowable limits. 
Egli, D., (Ed.) et al., "The Report of the Joint Task Force on Uranium Recycle Materials Processing," DOE/OR-859 (1985)

Foutch, J. L., letter to G. G. Fee, "Proposed Y-12 Plant Specifications for Recycle Material Shipments and Receipts," (October 24, 1985)

Reid, D. G., R. E. Hayden, F. H. Tingey, and V. R. Cooper, "Plant Management," pp 643660, in Reactor Handbook, Second Edition, Volume II, Fuel Reprocessing, S. M. Stoller and R. B. Richards (Editors). Interscience Publishers, Inc., Ney York (1961)

Wenzel, D. R., J. J. Cebe, J. R. Lovell, Radiation Exposure at the Idaho Chemical Processing Plant: 1980. Printed in "Occupational Radiation Exposure in Nuclear Fuel Cycle Facilities. International Atomic Energy Agency Vienna (1980).

Idaho National Engineering Laboratory Historical Dose Evaluation, Vol. I, DOE/ID-12199, Vol. I, August 1991

Croff, A. G. (1980), "ORIGEN2 - A Revised and updated Version of the Oak Ridge Isotope Generation and Depletion Code," ORNL-5621

Henry, R. N. and G. F. Offutt, "Zirconium Fuel Reprocessing Campaign of 1970," USAEC In-1471 (April 1971)

Henry, R. N., C. L. Bendixsen, and R. D. Bradley, "Co-Processing of Zirconium and Aluminum Fuels During 1971," USAEC ICP-1024 (May 1973)

Wheeler, B. R., et al., "Uranium Recovery from Aluminum Alloyed Fuel ICPP Run No. 21," USAEC IDO-14669 (January 1966)

Bjorklund, W. J., et al., "Electrolytic Dissolution Campaign of EBR-II Fuel at ICPP," USAEC ICP-1028 (February 1974)

Bendixsen, C. L., et al., "Zirconium Fuel Reprocessing Campaign of 1971," USAEC ICP1003 (January 1972)

Offutt, G. F., et al., "First Zirconium Alloyed Fuel Reprocessing Campaign Using Soluble Nuclear Poison," USAEC IN-1091 (March 1968)

Bendixsen, C. L., and A. J. Matule, "Uranium Recovery from Aluminum Alloyed Fuel ICPP Run No. 25," USAEC IN-1969 


\section{APPENDIX \\ FLOWSHEETS FOR ICPP PROCESSES}

Flowsheets for each of the processes used to recover uranium are shown in the following figures:

Figure A-1 is the flowsheet for the RaLa process. This process was used to recover barium-140 from freshly irradiated uranium in a fresh MTR fuel element. Even though the total amount of uranium product produced was not significant, it was a significantly different flowsheet from the other flowsheets, all of which used an acidic dissolution reagent. The process operated from 1957 to 1963.

Figure A-2 shows a typical flowsheet for the processing of aluminum clad fuels. It also shows the first cycle extraction process used for these fuels.

Figure A-3 shows a typical flowsheet for the dissolution and first cycle extraction of a typical zirconium clad fuel.

Figure A-4 shows the dissolution process for the dissolution of the EBR-II stainless steel clad fuel.

Figure A-5 shows a typical first cycle extraction for stainless steel fuel from the EBR-II reactor.

Figure A-6 shows the process used to dissolve and blend the zirconium clad fuel dissolver product with the aluminum clad fuel dissolver product.

Figure A-7 shows the flowsheet for the combustion of ROVER graphite-based fuel.

Figure A-8 shows the flowsheet for the dissolution of the ash from the secondary burner in the ROVER fuel combustion flowsheet.

Figure A-9 shows the second and third cycle extraction systems. Stream 11a is the top water scrub used to increase the quality of the product.

Figure A-10 shows the denitrator process for converting the concentrated uranyl nitrate solution into granular dry solid uranium trioxide. Since 1971, this process was used to prepare the final product for shipment as a solid. Prior to 1971, the product was shipped as uranyl nitrate solution in liquid shipping containers (L-10 bottles in a bird cage rack or as L-10 bottles in 110 gallon DOT $6 \mathrm{M} / 2 \mathrm{R}$ shipping drums). 


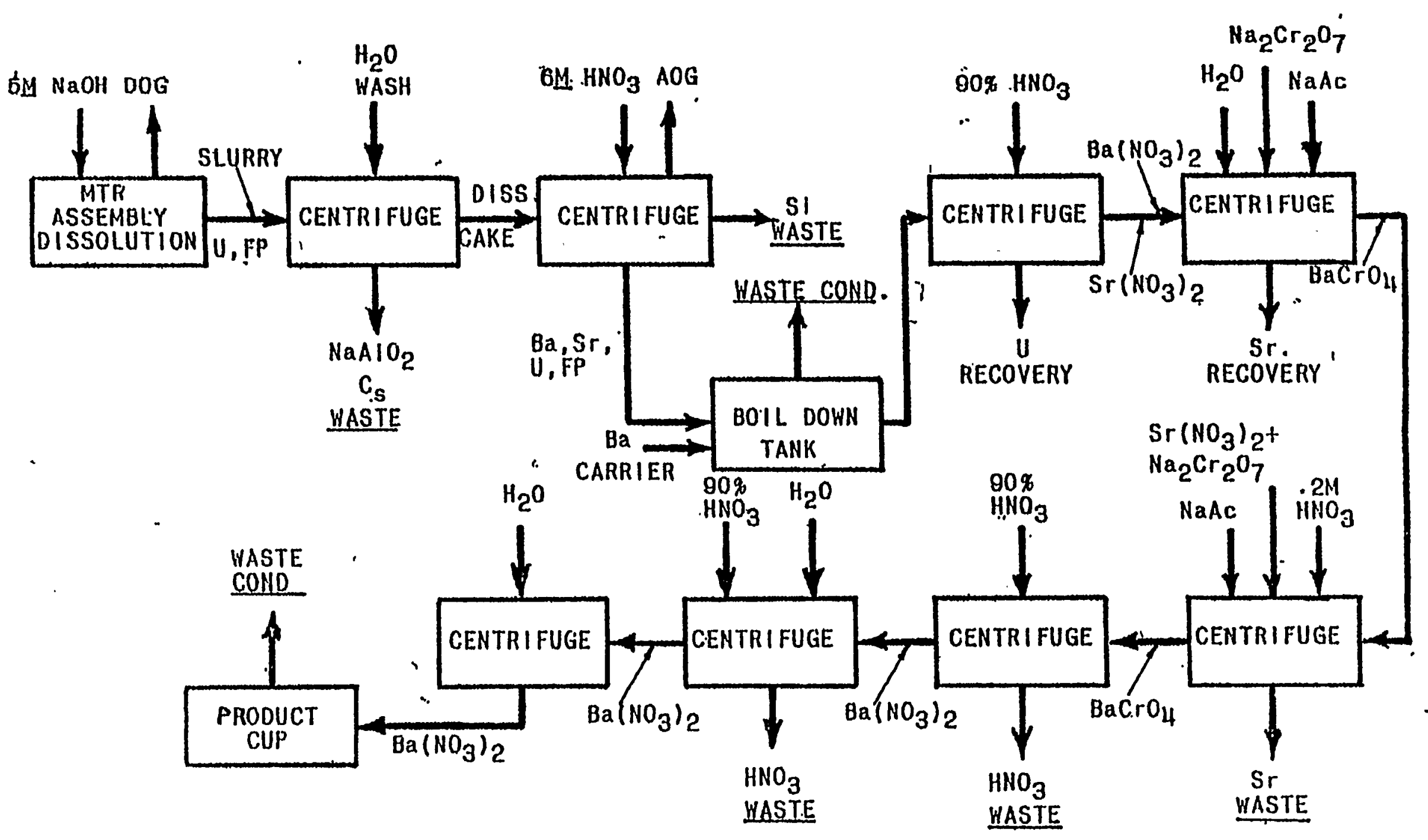

R.a.L.a

SIMPLIFIED CHEMICAL FLOWSHEET 


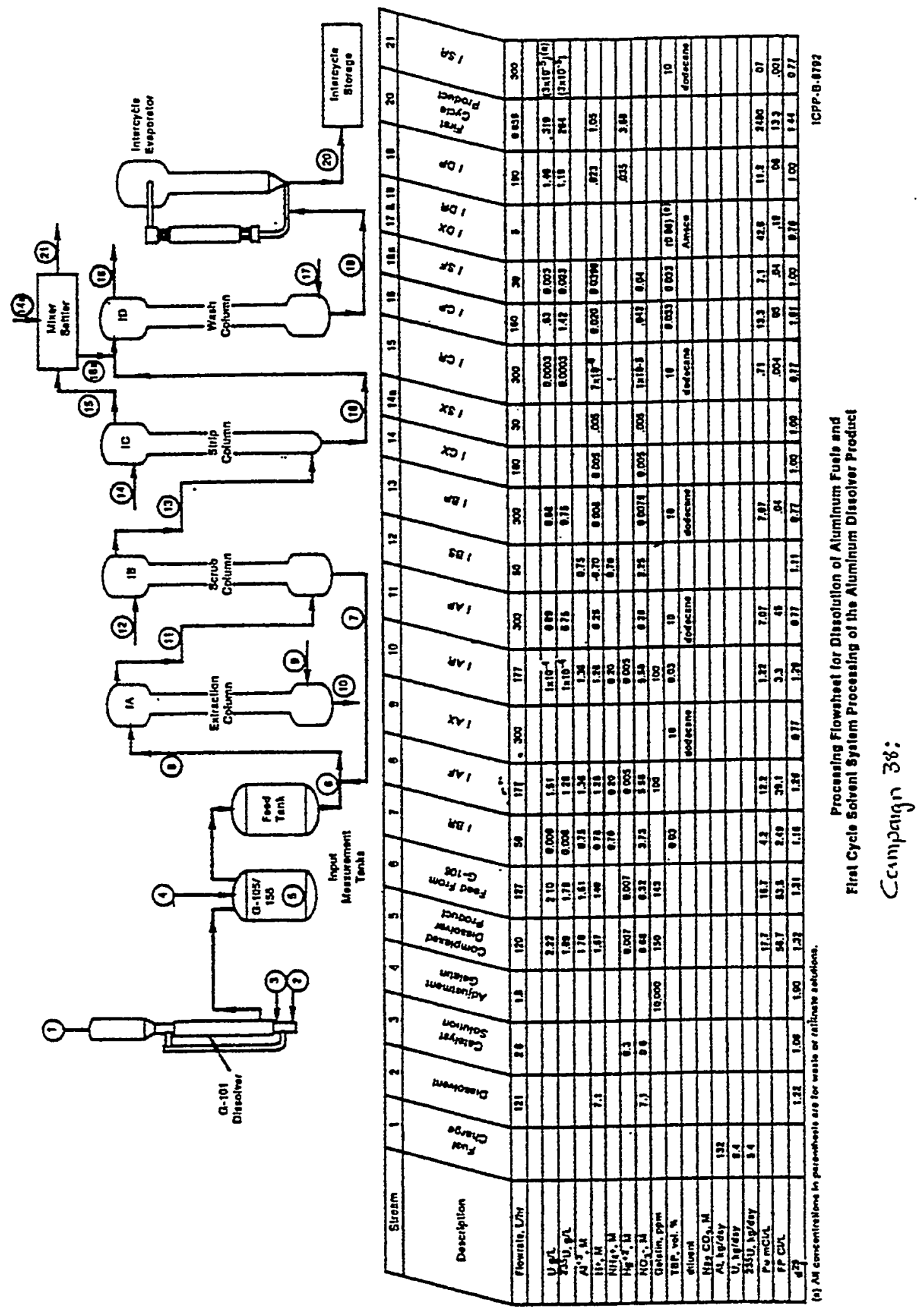

2 


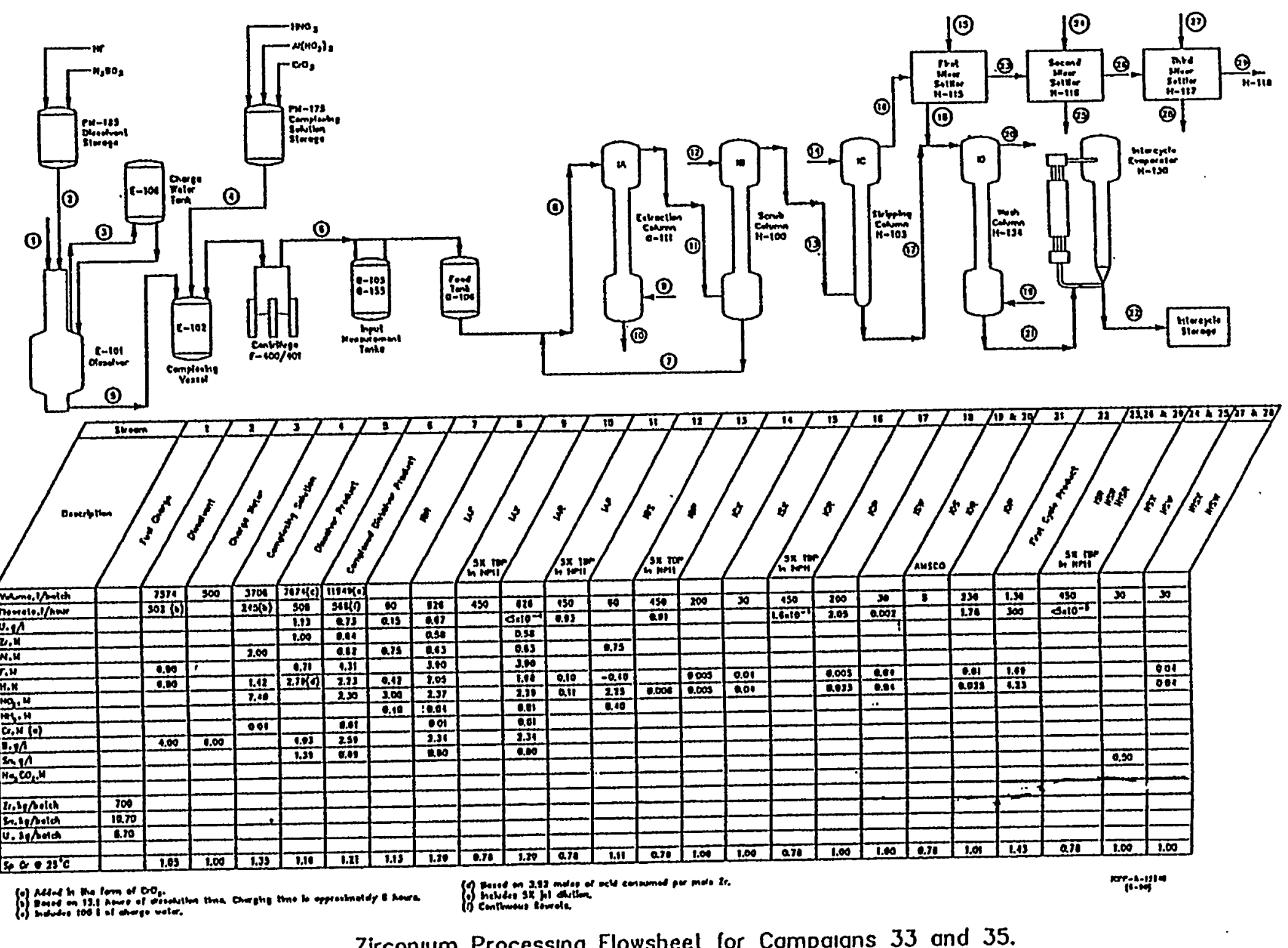

Zirconium Processing Flowsheel for Campaigns 33 and 35. 

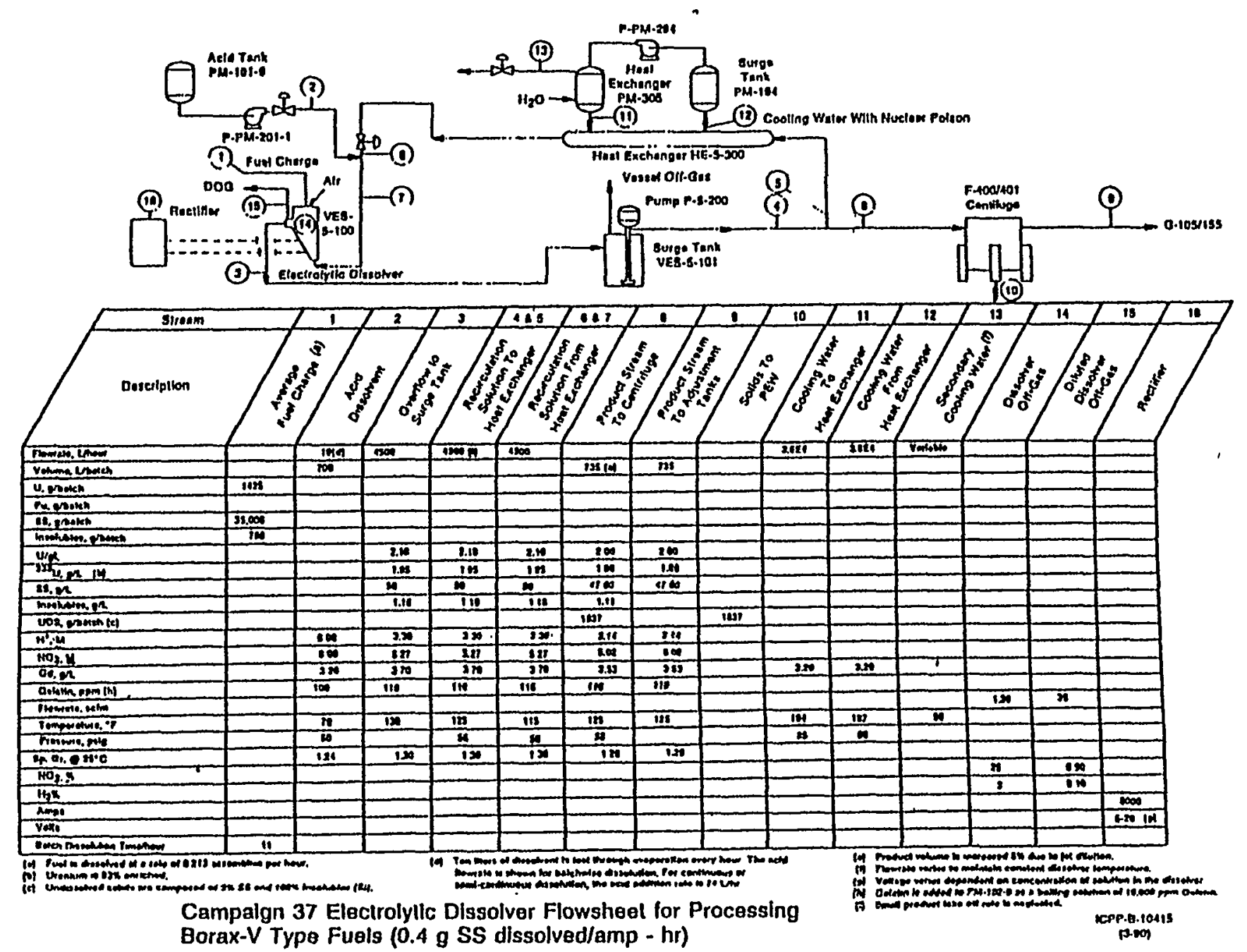


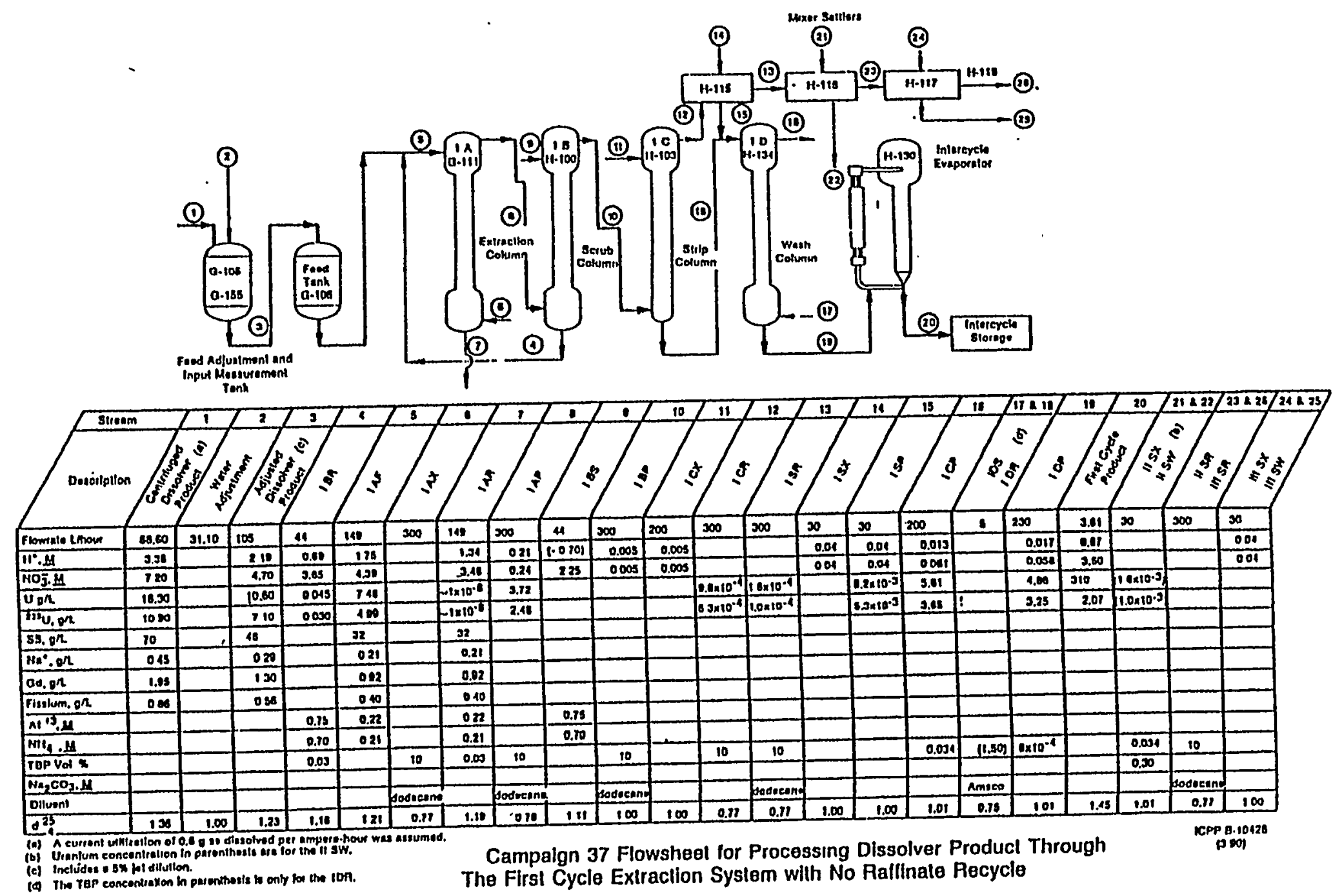



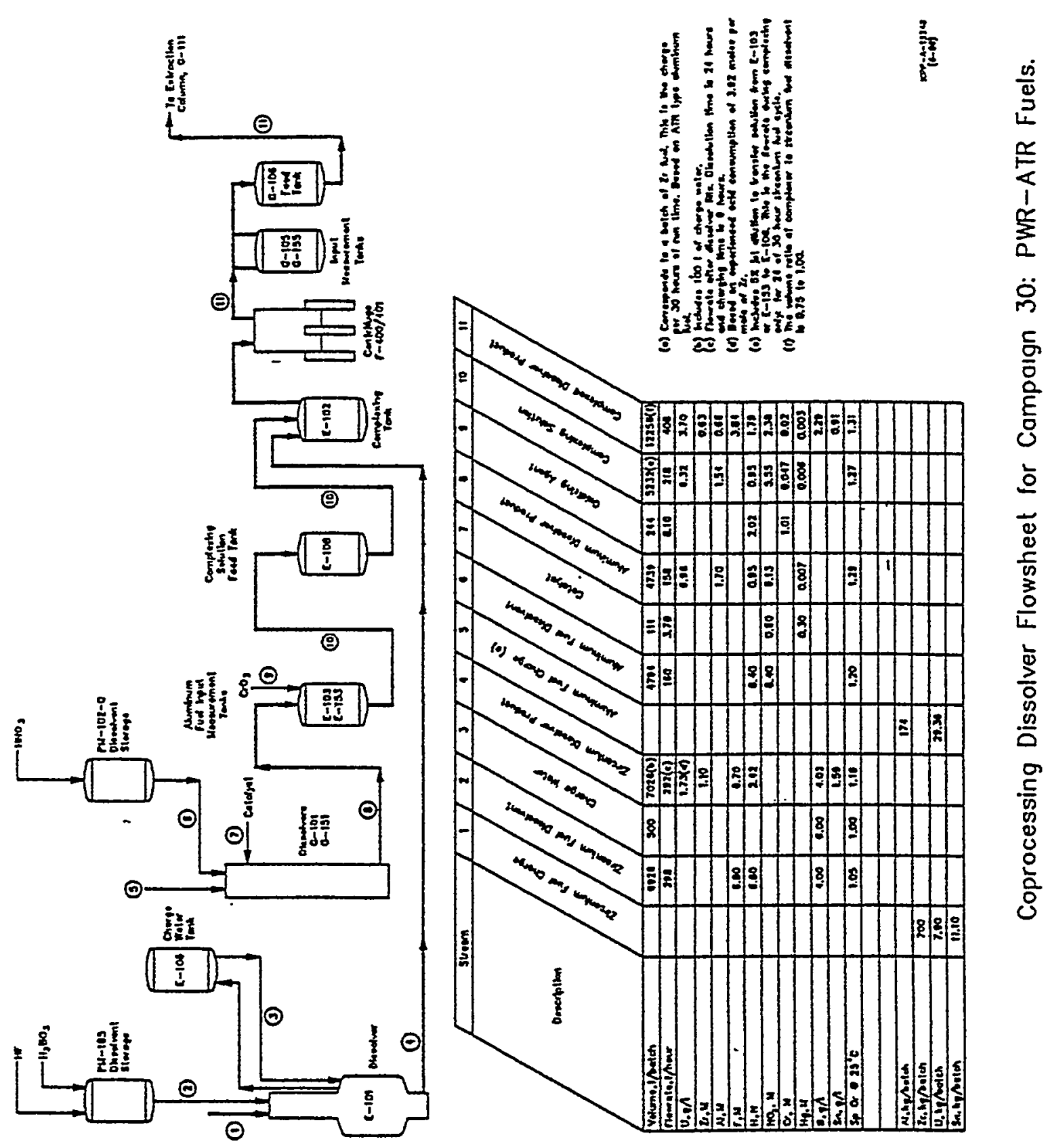


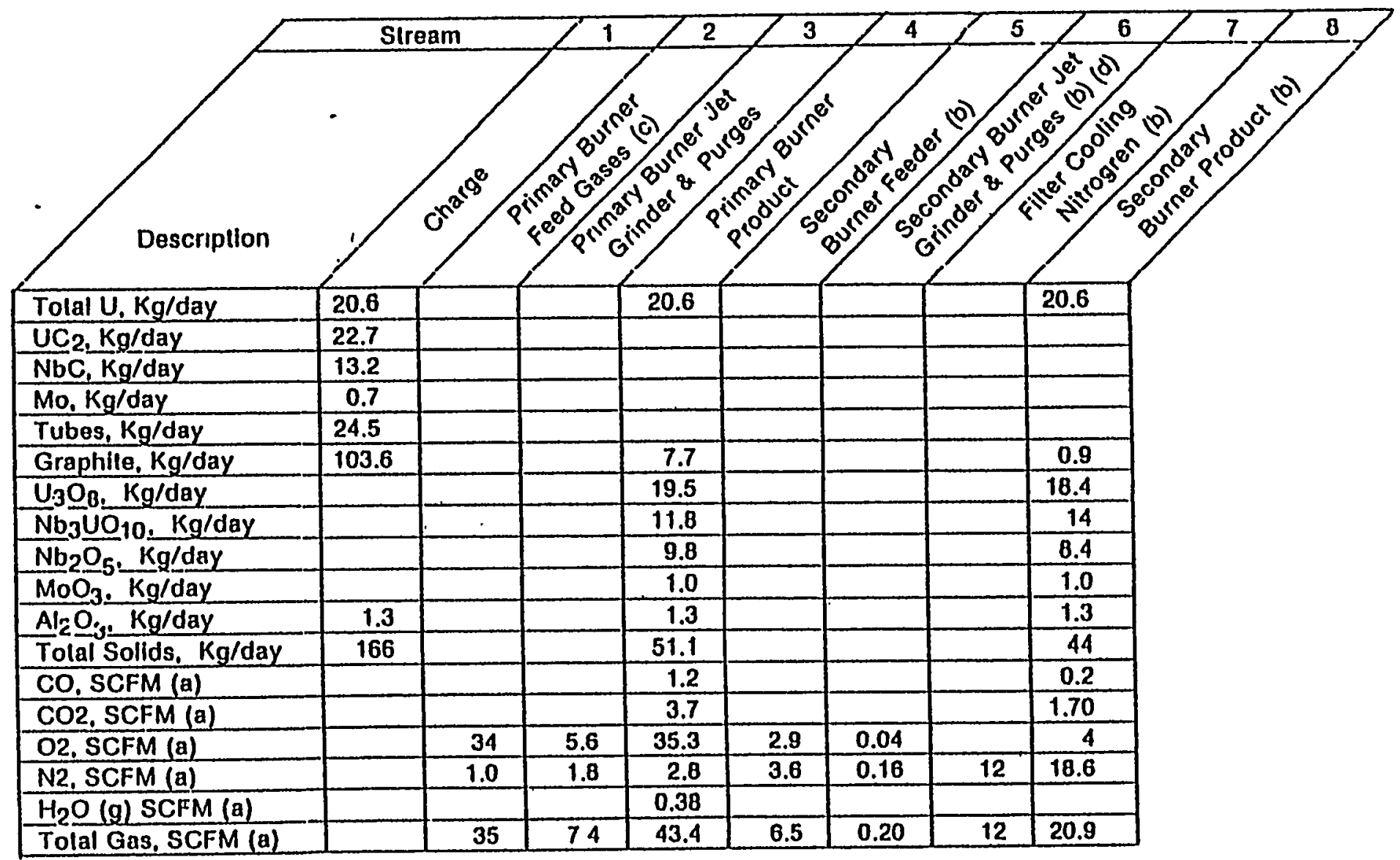

(a) Standard condlitions are $21.1^{\circ} \mathrm{C}$ and 1 almosphere pressure.

(b) The gas llows are averaged lor the period during which burning is occuring in the secondary burner. The Secondary burner is operaled with balches of ash received Irom vessel 103.

(c) The superilcial gas velocilies during burning are $.9 \mathrm{H} / \mathrm{sec}$ with $100 \%$ oxygen and $1.0 \mathrm{~m} / \mathrm{sec}$ with $100 \%$ oxygen for the primary burner and $0.6 \mathrm{ll} / \mathrm{sec}$ lor the secondary burner.

(d) The jel grinders will probably not be used and the gas llow in this llowsheet is only for Instrument purges. If the secondary burner fel grinders are used, a maximum flowrale of 2 SCFM of air could be used. 


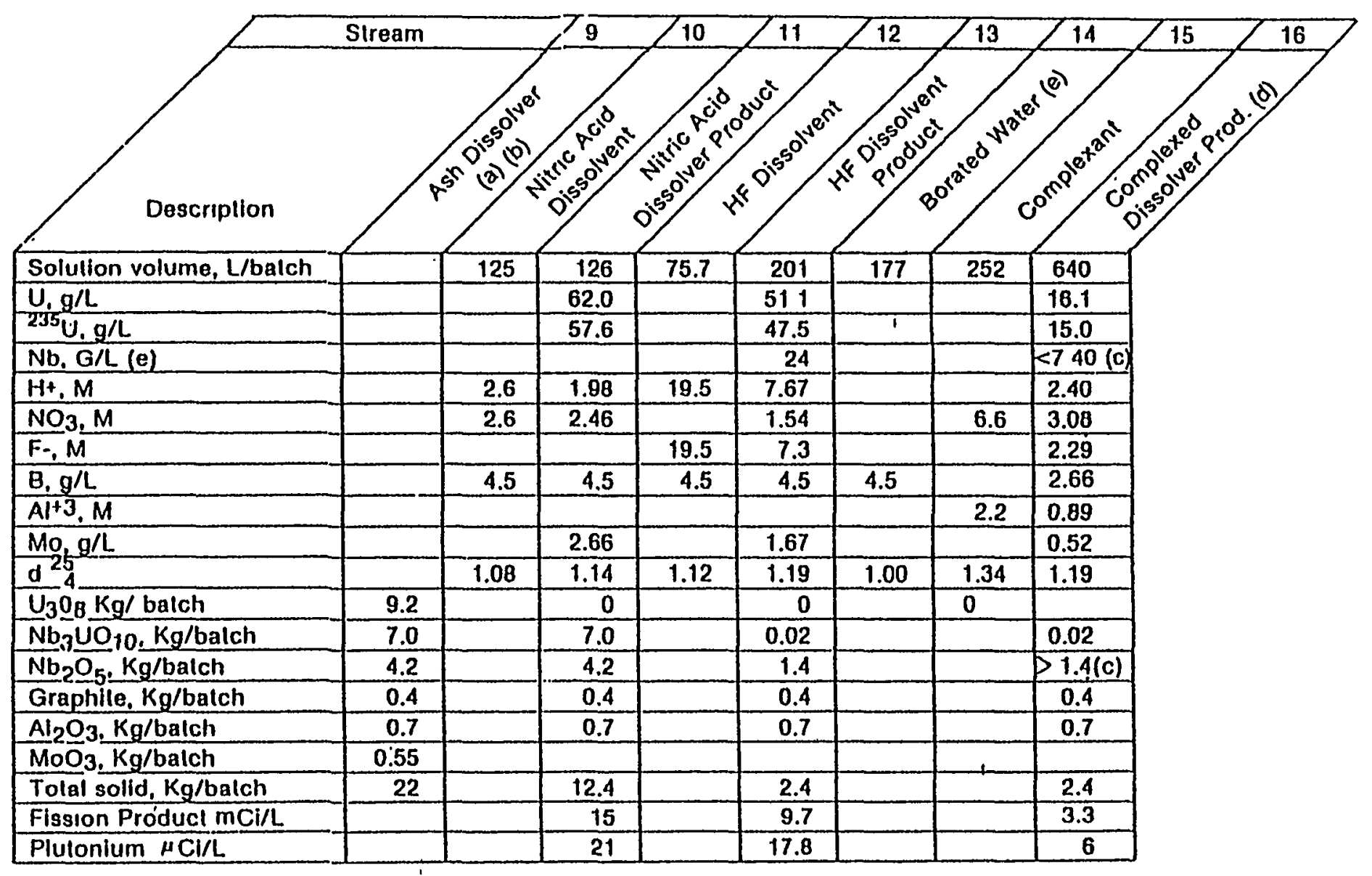

(a) The ash charge will probably be in the range of $161022 \mathrm{Kg}$. The same amounls of reagents should be used II the ash charge is less than $22 \mathrm{Kg}$.

(b) There will be Iwo balches per day added to the dissolver.

(c) Some of the nlobium will precipilale as Nb02F durlng the complexing slep.

(d) Includes 5\% jel dilution for iransler of solulion 13 to the Complexer lank

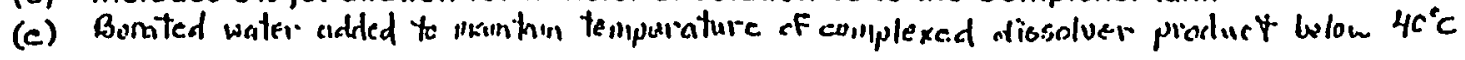

\section{Camprign 37: Flowsheel for Dissolution of ROVER Ash}




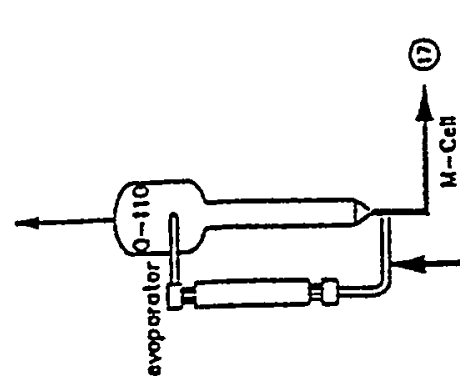

로
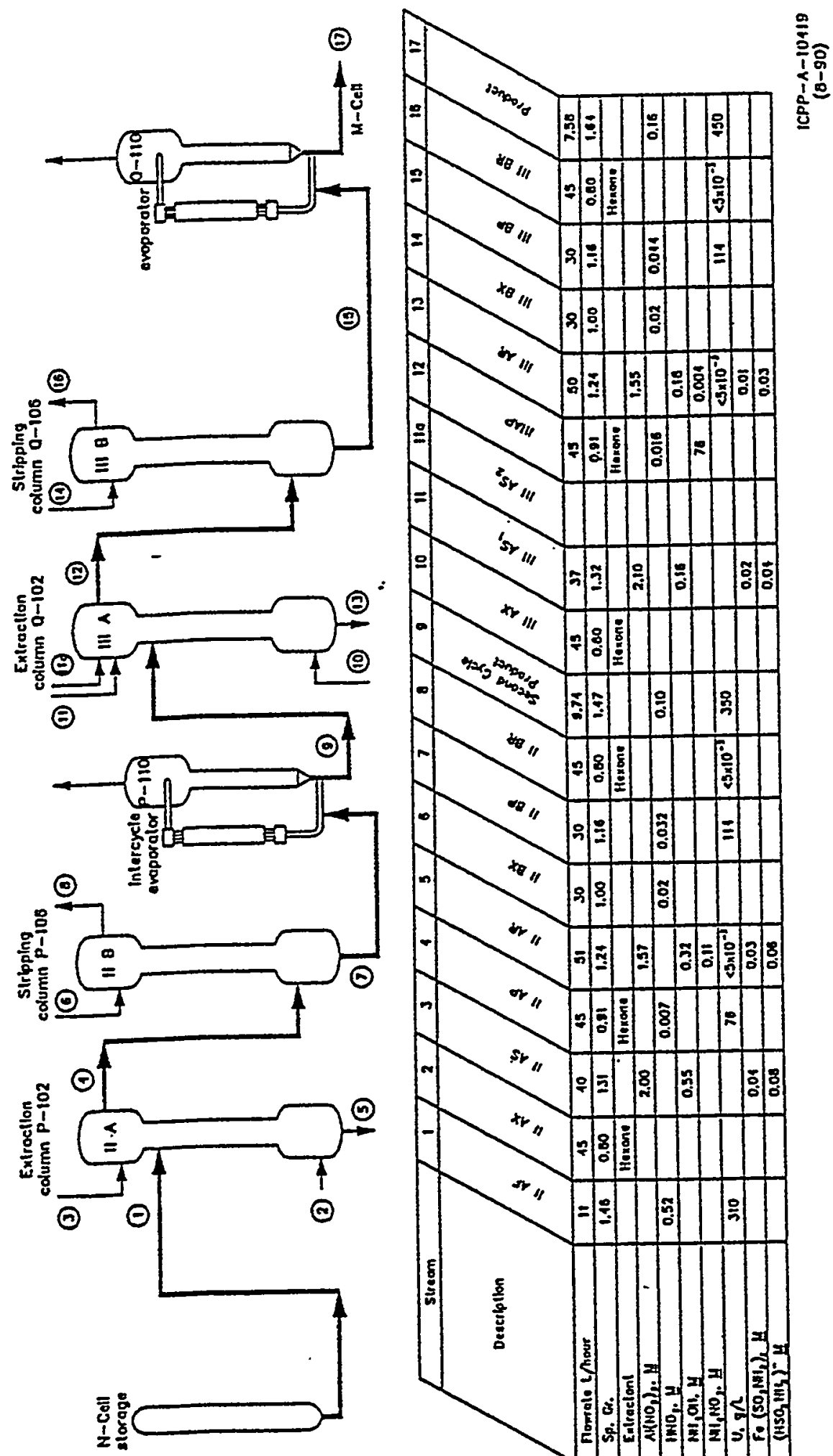

号

는 응

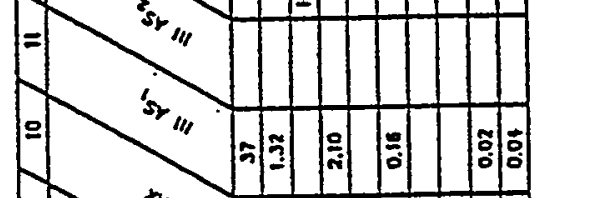

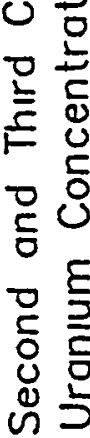

ต产

호을 


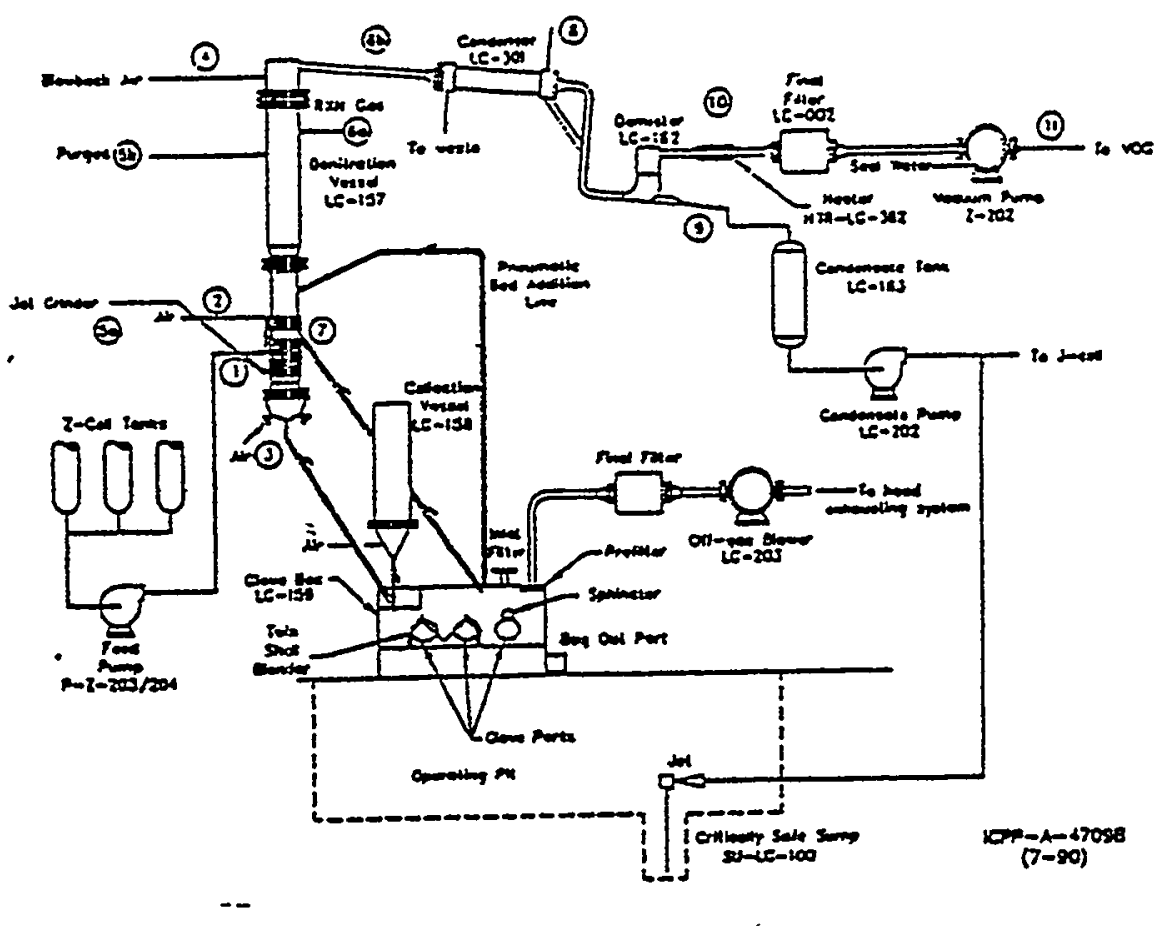

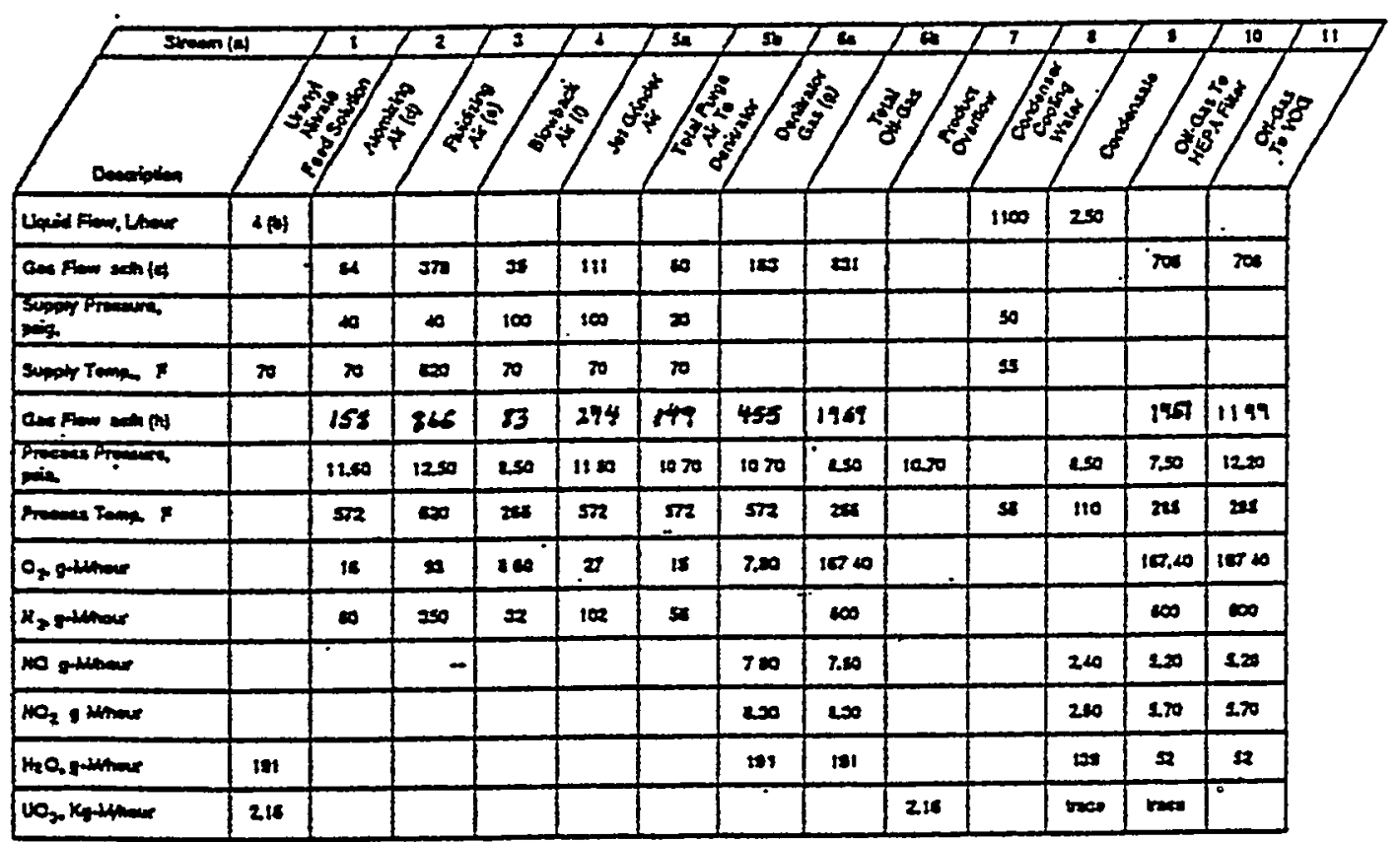

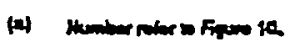

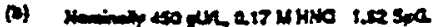

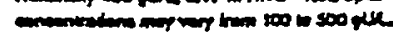

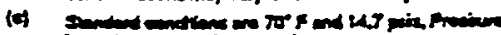

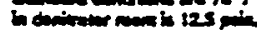

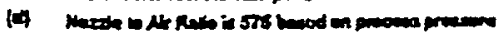

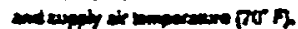

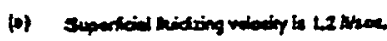

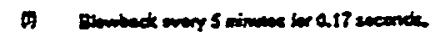

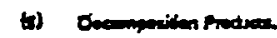

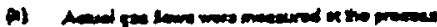

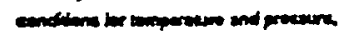




\title{
TRU and DU at SMC
}

\author{
Report on Mass Balance at SMC \\ Don C. Barg
}

June 19,2000

\section{Materials}

The Specific Manufacturing Capability Project (SMC) is located at the north end of the Idaho National Engineering and Environmental Laboratory (INEEL). SMC processes large quantities of depleted uranium (DU) metal. Records show that SMC has received $10,129,000$ pounds of $\mathrm{DU}$ for processing. Of this, $4,726,000$ pounds were received from the Fernald, Ohio, plant, and 5,403,000 pounds were received from the DOE plant at Rocky Flats in Colorado. Approximately 6,385,000 pounds have been shipped to the customer (as of February 29,2000). About 3,750,000 pounds of DU are stored at SMC or are at a recasting facility. This includes incoming material that has not been processed, processed material not yet shipped to the customer, and recyclable DU. Recyclable DU from the processing is sent to a privately contracted metallurgical facility for recasting. This happens from time to time, resulting in an efficient use of the original consignment of DU.

In addition to the material shipped, SMC produces an unavoidable quantity of waste DU material. This consists of laser fines (residues from laser cutting of the DU), and DU oxides from processes such as a water wash of processed material, sweepings, and so on. A best estimate of the quantity of waste material as of the end of February 2000 is approximately 93,000 pounds of DU. Roughly half of the laser fines have been shipped for re-use. The remainder of the material remains at SMC.

SMC uses a single HEPA-filtered stack emissions system, with post-filter monitoring for any effluent releases. Data for 1985-1989 are not presently available, and the final report for 1999 is not yet complete. Based on the data for 1990-1998, and normalizing this to the entire duration of the project, SMC has released approximately 0.25 pound of DU to the atmosphere from the beginning of the project to the present day. This is a negligible amount of material. DU and DU oxides are heavy and dense. No environmental sample collected outside the SMC fence has ever detected any DU from SMC.

The DU at SMC is $0.2 \%$ by weight $U-235$, about $0.0005 \%$ by weight $U-234$, and nearly all the rest is U-238. Small quantities of other elements, such as carbon, nickel, iron, zirconium, silicon, titanium, and aluminum have been reported in the "parts per million" range. The highest aggregate of these trace elements has been about $290 \mathrm{ppm}$. 


\section{Transuranics and Fission Products}

In August of 1999 it was reported to SMC that low concentrations of transuranic and fission product materials could be present in the DU used at SMC. Some very limited samples where data already were available were evaluated, and Am-241, Pu-238, and Pu$239 / 240$ were found to be present. These first samples were not analyzed for Np-237 or Tc-99. The results suggested that a systematic sampling of available DU billets would provide useful information. Sixty samples were therefore collected from DU billets located at SMC: 20 from billets remaining from the original consignment (referred to as Population \#1); 30 from the first recasting (Population \#2); and 10 from the second recasting (Population \#3). Approximately half of the Population \#1 samples were from Rocky Flats billets, and the others were from Fernald billets. The results were reported to SMC in BBWI Internal Report INEEL/INT-99-01228, dated December 15, 1999. A qualitative analysis of the results has shown that there is no tendency for TRU or Tc-99 to migrate either to the upper portion of billets or to the lower portion. The only variation is random and is neither chemically nor physically driven. A second, more complete statistical analysis (INEEL Internal Memo JJE-00-01) shows that TRU quantities are quite consistent throughout the TRU measurements (with statistically likely random outliers being present). The Tc-99 concentrations are far more widely distributed. Maximum, minimum, and average values for the various radioactive materials are listed in Table 1. This table lists values both in terms of $\mathrm{pCi}$ per gram of DU and of grams of material per gram of DU. The values given in Table 1 are taken from INEELINT9901228.

Table 1

\begin{tabular}{|c|c|c|c|c|c|c|}
\hline Nuclide & & $\mathrm{pCi} / \mathrm{g}$ & & & $\mathrm{g} / \mathrm{g}$ & \\
\hline & maximum & minimum & Average & Maximum & Minimum & Average \\
\hline $\mathrm{Np}-237$ & 3.73 & 1.14 & 1.82 & $5.29 \mathrm{E}-09$ & $1.62 \mathrm{E}-09$ & $2.58 \mathrm{E}-09$ \\
\hline $\mathrm{Pu}-238$ & 2.05 & 0 & 0.272 & $1.20 \mathrm{E}-13$ & 0 & $1.59 \mathrm{E}-14$ \\
\hline $\mathrm{Pu}-239 / 240$ & 2.66 & 0 & 0.406 & $4.28 \mathrm{E}-11$ & 0 & $6.55 \mathrm{E}-12$ \\
\hline $\mathrm{Am}-241$ & 19.24 & 0 & 2.78 & $5.61 \mathrm{E}-12$ & 0 & $8.10 \mathrm{E}-13$ \\
\hline $\mathrm{Tc}-99$ & 537 & 64 & 154 & $3.16 \mathrm{E}-08$ & $3.78 \mathrm{E}-09$ & $9.06 \mathrm{E}-09$ \\
\hline
\end{tabular}

The average value of the combined TRU material is 2.59 E-09 gram of TRU per gram of $\mathrm{DU}$, or 2.59 parts per billion (ppb), and the maximum combined value of TRU per gram of DU is $5.34 \mathrm{ppb}$. Technetium-99 is also in the ppb range, as shown.

Processing of DU at SMC consists of rolling and cutting billets. These processes do not affect TRU concentrations in any way.

In the recasting process, the decay products (Th-234 and Pa-234m) move to the top of the molten DU and are skimmed off in slag. However, the TRU isotopes are nearly the same atomic weight and chemical characteristics as uranium. TRU is neither concentrated nor diluted in the recasting process, and no chemical processing beyond recasting takes place. SMC requires that only SMC metallic DU be used in the recasting process, and records of 
materials returned to SMC affirm that this material is exclusively for the SMC process. SMC Quality Engineers and Inspectors make at least two visits to the recasting facility annually for overall quality control. These visits also confirm that no processing or additions are made to SMC DU. No change in concentrations from recasting or SMC processing has been observed, or is expected. Samples from the original shipment, from the first recasting, and from the second recasting have not shown a significant reduction in the amount of TRU or Tc-99 present in the samples.

\section{Dose Evaluation}

Derived Air Concentrations (DAC) for TRU materials are reported as 0.0067 of the DAC for uranium isotopes (see 10 CFR 835, Appendix A). The DAC is defined as the atmospheric concentration of a nuclide that, if breathed continuously at a standard breathing rate for a full working year of 2000 hours per year, could result in an internal committed effective dose equivalent (CEDE) of $5000 \mathrm{mrem}$. The estimated dose from inhalation of DU with the TRU constituents reported is calculated to increase by a factor of 0.0022. The derivation of this factor is shown in Appendix A of this report. Stated more clearly, a person who receives an internal dose (over 50 years) of 100 mrem CEDE from an intake of DU would have an additional internal dose from the intake of TRU in the DU, of 0.22 mrem. Such a dose is less than the statistical fluctuations inherent in sampling, counting, and evaluation.

SMC has conducted an extensive bioassay program since the earliest days of the project. At first, fecal samples were collected. No positive results were ever obtained. SMC also asked employees to be counted in a whole-body counter and lung counter. This also provided only negative results. At the same time, employees were asked to submit urine samples for analysis. Using state-of-the-art technology, the urine samples detected low concentrations of uranium in some individuals, at levels far below the minimum detectable levels for whole-body counting. The INEEL Internal Dosimetry Technical Basis Document, published in 1999, gives Minimum Detectable Activities for plutonium nuclides. The MDA for Pu-239/240 is $2.7 \mathrm{E}-08 \mu \mathrm{Ci} / \mathrm{ml}$. This could give an estimated dose of 48 mrem CEDE. No plutonium or other TRU uptakes have ever been detected by any system at SMC. The urine bioassay program has continued throughout the duration of the SMC project.

During 1999 the maximally exposed SMC worker received an internal dose from inhalation of DU, of 48 mrem CEDE. The urine sample with the maximum single result was also analyzed for the possible presence of plutonium. The reported result was below the statistical variation, and no plutonium dose could be assigned. This agrees with the evaluation described in Appendix A. SMC does not currently collect fecal data for analysis. The reported results of this bioassay sample are attached to this report.

The maximum internal dose received at SMC was about 150 mrem CEDE, in 1988. This was from DU only. Based on the information presently available, an additional calculated dose of 0.3 mrem would be assigned to this individual from TRU/Tc-99. 
The maximum number of employees at SMC is about 500, in the late 1980s. Presently the employee population is about 225. It is estimated that between 1000 and 1500 people may have been employed at SMC over the life of the project to the present time. Not more than half of these have been potentially exposed to DU and its constituents.

\section{Licensing}

The recasting facility holds an NRC agreement state license to receive, process, and ship depleted uranium. In 1999, when the TRU issue was raised, the state authorized the facility to continue to possess DU through January 2000. This gave SMC and the recasting facility time to collect and evaluate samples. Based on the SMC evaluation submitted to the recasting facility and through them to the state and NRC, the license authorization has been extended until March 31,2002. This is the original date of expiration for this license. The NRC and the state continue to evaluate the TRU/FP situation. 


\section{APPENDIX A}

\section{Increase in Dose from the Presence of Transuranics in Depleted Uranium}

Table 1 of this report lists the average concentration of the various TRU components of DU. Each is listed in pCi of TRU per gram of DU. The sum of these averages is 5.288 $\mathrm{pCi} / \mathrm{g}$. The specific activity of $\mathrm{DU}$ is $3.6 \mathrm{E}-07 \mathrm{Ci} / \mathrm{g}$. Therefore the activity concentration of TRU in DU, in units of curies of TRU per curie of DU, is

$$
\begin{aligned}
& \frac{5.288 \mathrm{pCi} / \mathrm{g}_{\mathrm{DU}}}{3.6 \mathrm{E}-07 \mathrm{Ci} / \mathrm{g}_{\mathrm{DU}}}=1.47 \mathrm{E}+07 \mathrm{pCi} / \mathrm{Ci} \\
& =1.47 \mathrm{E}-05 \mathrm{Ci} \text { of TRU per Ci of DU }
\end{aligned}
$$

The Derived Air Concentration (DAC) for TRU nuclides is $2 \mathrm{E}-12 \mu \mathrm{Ci} / \mathrm{ml}$, and the DAC for uranium nuclides is $3 \mathrm{E}-10 \mu \mathrm{Ci} / \mathrm{ml}$. The $\mathrm{DAC}$ is defined as the atmospheric concentration of a nuclide that, if breathed at a standard breathing rate for a full working year of 2000 hours, would result in an internal committed effective dose equivalent (CEDE) of $5000 \mathrm{mrem}$. So for equal amounts of DU and TRU in the body, the TRU gives an effective dose equivalent 150 times more than the $\mathrm{DU}$.

As shown above, the total TRU activity in the DU at SMC is far below the DU activity. The effect of TRU on internal dose is found by multiplying the fractional activity of TRU as given in Equation (1) by 150. This gives

$$
1.47 \mathrm{E}-05 \mathrm{Ci} / \mathrm{Ci} \times 150=2.20 \mathrm{E}-03
$$

That is, for every rem of internal dose received from the DU at SMC, an additional 2.2 mrem of dose is received from TRU. An internal dose of $100 \mathrm{mrem}$ would be increased to $100.22 \mathrm{mrem}$, and so on.

Table 1 also lists the maximum TRU concentrations in DU. To provide an upper bound to the possible increase in dose from TRU a second evaluation is needed.

The sum of the maximum TRU concentrations is $27.68 \mathrm{pCi} / \mathrm{g}$ (picocuries of TRU per gram of DU). All other factors in the above calculation remain constant. Therefore the internal dose for the maximum concentration case should be 27.68/5.288 of the dose for the average concentration. So for the maximum concentration, a dose amounting to 1 rem CEDE from DU alone would be increased to $11 \mathrm{mrem}+1 \mathrm{rem}$, or $1011 \mathrm{rem}$. This is still only about a $1 \%$ increase in dose.

Although the mass fraction of Am-241 in TRU is less than the mass fractions of the other TRU nuclides, the activity fraction of Am-241 is significantly greater than the activity fractions of the other nuclides. Am-241 has over half of the total TRU activity in the samples collected at SMC. Am-241 is therefore the most restrictive isotope in the TRU 
materials at SMC. Because of this it is desirable to give a separate analysis for Am-241. Only the maximum concentration will be discussed.

The maximum activity concentration of Am-241 in the DU samples at SMC was $19.2 \mathrm{pCi}$ of Am-241 per gram of DU. The other factors in the calculations used for total TRU remain constant. We have

$$
\begin{aligned}
& \frac{19.24 \mathrm{pCi} / \mathrm{g}_{\mathrm{DU}}=}{3.6 \mathrm{E}-07 \mu \mathrm{Ci} / \mathrm{gDU}_{\mathrm{DU}}}=5.34 \mathrm{E}+07 \mathrm{pCi} / \mathrm{Ci} \\
& =5.34 \mathrm{E}-05 \mathrm{Ci} \text { of } \mathrm{Am}-241 \mathrm{per} \mathrm{Ci} \text { of } \mathrm{DU}
\end{aligned}
$$

Again, the DAC for Am-241 is $2 \mathrm{E}-12 \mu \mathrm{Ci} / \mathrm{ml}$, and the DAC for uranium nuclides is $3 \mathrm{E}$ $10 \mu \mathrm{Ci} / \mathrm{ml}$. So the effect of Am-241 on internal dose is found by multiplying the fractional activity of $\mathrm{Am}-241$ by $(3 \mathrm{E}-10 / 2 \mathrm{E}-12)=150$. This gives

$$
\text { - } 5.34 \mathrm{E}-05 \mathrm{Ci} / \mathrm{Ci} \times 150=8.01 \mathrm{E}-03
$$

The maximum concentration of Am-241 observed at SMC could therefore increase a one rem dose from DU, to $1.008 \mathrm{rem}$. This is less than a $1 \%$ increase.

The TRU found in DU at SMC thus contributes a negligible addition to the dose received from the DU itself. 


\section{APPENDIX B \\ Increase in Dose from the Presence of Tc-99 in Depleted Uranium}

The average concentration of the Tc-99 constituent in DU is listed as $154 \mathrm{pCi}$ of TC-99 per gram of DU. As stated in Appendix A, the specific activity of DU is $3.6 \mathrm{E}-07 \mathrm{Ci} / \mathrm{g}$. The activity concentration of Tc-99 in DU is

$$
\begin{aligned}
& \frac{154 \mathrm{pCi} / \mathrm{gDU}_{\mathrm{DU}}}{3.6 \mathrm{E}-07 \mathrm{Ci} / \mathrm{gDU}_{\mathrm{DU}}}=4.28 \mathrm{E}+08 \mathrm{pCi} / \mathrm{Ci} \\
& =4.28 \mathrm{E}-04 \mathrm{Ci} \text { of } \mathrm{Tc}-99 \text { per } \mathrm{Ci} \text { of } \mathrm{DU}
\end{aligned}
$$

The DAC for Tc-99 is $3 \mathrm{E}-07 \mu \mathrm{Ci} / \mathrm{ml}$, and the DAC for uranium nuclides is $3 \mathrm{E}-10$ $\mu \mathrm{Ci} / \mathrm{ml}$. So for equal amounts of DU and Tc-99 in the body, the Tc-99 gives an effective dose equivalent only 0.001 of the DU.

As shown above, the total Tc-99 activity in the DU at SMC is far below the DU activity. The effect of Tc-99 on internal dose is found by dividing the fractional activity of Tc-99 as given in Equation (3) by 1000. This gives

$$
\text { 4.28 E-04 Ci/Ci } \div 1000=4.28 \mathrm{E}-07
$$

That is, for every rem of internal dose received from the DU at SMC, an additional 0.43 microrem $(\mu \mathrm{rem})$ is received from Tc-99.

The maximum concentration of Tc-99 in DU is listed as $537 \mathrm{pCi} / \mathrm{g}$. The dose from the maximum concentration of Tc-99 should be increased (over that from the average concentration) by a factor of 537/154. Therefore, for a dose of 1 rem CEDE from DU alone, the additional dose for the maximum concentration of Tc-99 would be 1.5 microrem ( $\mu \mathrm{rem})$.

The Tc-99 found in DU at SMC thus contributes a negligible addition to the dose received from the DU itself. 


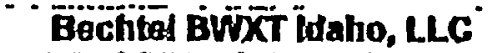 \\ BIOASSAY LABORATORY \\ SAMPLE RECORD SHEET - ACTINIDES}

Name:

URGENT

Tracking Number: 00002954

S Number:

Organizalion:

Area Abbreviation: SMC

Sample Type: Urine

Quanlity: $\quad 400.00 \mathrm{~mL}$

Date \& Hout Sampled: 8/9/1999 1200

Sample Sont: 10/26/1999

Sample Recelved: 10/26/1999

Electronically Approved by

Handcopy prepared on .11/3/189g

Comments: WAS 99H096 TOTAL U - PUIU REQUESTED 10/26/98 AFTER POSTTIVE RESULT

\begin{tabular}{|c|c|c|c|c|}
\hline Isolopes(s) & Results \pm Rnd" ; Tot* & MDA $^{* 4}$ & Units & Analyst \\
\hline Punzas & $(+2 \pm 5 ; 5) E-08$ & $+3.49 \mathrm{a}-9$ & pCilspl & ARB \\
\hline Pu-239/240 & $(-0.4 \pm 5.8 ; 6.2) E-09$ & $+3.50 e-9$ & & \\
\hline$A m-241$ & & & & \\
\hline$U-233 / 234$ & $(+2.0 \pm 0.2 ; 0.4) E-07$ & $+1.03 e \cdot 8$ & $\mu C V_{6 p l}$ & ARB \\
\hline$U_{2235 / 236}$ & $(+8 \pm 6 ; 7) E-09$ & $+6.070-9$ & & \\
\hline$U_{-238}$ & $(+1.0 \pm 0.0 ; 0.2) E-06$ & $+8.710-9$ & & \\
\hline
\end{tabular}

- "Rnd" Is the estimated random uncertainty, reported as one standard devfation, 1s. Tot" is the estimated total uncertalnty, also reported as 1s.

Small regalive and olter results $=2$ 2"Tot are Interpreled by LMITCO as including "zero" or as Not Detected.

For results greater than $2^{2} T$ Tot but $<=3^{*}$ Tot, detection is quesilionable. Results greater than $3^{2}$ Tol indicate detection.

* Mknimum Delectable Amtount. Based on ANSI 13.30 Standand equaflons. 


\title{
SMC BILLETS
}

\section{TNTEC RADIOCHEMISTRY}

$-$

\author{
Troy Tranter \\ Dean Goodwin \\ Mike Evans \\ Ron Stone \\ Stacey Hill \\ Doug Thompson \\ Chris Oertel
}

\section{Idsho National Engineering and Eavironmental Loboratory \\ P.O. Box 1625 \\ Idaho Falls, Idaho 83415-3885}

Wednesday, December 15, 1999 


\section{CASE NARRATIVE}

\section{Introduction}

The material analyzed for this project consisted of samples of depleted uranium metal received from the SMC manufacturing process

Results presented in this report include values for the following isotopes:

${ }^{237} \mathrm{~Np},{ }^{238} \mathrm{Pu},{ }^{239} \mathrm{Pu}{ }^{210} \mathrm{Pu},{ }^{99} \mathrm{TC}$ and ${ }^{241} \mathrm{Am}$.

Following this narrative, the sections will include:

- Summary Data Pages (Form I)

- QA/QC Summary (Form II \& III)

\section{Sample Dissolution}

Aliquots of the uranium metal ( $\equiv 2$ grams) were dissolved in batch contacts using approximately $50 \mathrm{~mL}$ of reagent grade $6 \mathrm{M} \mathrm{FNO}_{3}$ and minimal heat. After dissolution and cooling, the samples were diluted to volume in a $50 \mathrm{~mL}$ volumetric flask with 17 $\mathrm{Mohm} \mathrm{DI} \mathrm{H}_{2} \mathrm{O}$. The samples were mixed well and small aliquots were removed for acid titration. This tirration was performed to obtain a quantitative acid value for reference in the chemical separation procedures.

\section{Plutorium Isotopes}

Aliquots of the dissolution were removed from the primary solution and adjusted to 2.5 $\mathrm{M} \mathrm{HNO}_{3}$ with $\mathrm{DI} \mathrm{H}_{2} \mathrm{O}$. These aliquots were spiked with ${ }^{236} \mathrm{Pu}$ or ${ }^{262} \mathrm{Pu}$ rracer and the oxidation state of the plutonium was adjusted to $\mathrm{Pu}^{\text {th }}$. The plutonium was then chemically separated from the rest of the matrix via excraction chromatography, $\mathrm{Nd}^{+3}$ and FF were added to the stripped solution and the plutonium was co-precipitated with NdF, as $\mathrm{PuF}_{4}$. The precipitate was collected onto a 0.1 micron filer and dried. The filter was analyzed by alpha spectrometry (Ortec Soloist counters coupled to Sun Mierosystems workstation) and the plutonium isotope concentrations were quantified. All values wers corrected for chemical yield via the Pu tracer and are reported in units of dps/g of sample.

After dissolution, a subset of the samples was filtered through a 0.2 micron filter to remove any insoluble oxides of plutorium that might be present. These filters were then put into solution by high temperature fusion and plutonium was separated and analyzed by the method previously described. These results are repozred in units of dps/g of sample and are desigrated with an asterisk in the Sumary Data Report (Form I). 
Nepmanivim-237

Aliquots of the dissoluvion were removed from the primary solution and adjusted to 2.5 $\underline{\mathrm{M}} \mathrm{HNO}_{3}$ with $\mathrm{DI} \mathrm{H} \mathrm{H}_{3} \mathrm{O}$. The oxidation state of the neptunium was adjusted to $\mathrm{Np}^{+4}$ and the sample was passed through an extraction chromatography column to extract neptunium. The neprunium fraction was eluted and this solution was used for the quantitative determination of ${ }^{237}$ Np by ICPMS (VG Plasma Quad PQ+). Neptunium-239 Was also used as a tracer to determine analyrical yield through the separation procedure. The ${ }^{239} \mathrm{~Np}$ was determined by gamma spectroscopy prior to ICPMS analysis and this value was used to correct for chemical loss in calculation of the final ${ }^{237} \mathrm{~Np}$ result. The neptunium values are reparted as dps/g of sample.

\section{Amercium-241}

Aliquots of the dissolution were removed from the primary solution and adjusted to 2.5 $\mathrm{M} \mathrm{HNO}_{3}$ with $\mathrm{DI} \mathrm{H}_{2} \mathrm{O}$. These aliquots, were spiked with ${ }^{24} \mathrm{Am}$ tracer and then chemically separated from the rest of the matrix via extraction chromatography. The americium fraction was eluted from the extraction column and $\mathrm{Nd}^{+3}$ and HF were added to the stripped solurion to co-precipitate the americium as $\mathrm{AmF}_{3}$. The precipitate was collected onto a 0.1 micron filter and dried. The filter was analyzed by alpha spectrometry (Ontec Soloist counters coupled to Sun Microsysterns workstation) and the ${ }^{441}$ Am isotope concentration was quantified. All values were corrected for chemical yield via the ${ }^{243} \mathrm{Am}$ tracar and are reported in units of dps/g of sample.

\section{Technetium-99}

Aliquots of the dissolution were retnoved and diluted by a factor of 100. ${ }^{115}$ Indium was added to give a final solution concentration of 100 ug $\mathcal{L}^{115}$ In in all samples and standands. All determinations were performed via ICPMS (VG Plasma Quad PQ+) and values are reported in units of dps/g of sample.

- Technetium suffers from an isobaric interference with " $\mathrm{Ru}$ and a molecular interference due to Mo(98)Hit. Ruthenium and ${ }^{98} \mathrm{Mo}$ were monitored on all samples. Rutheniuen was not detected in the samples at mass 102 or 104. Molybdenura was detected in some samples ar mass 98 , but not at levels requiring a correction.

\section{Gang Spectoseopy}

Five milliliter sample aliquors were analyzed on detectors 4 and 5 in the INTEC gamma spectroscopy lab. These detectors are standard p-type coaxial germanium units. The samples were counted 0.5 hours on top of the detector.

The sample spectra were analyzed by the computer program resident on the lab computer. For this suite of samples fission and activation product isotopes were to be measured by ganma spectromerry. Instrumental background spectra were accumulated on these 
detector systems prior to use for these samples. After background subtraction, no detectable gamma emitters were found in these samples. 


\title{
SDG No\# W05199031RH
}

\author{
INTEC RADIOCHEMISTRY
}

\section{Raw Data Summary - Cover page, Forms I, I, III For:}

Am241, Np237, Tc99, Pu238 and Pu239/240 


\section{INTEC RADIOCHEMISTRY LABORATORY COVER PAGE}

\section{RADIOCHMMISTRY ANALYSES DATA PACKAGE}

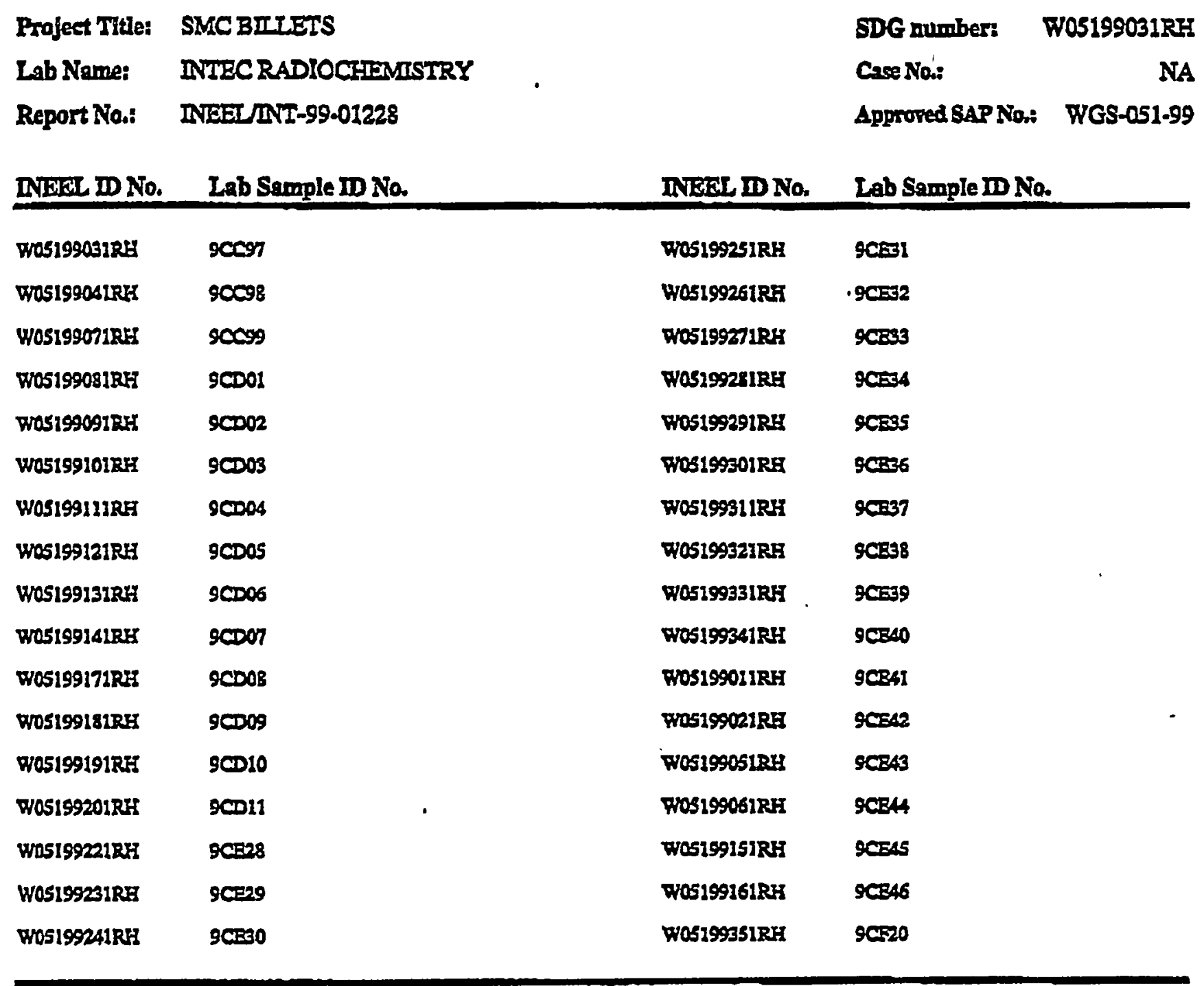

\section{Comments:}

Release of dets contalued in this data padisge bas been authorized by the laboratory manager or the manger's desiguess as verified by the folloping slguature:

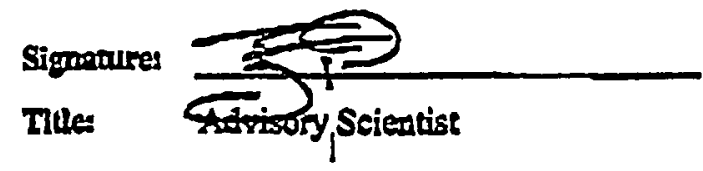

Name; Troy Tranter

Date: Tuesday, December 14, 1999 


\section{INTEC RADIOCHEMISTRY LABORATORY COVER PAGE}

\section{RADIOCHEMISTRY ANALYSES DATA PACKAGE}

\begin{tabular}{|c|c|c|c|c|}
\hline Project Title: & SMC BILLETS & & SDG number: & W0519903LRH \\
\hline Lab Name: & INIEC RADIOCFIMMISTRY & & Case Nas: & NA \\
\hline Report No.: & DNEEL/INT-99-01228 & & Approted SAP Na: & WGS.051-99 \\
\hline INEKL ID Na. & Lab Sample ID No. & INEEL ID No. & Lab Sample ID No. & \\
\hline WOS19936LR: & $90 \mathrm{Cr} 1$ & WOS199531RA & 9C241 & \\
\hline PO5799371RH & $9 \cos 22$ & WOSI99S4IRER & $9 \mathrm{CFA2}$ & \\
\hline WOS199381RE & $9 C F 23$ & WOS19S551RH & 907ss & \\
\hline W05199391RA & scres & WOSI9SSGIRH & 9CFA4 & \\
\hline WOS199401R: & 9CF25 & W0S199571RH & 9CR4S & \\
\hline WOS1994IIRE & 9CF26 & WOS19958LRH & gCF46 & \\
\hline WOS199421RR & 90527 & WOS199591RH & 9CFA & \\
\hline PDS199431RK & 9028 & WOS199601RH & 9CRA8 & \\
\hline WOS1994A1RF" & $9 \cos 2$ & WOSI9S5IIRH & 9CR49 & \\
\hline WOS199451RE: & $\operatorname{scrso}$ & WOS199621RE: & 9CF50 & \\
\hline WOSIS9461RK & $9 C F 31$ & WOS199211RH & 9 CPsi & \\
\hline WOS199491RR & $9 \operatorname{ser} 32$ & & & \\
\hline WO5199SOLRA & $9 C F 33$ & & & \\
\hline W0S19947IRH & 90534 & & & \\
\hline W05T99481RE & scross & & & \\
\hline HLS1995118RA & 90739 & & & \\
\hline WOS199521RE & $s c=40$ & & & \\
\hline
\end{tabular}

Comments:

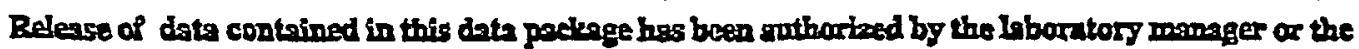
mangger's designes, 25 verified by the following signiture:

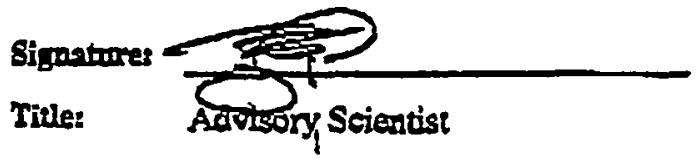

Name: Troy Tranter

Date: Tuesday, December 14, 1999 


\section{INTEC RADIOCHEMISTRY LABORATORY FORM I: Analysis Results}

Projeet Tilte: SMCBILLETS

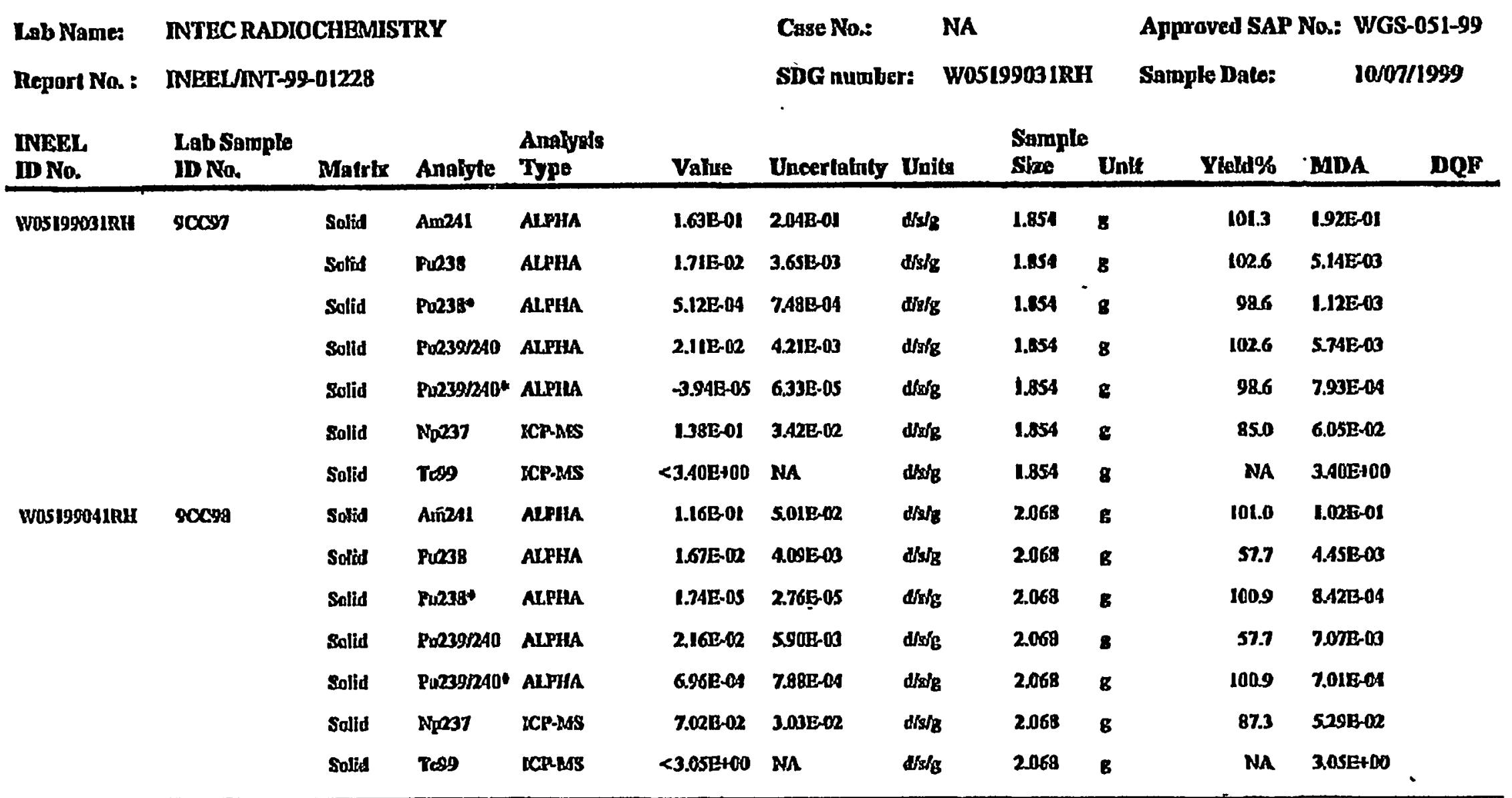


Project Tille: SMC BILLETS

Lab Name: DTEC RADIOCHEMISTRY

Report No.: INEEL/NTT-99-01228

\begin{tabular}{|c|c|c|c|c|c|c|c|c|c|c|c|c|}
\hline $\begin{array}{l}\text { INERTL } \\
\text { ID No. }\end{array}$ & $\begin{array}{l}\text { Lab Sample } \\
\text { ID No. }\end{array}$ & Matrix & Analyle & $\begin{array}{l}\text { Amalysify } \\
\text { Tgpe }\end{array}$ & Valuse & Uncertainty & Unlts & $\begin{array}{l}\text { Sample } \\
\text { Size }\end{array}$ & Unit & Yield\% & MDA & $\mathbf{D Q F}$ \\
\hline \multirow[t]{7}{*}{ WOS19907IRH } & 90099 & solid & Amz41 & ALPHA & $0.00 E+0 D$ & 6.80E-12 & $d / x / g$ & 2.459 & $\mathbf{g}$ & 40.8 & 2.725-01 & \\
\hline & & Solid & Pur38 & ALPHA & $4.418-02$ & 1.79E-0R & dhotg & 2.459 & B & 100.0 & $4.40 E-03$ & \\
\hline & & Solid & P.23380 & ALPHA & $0.00 \mathrm{E}+00$ & 3.358 .05 & $d s_{k}$ & 2459 & 8 & 100.2 & 1.34E-DA & \\
\hline & & Solld & PUP391210 & ALPHA & 9.8AE-02 & $3.27 \mathrm{E}-12$ & drste & 2.459 & $\mathbf{g}$ & 100.0 & $1.975-03$ & \\
\hline & & Solid & Prozs9n240* & ALPHA & S.50E-04 & $3.16 \mathrm{E}-\mathrm{A}$ & Als & 2.459 & E & 1002 & $5.245,04$ & \\
\hline & & solid & Np227 & ICPUAS & 9.40E-102 & 2900-02 & dors & 2.459 & 6 & 78.1 & 4.97E.02 & \\
\hline & & Solid & TeP9 & SCP-ASS & 3.225ENOD & L.ASET-DO & $d x_{B}$ & 2.459 & B & NA & 2.56E+00 & \\
\hline \multirow[t]{5}{*}{ WOSIS9OBIRH } & SCDOI & Solid & AmRAI & ALPHA & 6.A1B-02 & $8,6815-02$ & $d / S / S$ & 2.159 & E & 1028 & $9.79 \mathrm{~B}-12$ & \\
\hline & & Solid & Pu238 & ALPIKA & 7.578 .02 & $1.97 \mathrm{E}-10$ & $d x$ & 2.159 & B & 108.8 & $240 \mathrm{~B}-03$ & \\
\hline & & Solsid & Pu232/2A0 & ALPHA & 2.19E-02 & 3.78E.03 & dassi & 2.159 & B & 103.8 & $240 \mathrm{~B}-03$ & \\
\hline & & Solid & Np237 & ICPASS & $1.24 \mathrm{E}-01$ & T.15E-0R & $d d_{B}$ & 2.159 & B & 79.8 & $5.542-02$ & \\
\hline & & Solid & $T w 99$ & КCP-MS & $<2.92 \mathrm{E} 100$ & NA & $d / S / E$ & 2159 & B & NA & $29215+00$ & \\
\hline \multirow[t]{5}{*}{ WOS19909IRH } & gcDos & Solid & $\operatorname{Am} 241$ & ALPHA & 6.04E-02 & 8.9.8E-02 & wross & 1.856 & B & 104.9 & 2007E-01 & \\
\hline & & Solid & Pro3s & ALPHA & 1.19E- 02 & 4.26E-13 & diste & 1.856 & 8 & 62.2 & 9.66E-03 & \\
\hline & & Solid & PROX92AD & ALPHA & 9.03E- -19 & $1.5215-02$ & $d s / B$ & 1.856 & 8 & 62.2 & 1.478.02 & \\
\hline & & solid & $\mathrm{Np237}$ & ICRas & A.SBEA & 3.506 .02 & orssig & 1.856 & B & 79.2 & 6.ADE-10 & \\
\hline & & Solld & $T e s 9$ & ICP-MS & $<339 E+00$ & NA & $d / w_{B}$ & 1.856 & 5 & NA & $3.39 \mathrm{E}+00$ & \\
\hline WOSIS9LOLRU & SCDN3 & Solid & Am2241 & ALPHA & $1.06 \mathrm{E}-01$ & 1.34E-01 & d/W/E & 2.336 & 8 & 106.9 & 1.278-0I & \\
\hline
\end{tabular}

Wodinerday, December 15, 1999

Cane No: NA Approved SAP Na: WGS-051-99

SDG number: Wos19903IRH Sample Date: 10/07/1999

* Fusion prep perfarmed for Qtese analynea. 
Project Tille: SMCBILLETS

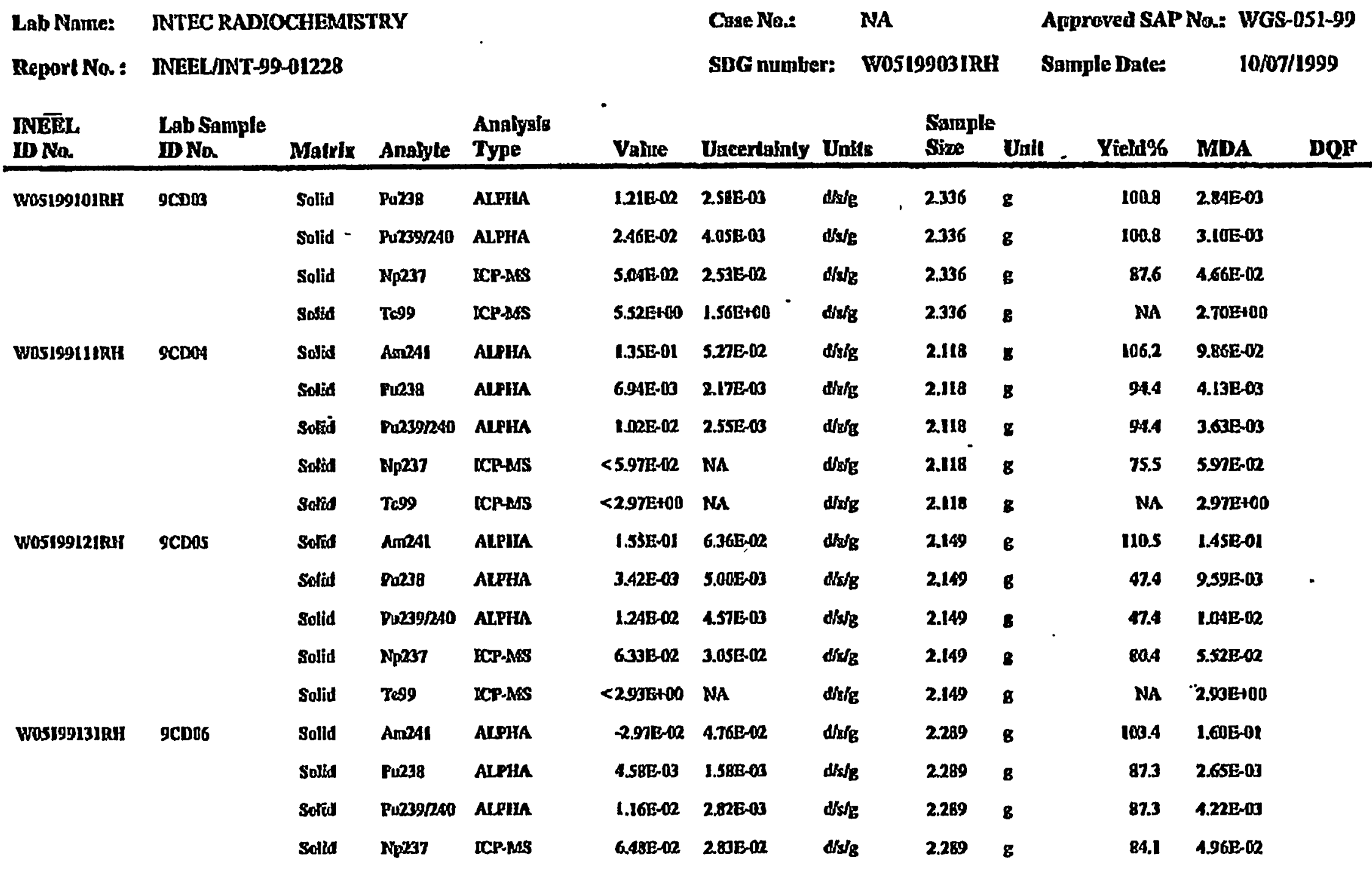


Project Title: SMC BILLETS

\begin{tabular}{|c|c|c|c|c|c|c|c|c|c|c|c|c|}
\hline \multirow{3}{*}{$\begin{array}{l}\text { Lab Name: } \\
\text { Report No. } \\
\text { INEE } \\
\text { ID Na. }\end{array}$} & \multirow{2}{*}{\multicolumn{5}{|c|}{$\begin{array}{l}\text { INTEC RADIOCHEMISTRY } \\
\text { INEIELINT-99.01228 }\end{array}$}} & \multirow{2}{*}{\multicolumn{2}{|c|}{$\begin{array}{l}\text { Case No.: } \\
\text { SDG number: }\end{array}$}} & \multirow{2}{*}{$\begin{array}{l}\text { NA } \\
\text { WOSI9903IRH }\end{array}$} & \multirow{2}{*}{\multicolumn{2}{|c|}{$\begin{array}{l}\text { Approved SAP N } \\
\text { Sample Date: }\end{array}$}} & \multirow{2}{*}{\multicolumn{2}{|c|}{$\begin{array}{l}\text { T0.: WGS-0S1-99 } \\
\text { 10/07/1999 }\end{array}$}} \\
\hline & & & & & & & & & & & & \\
\hline & $\begin{array}{l}\text { Lab Sample } \\
\text { ID No. }\end{array}$ & Matrix & Analyle & $\begin{array}{l}\text { Analysis } \\
\text { Type }\end{array}$ & Value & Uncertalnty & Units & $\begin{array}{l}\text { Sample } \\
\text { Size }\end{array}$ & Unit & Yicld\% & MDA & DQF \\
\hline WOSI9913IRH & SCDOG & Solid & Ta9 & ICPASS & $<2.756+00$ & NA & $d x / g$ & 2.289 & E & NA & $2.75 E+00$ & \\
\hline \multirow[t]{5}{*}{ WOS19914IRH } & SCDOI & Solid & Am2N1 & ALPHA & $8.80 E-02$ & 1.09E-01 & dhafg & 20070 & B & 100.7 & $9.07 \mathrm{~B}-02$ & \\
\hline & & Solid & Pu238 & ALPHA & $1.266-00$ & 1.91E-03 & $w_{s} v_{g}$ & 2.070 & 8 & 78.2 & $7.49 \mathrm{E}-03$ & \\
\hline & & Solid & Puz3912A0 & ALPHA . & $-4.30 \mathrm{E}-02$ & $7.11 \mathrm{E}-02$ & drof & 2.070 & G & 78.2 & $1.30 \mathrm{~B}-02$ & \\
\hline & & Solich & $N_{7} 237$ & ICPAMS & $<5.50 \mathrm{E}-02$ & MA & $d b_{B} / B$ & 2.070 & B & 83.8 & S.50E-02 & \\
\hline & & Solid & TeS9 & ICP-ACS & $<3.04 E+00$ & NA & $d / 1 / B$ & 2070 & 8 & NA & $3.0485+00$ & \\
\hline \multirow[t]{5}{*}{ WOS199171RK } & 9CDng & Solid & Am241 & ALPHA & $8.74 \mathrm{E}-02$ & $1.205-01$ & $d / / g$ & 2.021 & 8 & 104.1 & I.41E.0I & \\
\hline & & Solld & Pues: & ALPHA & 9.73E-03 & 2.89E-03 & distis & 2.021 & B & 86.7 & $5.6 A B-03$ & \\
\hline & & Sollid & Plor39:240 & ALPHA & 1.37E- -2 & $3.15 \mathrm{E}-03$ & dakg & 2.021 & E & 86.7 & $3.79 \mathrm{R}-03$ & \\
\hline & & Sobid & Noxy7 & ICRMS & $<5.68 \mathrm{E}-02$ & $\mathbf{N A}$ & $d / s / g$ & 2,021 & 8 & 83.0 & $5.68 \mathrm{E}-02$ & \\
\hline & & Solid & $\operatorname{Tes} 9$ & ICP-MS & $<3.12 \mathrm{E}+00$ & NA & $d / / 2 / B$ & 2.021 & E & NA & $3.12 \mathrm{E}+00$ & \\
\hline \multirow[t]{5}{*}{ WOSI9918IRH } & $9 C D 09$ & Solld & Am241 & ALPIIA & S.AIE.02 & 7.J8E-02 & d/sig & 1.962 & g & 100.5 & 8.57E-02 & \\
\hline & & Solid & Pu238 & ALPHA & $5.11 \mathrm{E}-00$ & $6.91 \mathrm{E}-00$ & $d x d B$ & 1.962 & E & 72.6 & 7.83E-03 & \\
\hline & & Solid & PL239RAD & ALPHA & 9.5SE-03 & 1.18E-02 & $d / s / g$ & 1.962 & E & 72.6 & $1.09 \mathrm{E}-02$ & \\
\hline & & Solid & Np237 & SCP-ASS & $<5.86 \mathrm{E}-02$ & NA & dhatg & 1962 & B & 83.0 & $5.86 \mathrm{E}, 0 R$ & \\
\hline & & Salid & $\operatorname{Tos} 9$ & ICP.MSS & $<3.21 \mathrm{E}+00$ & NA & $d d_{B}$ & 1.952 & $\varepsilon$ & $\mathbf{M A}$ & J.21E+WO & \\
\hline \multirow[t]{2}{*}{ WOS199191RH } & 9CD10 & Soltid & $A m 241$ & AlPHA & $0.00 \mathrm{E}+00$ & $5.2005-12$ & $d s / g$ & 2.057 & B & 102.0 & 2.07E-01 & \\
\hline & & Solisid & Pu238 & ALPHA & $4.20 \mathrm{E}-03$ & A.59B-OB & $d x d g$ & 2057 & B & 90.7 & $4.225-03$ & \\
\hline
\end{tabular}


Projoct Tille: SMCBILLETS

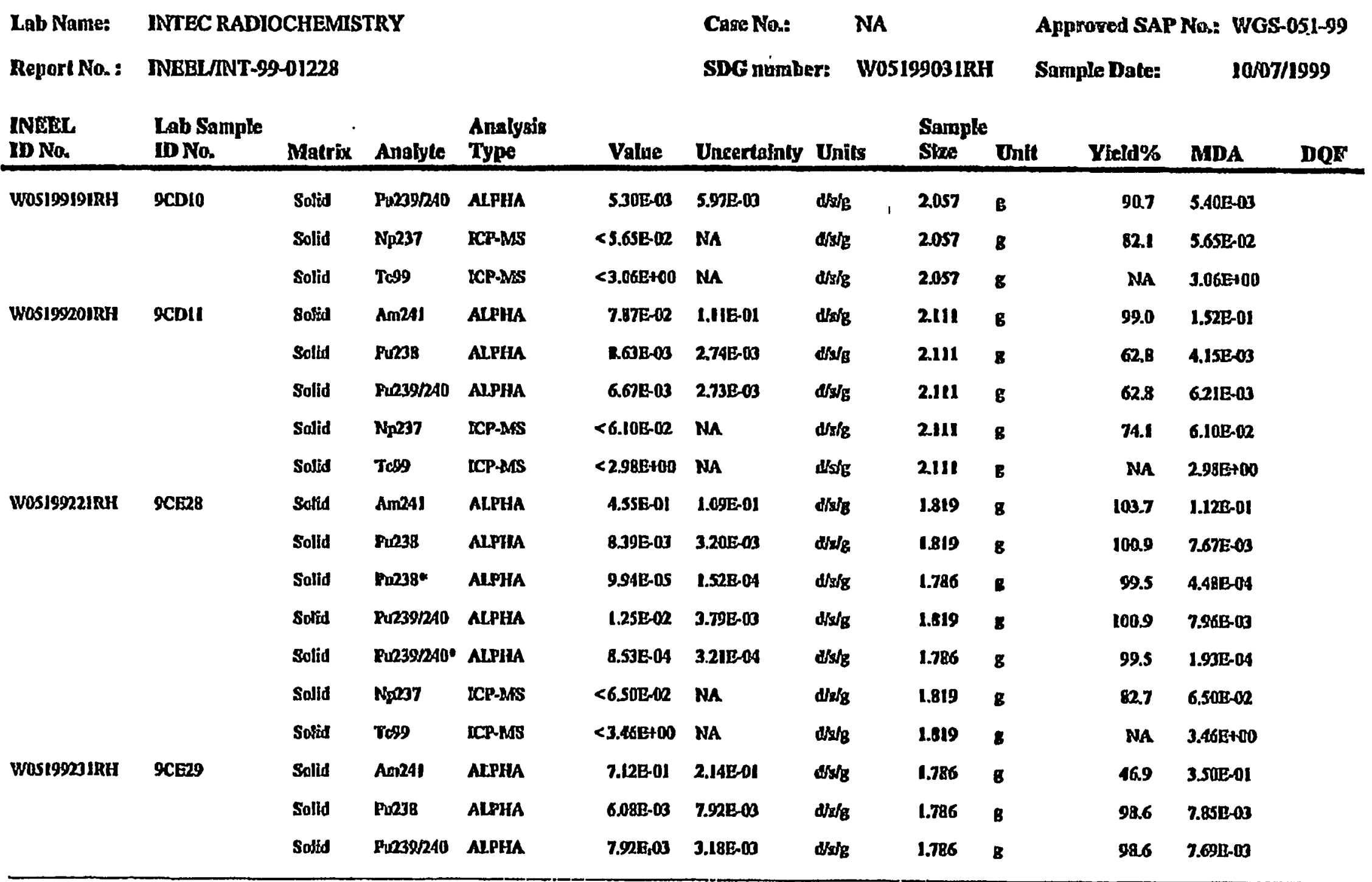

Wedressiay, Decembor 15, 1999 
Project Tille: SMC BILLETS

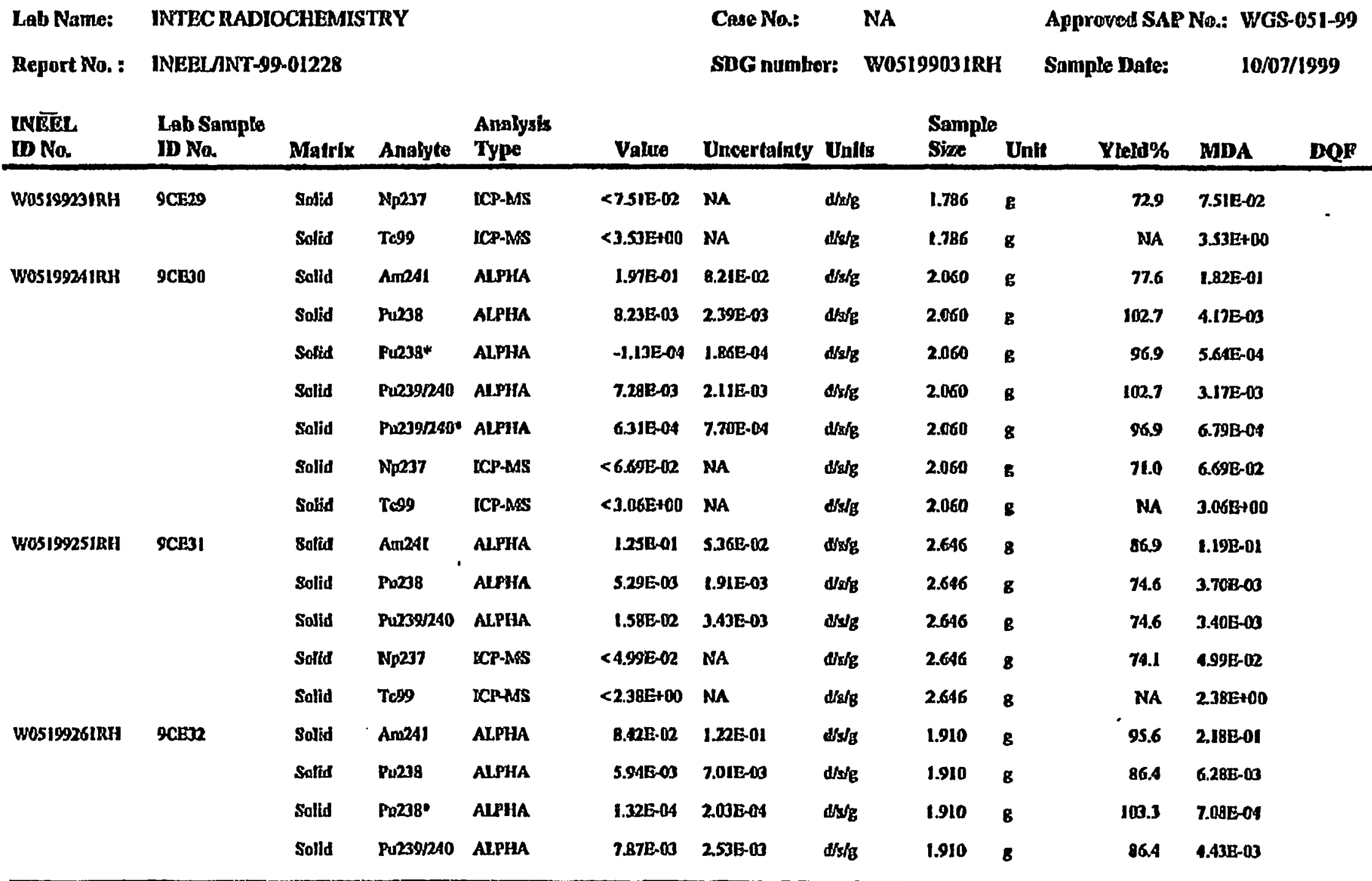

Wednesday, December 15, 1999 * Fusson prep performed for these gnalybes. 


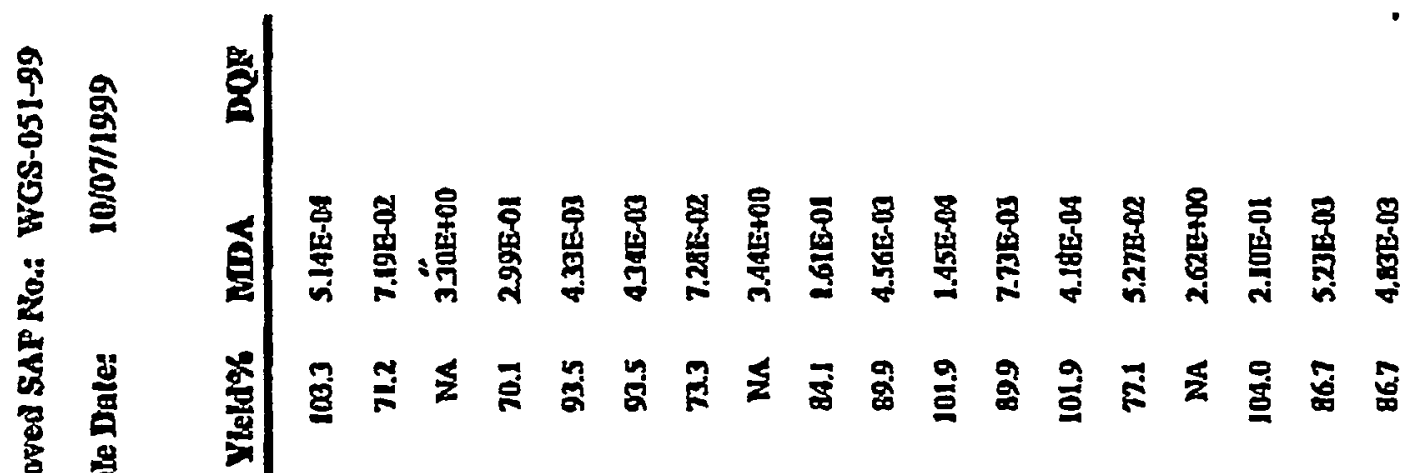

总总

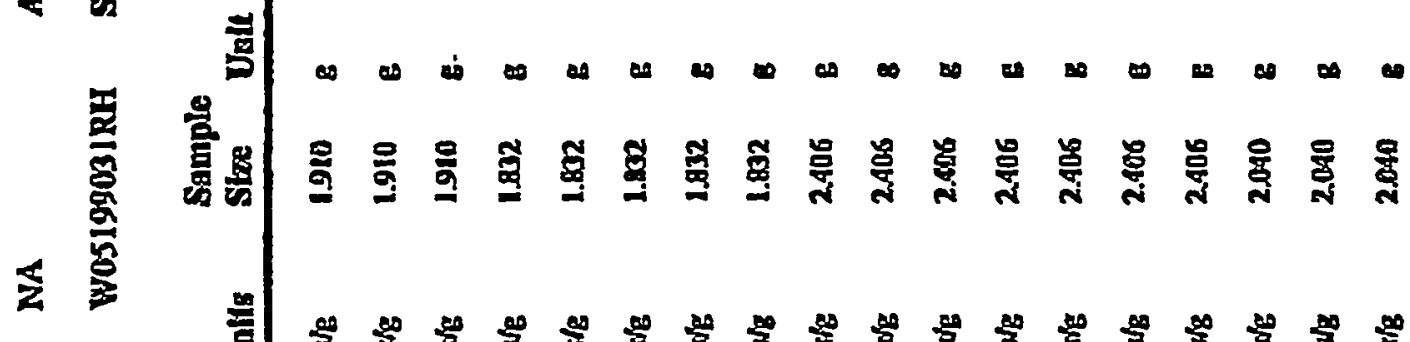

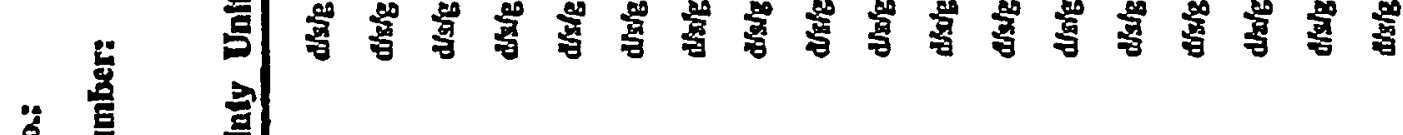
远豆 켤

总葛

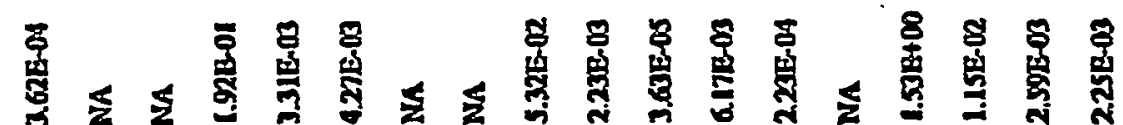
兽

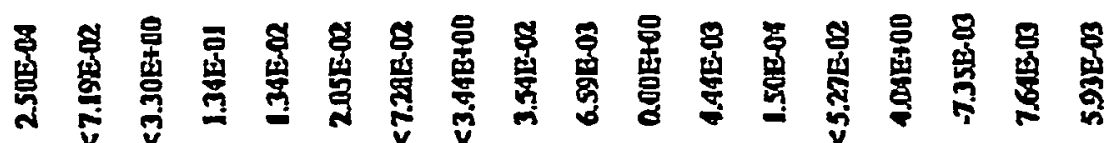

훌

遂

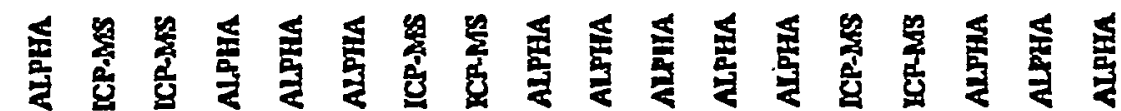

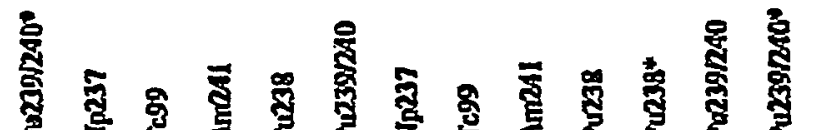

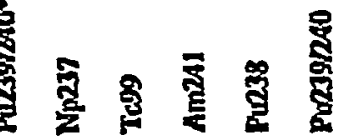

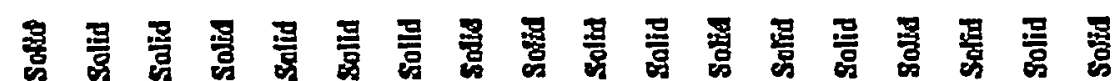

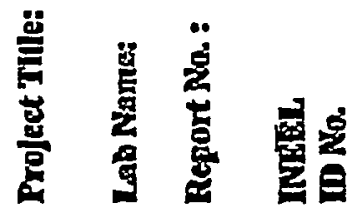

臨

畓

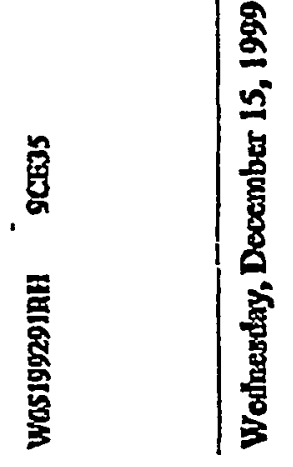


Projeet Titlo: SMC BILLETS

LAB NamE: INTPC RADIOCHEMISTRY

Cuse No.: NA Approved SAP No.: WGS-051-99

Report No.: INEELINT-ge-01228

SDG mumber: W0519903 IRH Sample Date: 10/07/1999

\begin{tabular}{|c|c|c|c|c|c|c|c|c|c|c|c|c|}
\hline $\begin{array}{l}\text { INEAL } \\
\text { ID No. }\end{array}$ & $\begin{array}{l}\text { Lab Sample } \\
\text { ID No. }\end{array}$ & Matrix & Analyte & $\begin{array}{l}\text { Analyals } \\
\text { Type }\end{array}$ & Valure & Incerfalnty & Unils & $\begin{array}{l}\text { Sample } \\
\text { Shere }\end{array}$ & Unit & Yleld\% & MDA & DQR \\
\hline \multirow[t]{2}{*}{ WWS19929IRH } & sceas & Solida & Np231 & ICP-MSS & $<6.56 \mathrm{E}-02$ & NA & dowg & 2.040 & 8 & 73.1 & $6.56 \mathrm{E}-02$ & \\
\hline & & Solid & ToS9 & ICPABS & $<3.098+00$ & NA & desig & 2.040 & $g$ & NA & 3.09E100 & \\
\hline \multirow[t]{7}{*}{ WOS 19930IRH } & $9 C B 36$ & Solid & Am241 & ALPHA & $-6.46 \mathrm{E} \cdot 02$ & 1.048 .01 & $d / 2 / g$ & 2.223 & B & 75.5 & $3.42 \mathrm{E}-0 \mathrm{l}$ & \\
\hline & & Solld & Pu238 & ALPHA & 8.6513-03 & $2.86 \mathrm{~B}-03$ & $d s y_{g}$ & 2.223 & $\mathbf{8}$ & 846 & $5.912-00$ & \\
\hline & & Solid & Paza80 & ALPYA & $-1.74 \mathrm{E}-04$ & $2880-04$ & $d / d x$ & 2.223 & $\mathbf{g}$ & 100.6 & 6.26E-04 & \\
\hline & & Solid & Pux39/240 & ALPHA & $1.50 \mathrm{E}-02$ & 3.85E-03 & $d / s / s$ & 2.223 & E & 84.6 & $6.63 \mathrm{~B}-03$ & \\
\hline & & Solid & P.230/240" & ALPHA & $-6.40 \mathrm{E}-04$ & 1.09200 & $d x_{k}$ & 2.223 & 8 & 100.6 & 1.312-03 & \\
\hline & & Solid & Np237 & KCP-MPS & $<5,32 \mathrm{E}-02$ & NA & $d: / g$ & 2.223 & 8 & 82.7 & $5.3216-02$ & \\
\hline & & Solid & $\operatorname{Tc} 99$ & ICP-MS & $3.66 \mathrm{E}+00$ & 1.61E+00 & $d / 2 / g$ & 2223 & E & $\mathbf{N A}$ & $2.83 E+00$ & \\
\hline \multirow[t]{5}{*}{ WOSI993LIAFT } & 9Cej7 & Solid & Am24t & ALPHA & $-5.78 \mathrm{E}-02$ & $9.322 E-02$ & $d / x f_{E}$ & 1.924 & B & 87.7 & $2.64 \mathrm{~B}-01$ & \\
\hline & & Solid & Pu238 & ALPFA & $622 \mathrm{E}-13$ & 8. $108-00$ & dats & 1.924 & $\mathbf{B}$ & 91.2 & 8.05E-03 & \\
\hline & & Solid & Pue39/240 & ALPHA & $6.801-03$ & 8.56E: 03 & $d / s / g$ & 1.924 & $\mathbf{E}$ & 912 & 7.89E-03 & \\
\hline & & Solid & Np237 & $\mathrm{KCP}-\mathrm{MSS}$ & $<6.10 \mathrm{E}-02$ & NA & 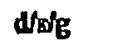 & 1.924 & E & 833 & 6.10E-0R & \\
\hline & & Solid & $\operatorname{Tan} 9$ & DCP-MS & $<3.27 \mathrm{E}+00$ & NA & $d / s / s$ & 1.924 & 8 & NA & $3.2 J E+00$ & \\
\hline \multirow[t]{4}{*}{ WOSL9932LRY } & 9CE38 & Solid & Am241 & AIPHA & I.IAB-DI & $1.42 \mathrm{E}-\mathrm{BL}$ & $d / s=g$ & 1998 & $\mathbf{B}$ & 102.5 & $1.32 \mathrm{E}-01$ & \\
\hline & & Solid & Puesa & ALPHA & $1.96 \mathrm{E}-02$ & 4.23E-03 & $d+d / g$ & 1.998 & E & 79.8 & 4.22E-DS & \\
\hline & & Solid & $\mathrm{P} 0238^{\circ}$ & ALALA & 6.40E.05 & 1.012-04 & $d / S J_{B}$ & 1.998 & E & 1062 & I.OTE-Q3 & \\
\hline & & Solid & Pu239/240 & ALPLXA & I.7SER-02 & A.03E-103 & $U_{k} / \mathrm{B}$ & $\$ .998$ & 8 & 79.8 & $4.95 \mathrm{E}-00$ & \\
\hline
\end{tabular}

Wedinesday, December 15, 1999

- Fusion prep performod for these analyses. 
Project Tulte: SMC BILLETS

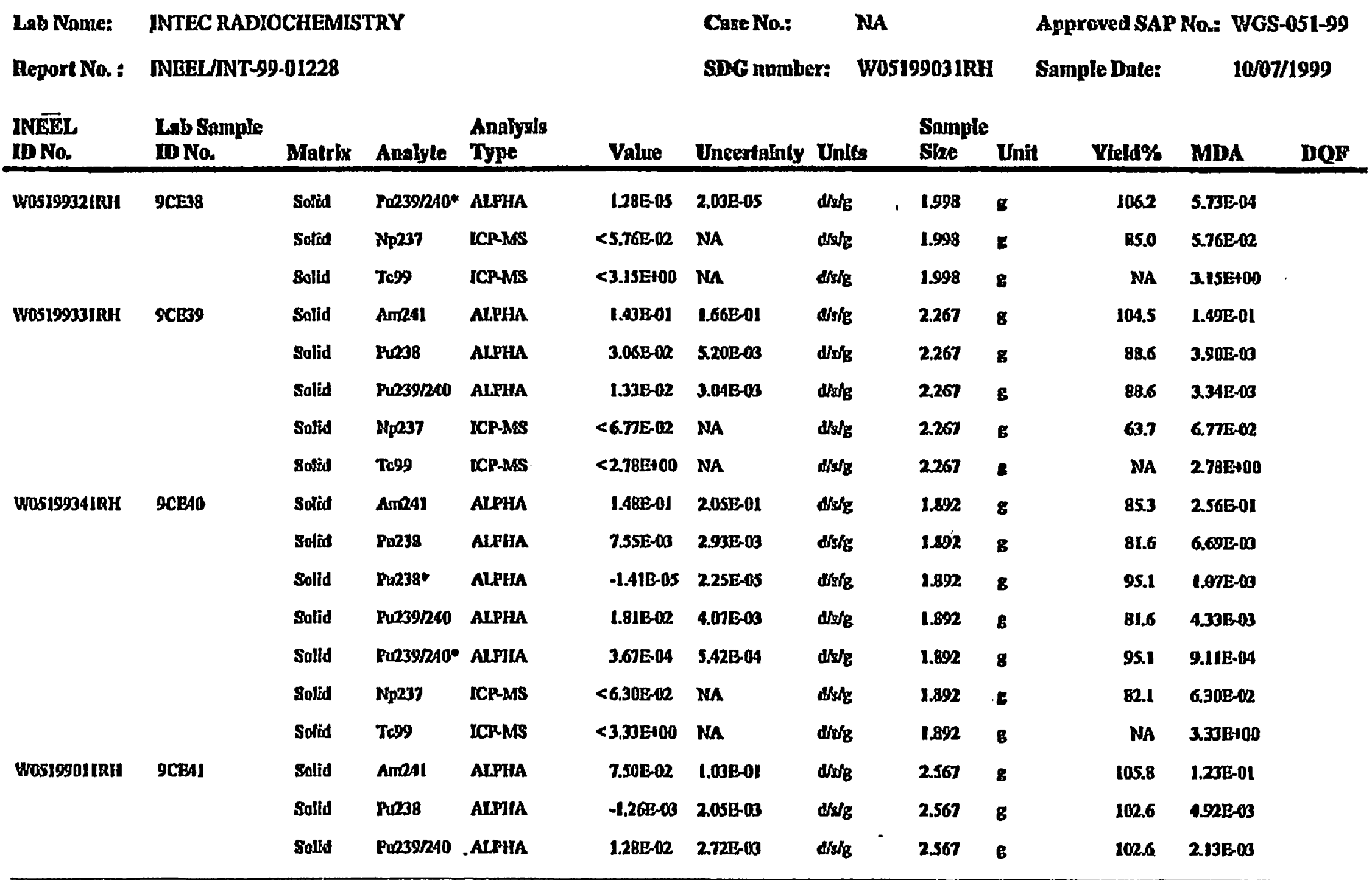

Wednesday, December 15, 1999 "Fusion prep performed for These analyses. 
Projeet Title: SMC BILLETS

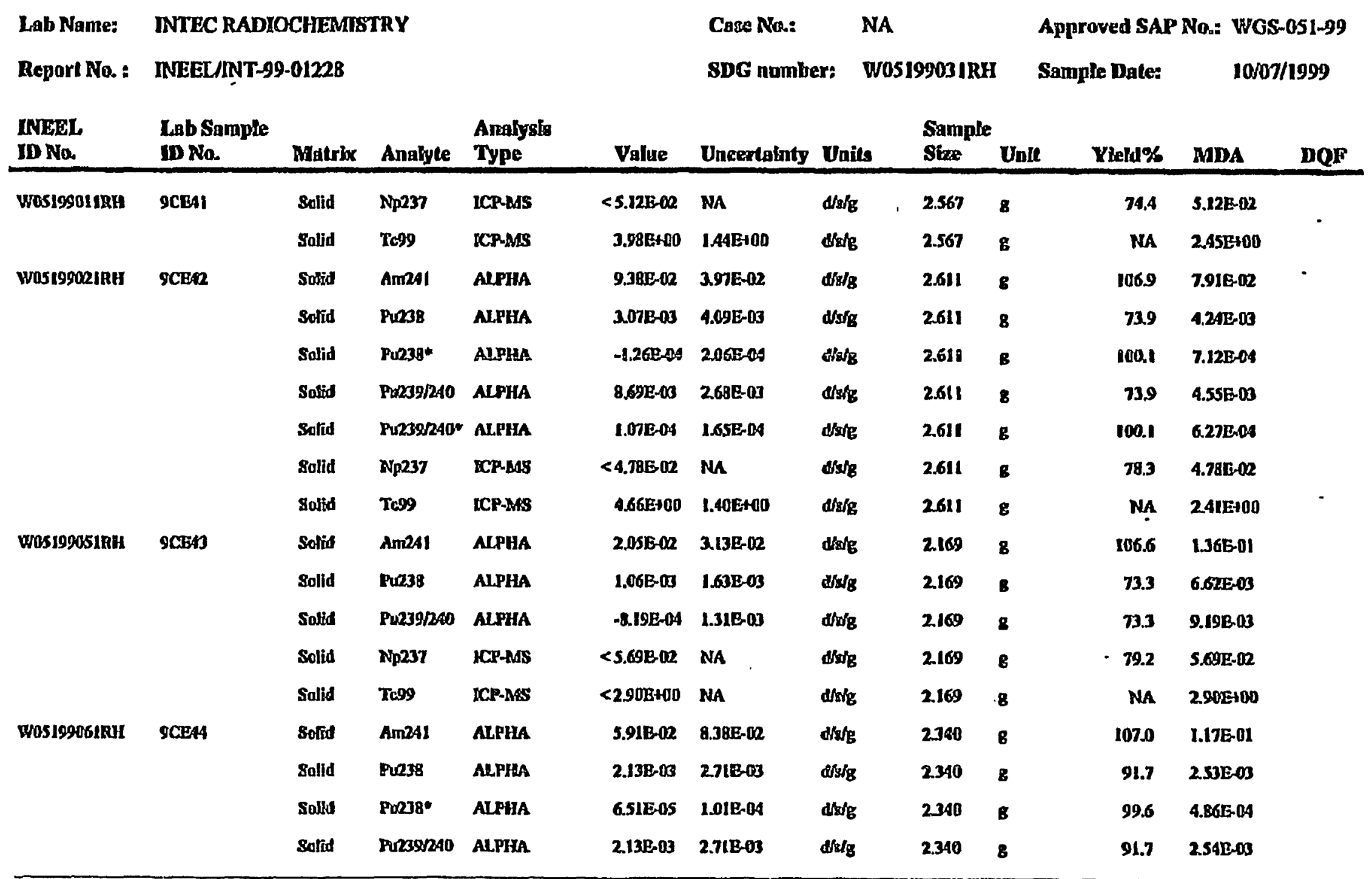


Profect Tille: SMC BILLETS

\begin{tabular}{|c|c|c|c|c|c|c|c|c|c|c|c|c|}
\hline \multirow{2}{*}{$\begin{array}{l}\text { Lab Name: } \\
\text { Report No. } \\
\text { INEEL } \\
\text { ID No. }\end{array}$} & \multicolumn{5}{|c|}{$\begin{array}{l}\text { INTEC RADIOCHEMISTRY } \\
\text { INEEUNTT-99-01228 }\end{array}$} & \multicolumn{2}{|c|}{$\begin{array}{l}\text { Care No: } \\
\text { SoG number: }\end{array}$} & $\begin{array}{l}\text { NA } \\
\text { W05199031RH }\end{array}$ & \multicolumn{4}{|c|}{$\begin{array}{l}\text { Approved SAP Na: WGS-051-99 } \\
\text { Sample Date: } \quad \text { 10/07/1999. }\end{array}$} \\
\hline & $\begin{array}{l}\text { Lab Sample } \\
\text { ID No. }\end{array}$ & Malrix & Analyle & $\begin{array}{l}\text { Analysis } \\
\text { Type }\end{array}$ & Value & Uncertainty & Unils & $\begin{array}{l}\text { Sample } \\
\text { Strue }\end{array}$ & Unit & Yield\% & MDA & DQF \\
\hline \multirow[t]{3}{*}{ WosisgosiRH } & SCEAA & Salid & P0239240" & ALPHA & $9.56 \mathrm{~B}-0 \mathrm{~A}$ & $3.41 \mathrm{E}-04$ & $d s_{c}$ & 2.340 & 8 & 99.6 & 5.39E-04 & \\
\hline & & Solid & Np237 & ICP-MS & <S.BSE-02 & MA & $d s / s$ & 2340 & 8 & 21.4 & $5.85 \mathrm{E}-02$ & \\
\hline & & Soltd & $\operatorname{ros} 9$ & ICP-MS & $<2.69 E+00$ & NA. & $d / d_{g}$ & 2.340 & E & NA & $2.698+00$ & \\
\hline \multirow[t]{5}{*}{ WASI9915IRH } & PCEAS & Solid & Am241 & ALPAA & $-1.685-02$ & $266 \mathrm{E}-102$ & Wys & 2.213 & B & 105.4 & 2.19E-01 & \\
\hline & & Solind & PuR238 & ALPILA & $3.95 \mathrm{E}-03$ & $1.49 \mathrm{E}-0 \mathrm{~B}$ & $d / d B$ & 2213 & 8 & 94.7 & $2.58 B-00$ & \\
\hline & & Spotide & PW239R40 & ALPHA & $1.59 \mathrm{E}-02$ & $3.39 \mathrm{E}-03$ & $d / s_{0}$ & 2213 & 8 & 94.7 & 2.98E-03 & \\
\hline & & Solids & Np237 & ICPMSS & $<6.05 E-12$ & $\mathbf{M A}$ & $d s / B$ & 2.213 & 8 & 73.1 & 6.05E-02 & \\
\hline & & Solld & $\operatorname{Tes} \theta$ & ICP-MSS & $3.85 E+00$ & 1.64EH00 & $\mathrm{d} / \mathrm{s} / \mathrm{B}$ & 2.213 & B & NA & $2.85 \mathrm{E}+00$ & \\
\hline \multirow[t]{7}{*}{ WOS199161RII } & SCEA6 & Solid & $A m 2 A 1$ & ALPLA & Q48de-02 & $1.22 \mathrm{E}-01$ & $d y g$ & 1.934 & $\mathbf{B}$ & to5.5 & 1.97E-01 & \\
\hline & & Solid & Pues3 & ALPHA & 5.198 .03 & $6.588-0]$ & thos & 1.934 & 8 & 83.8 & 6.14E-03 & \\
\hline & & Solid & Pu238: & ALPHA & $-3.93 \mathrm{E}-0 \mathrm{~S}$ & 6.33E-05 & distg & 1.934 & 8 & 99.4 & 4.23E-OS & \\
\hline & & Soltad & Pa209/240 & ALPHA & $1.40 E-02$ & $3.80 \mathrm{E}-03$ & $d / B / B$ & 1.934 & $B$ & 83.6 & S.13E-0B & \\
\hline & & Solid & Pu232/240" & ALPHA & $2.23 \mathrm{E}-04$ & 3.36E-04 & $d / / / B$ & 1.934 & B & 99.4 & 7.56E-04 & \\
\hline & & Solid & Np237 & SCP-ASS & $<G .17 E-0 R$ & NA & $d y$ & 1.924 & C & 81.9 & 6.17E-102 & \\
\hline & & Solid & TC9 & ICP-MS & $8.73 E+100$ & $1.75 E+00$ & $d s / g$ & 1.934 & 8 & $\mathbf{N A}$ & $3.26 \mathrm{E}+100$ & \\
\hline \multirow[t]{3}{*}{ WOS19935IRH } & SCFO & Solid & $A m 241$ & ALPHA & $7.24 \mathrm{E}-02$ & $1.03 \mathrm{E}, 01$ & $d s / g$ & 2.008 & 8 & 800.9 & I.43E-01 & \\
\hline & & Sossd & Puezs & ALPIIA & $2.65 E-13$ & $3.75 E-13$ & $d / d t_{B}$ & 2.006 & E & 93.3 & S.1SE-03 & \\
\hline & & Sollid & Pu239/240 & ALPHA & 2.15E-02 & A.AKE-13 & $d y_{6}$ & 2.006 & E & 93.3 & $4.38 \mathrm{E}-03$ & \\
\hline
\end{tabular}

Wednesday, December 15, 1999

- Fusion prep performed for these analyses. 
Profecl TIlle: SMC BILLETS

\begin{tabular}{|c|c|c|c|c|c|c|c|c|c|c|c|c|}
\hline \multirow{3}{*}{ 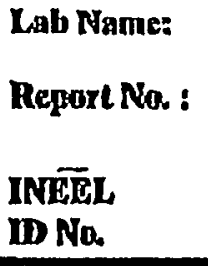 } & \multirow{2}{*}{\multicolumn{5}{|c|}{$\begin{array}{l}\text { INTEC RADKOCHEMISTRY } \\
\text { INEEL/NTT-99-01228 }\end{array}$}} & \multirow{2}{*}{\multicolumn{2}{|c|}{$\begin{array}{l}\text { Case Na: } \\
\text { SDG number: }\end{array}$}} & \multirow{2}{*}{$\begin{array}{l}\text { NA } \\
\text { W0S19903IRH }\end{array}$} & \multicolumn{4}{|c|}{ Approved SAP Na.: WGS-051-99 } \\
\hline & & & & & & & & & \multicolumn{2}{|c|}{ Sample Date: } & \multicolumn{2}{|c|}{ 10/07/1999 } \\
\hline & $\begin{array}{l}\text { Lab Sample } \\
\text { ID No. }\end{array}$ & Mairix & Analyte & $\begin{array}{l}\text { Analysia } \\
\text { Type }\end{array}$ & Valure & Uncerlointy & Unils & $\begin{array}{l}\text { Sample } \\
\text { Strexe }\end{array}$ & Unit & Yfelato & MDA & DQF \\
\hline \multirow[t]{2}{*}{ MOSI9935IRH } & SCFzO & Solid & Np237 & ICRAAS & $<5.79 E .02$ & NA & dralg & 2.006 & 8 & 84.2 & $5.79 E-02$ & \\
\hline & & Solid & Tc99 & ICPASS & $8.09 E+100$ & $1.67 \mathrm{E}+00$ & dudg & 2.006 & B & NA & $3.14 E+100$ & \\
\hline \multirow[t]{5}{*}{ WOS1S936IRH } & 9CF21 & Solid & Am2At & ALPEA & $1.22 \mathrm{E}-01$ & 1.43E-01 & $d / 2 / B$ & 2.186 & E & 104.5 & 1.28E-01 & \\
\hline & & Solid & PQR38 & ALPHA & 3.18E-03 & 3.695 .03 & $d / 2 / 8$ & 2.186 & 8 & 87.4 & $3.28 E-19$ & \\
\hline & & Solid & $P 02391240$ & ALPHA & $7.82 \mathrm{E.03}$ & 2.32E-03 & ât & 2.186 & B & 87.4 & 3.296-03 & \\
\hline & & Solid & Np237 & DCP-MS & 6.17E-02 & $2.67 \mathrm{E}-02$ & $d x$ & 2.186 & B & 95.9 & 4.66E-02 & \\
\hline & & solid & $\operatorname{Tc} 99$ & ICPMS & $3.50 E+00$ & $1.62 E+00$ & $d / A_{B}$ & 2.186 & E & NA & $288 \mathrm{E}+00$ & \\
\hline \multirow[t]{5}{*}{ WOSI9937JRH } & 9CF22 & Solid & Am241 & ALPEA & 7.15E-02 & 1.13B-01 & d/sSB & 2.057 & e & 992 & $1.82 \mathrm{E}-01$ & \\
\hline & & Solid & Pu238 & ALPHA & 1.93E-03 & 281E-03 & $d / s / g$ & 2.057 & E & 18.6 & 4.67E-03 & \\
\hline & & Solld & Fu2391240 & AlPFA & $1.52 \mathrm{E}-02$ & 3.57E-03 & $d / s / g$ & 2.057 & $\varepsilon$ & 88.6 & $4.23 \mathrm{~B} \cdot 03$ & \\
\hline & & Solisd & $\operatorname{Ma237}$ & ICP-ASS & $<5.5518-02$ & NA & datg & 2.057 & 8 & 85.7 & $5.55 E-02$ & \\
\hline & & Solid & Tes9 & ICPMS & $4.57 E+00$ & $1.78 E+00$ & dadg & 2.057 & $\mathbf{8}$ & NA & $3.06 E+00$ & \\
\hline \multirow[t]{5}{*}{ WOS19938IRH } & 9CF23 & Solid & Am241 & ALPHA & $5.73 \mathrm{E}-02$ & $8.50 \mathrm{E}-02$ & dhsog & 1.767 & $\mathbf{B}$ & 104.2 & $1.98 \mathrm{E}-01$ & \\
\hline & & Solid & Pu238 & ALPHA & 4.55E-03 & 2.06E-03 & Hy/g & 1.767 & B & 22.0 & 4.25E- 03 & \\
\hline & & Solid & Pu239/240 & ALPUA & $1.59 \mathrm{~B}-02$ & 4.13E- -03 & d/sos & 1.767 & $\mathbf{B}$ & 72.0 & $4.92 \mathrm{BB}-03$ & \\
\hline & & Solitid & Np23? & ICPASS & $<738 \mathrm{E}-02$ & $N A$ & $d / d / B$ & 1.267 & $\mathbf{B}$ & 75.0 & $7.38 \mathrm{E}-02$ & \\
\hline & & Solid & Tथ9 & ICPANS & $<3.56 \mathrm{E}+00$ & NA & $d / 2 / g$ & 1.767 & $\mathbf{B}$ & NA & $3.568+00$ & \\
\hline WOS199391RH & 9CFZA & Solid & Am24I & ALPHA & 9.31E-02 & 1.37E-01 & $d / 2 / g$ & 2.074 & E & 108.6 & 275E-DI & \\
\hline
\end{tabular}

- Fusion prep performed for theso analyses. 


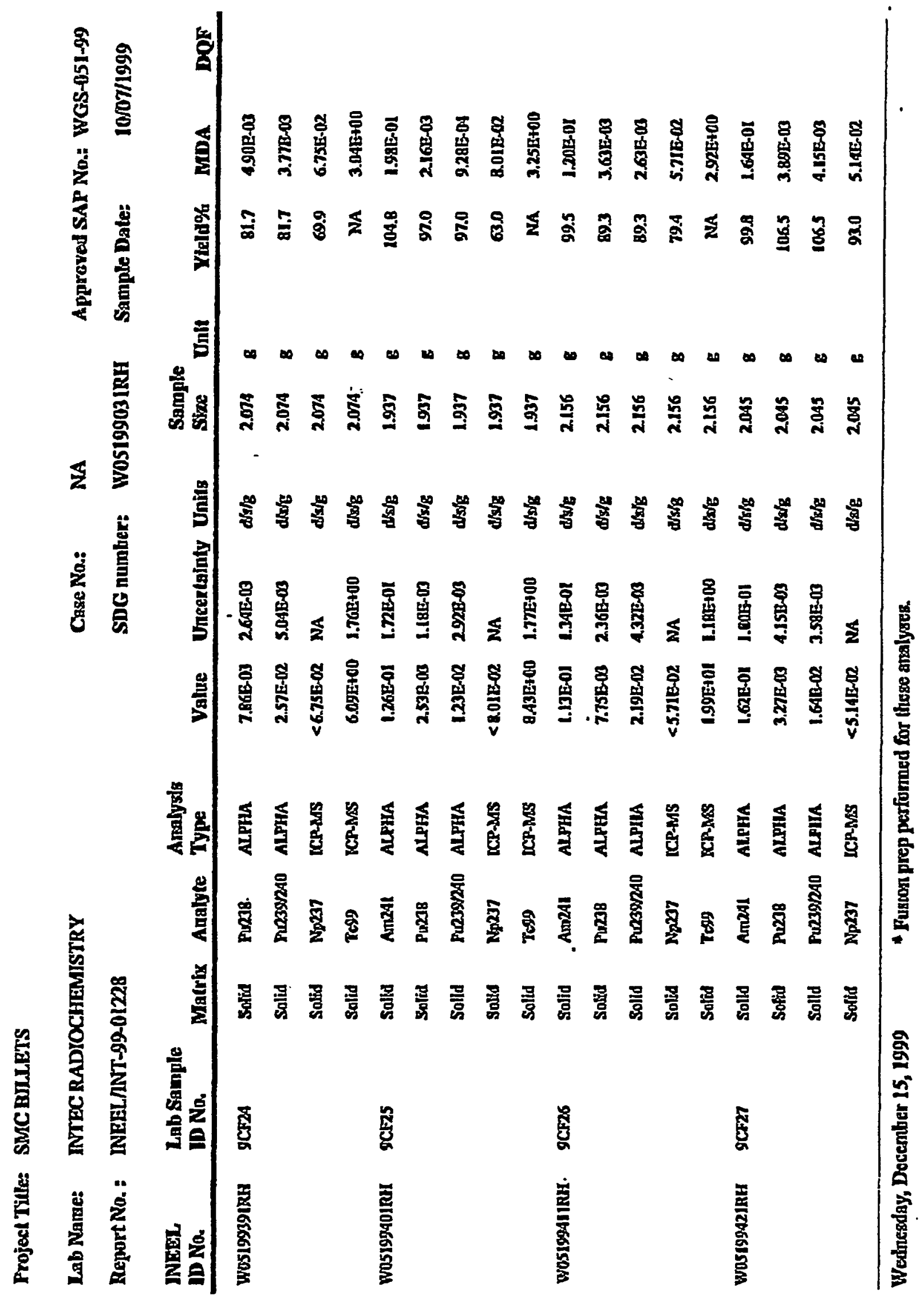




\section{Projeet TUle: SMCBILLETS}

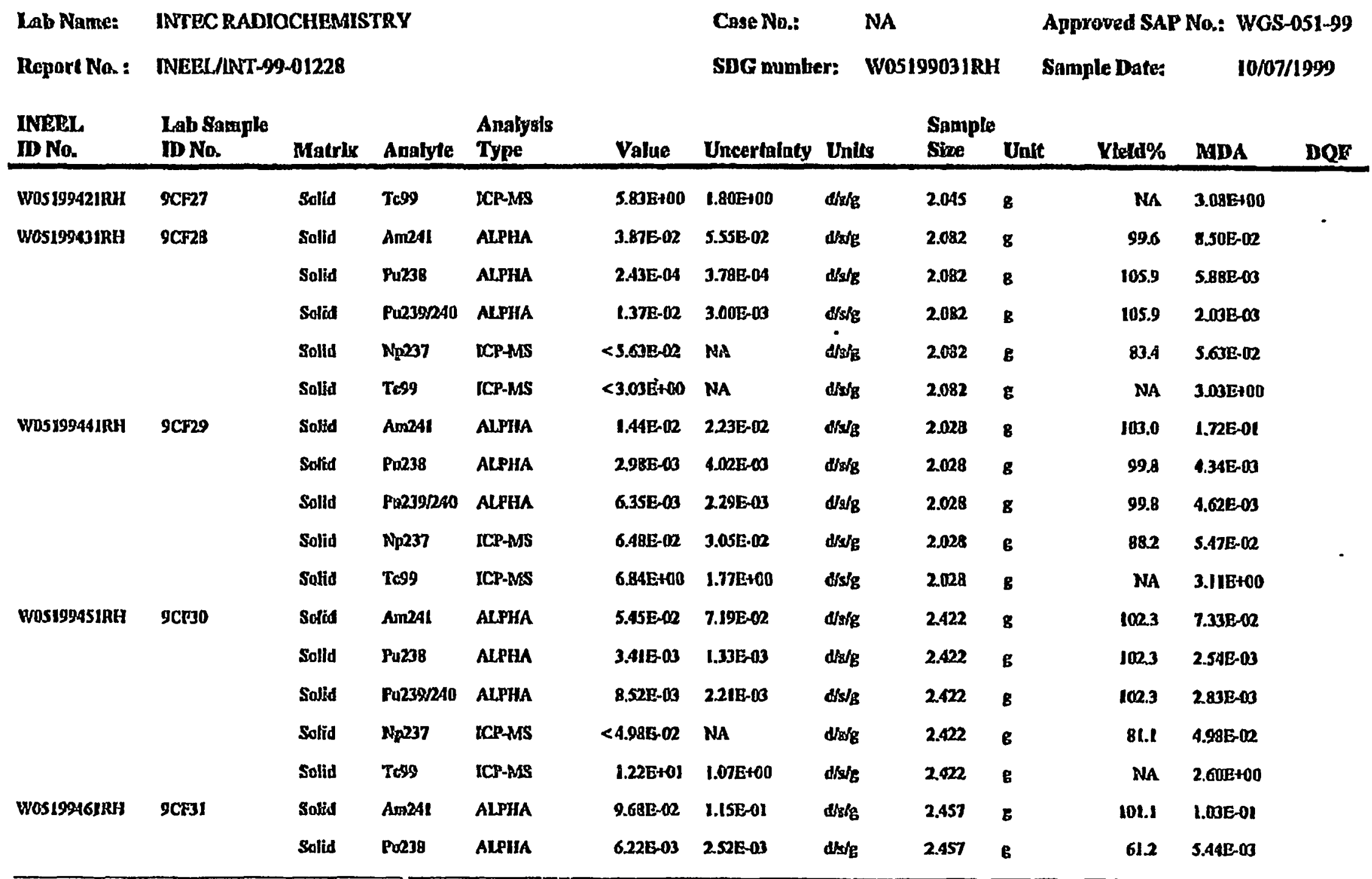




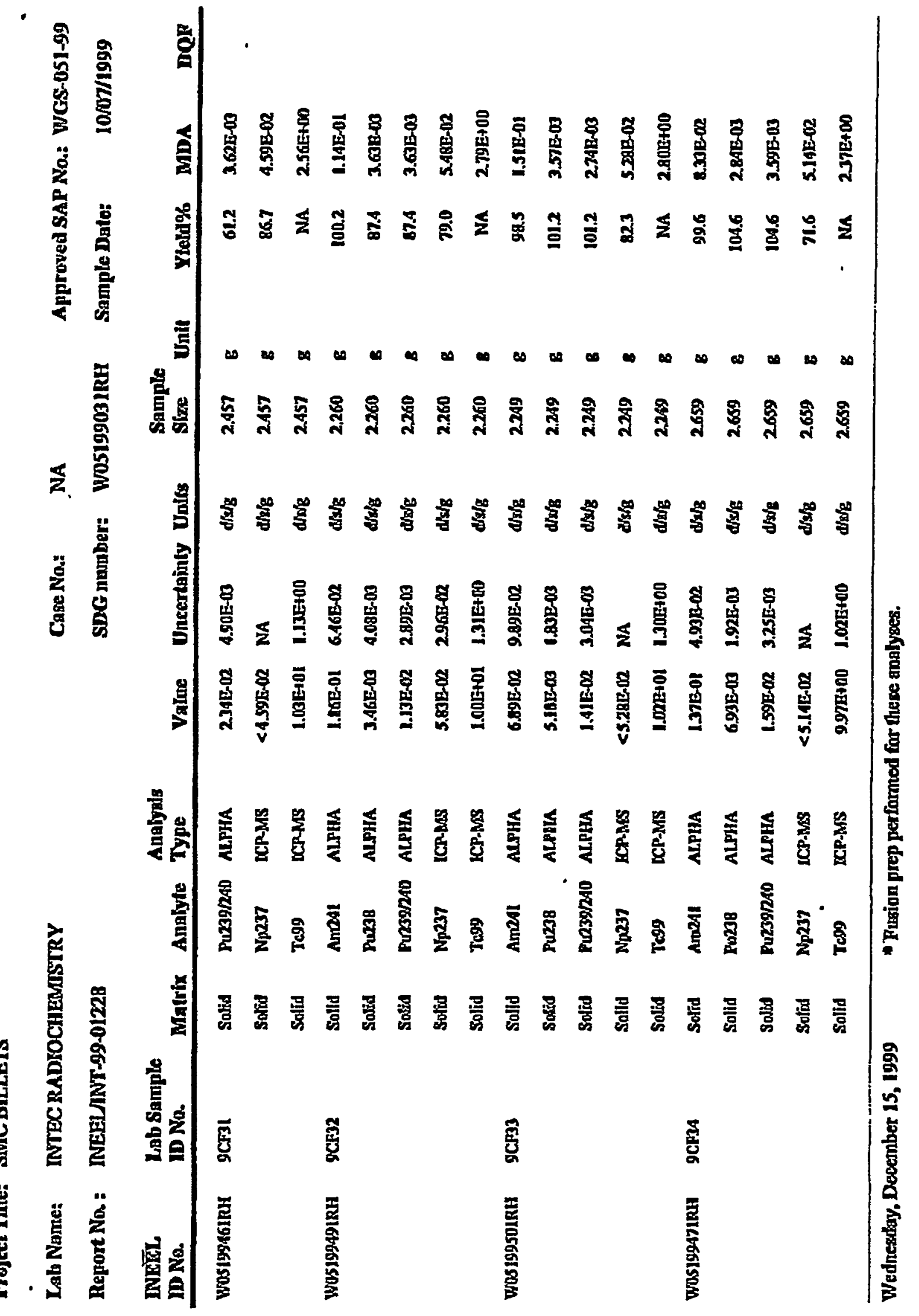


Project Tille: SMC BILLATS

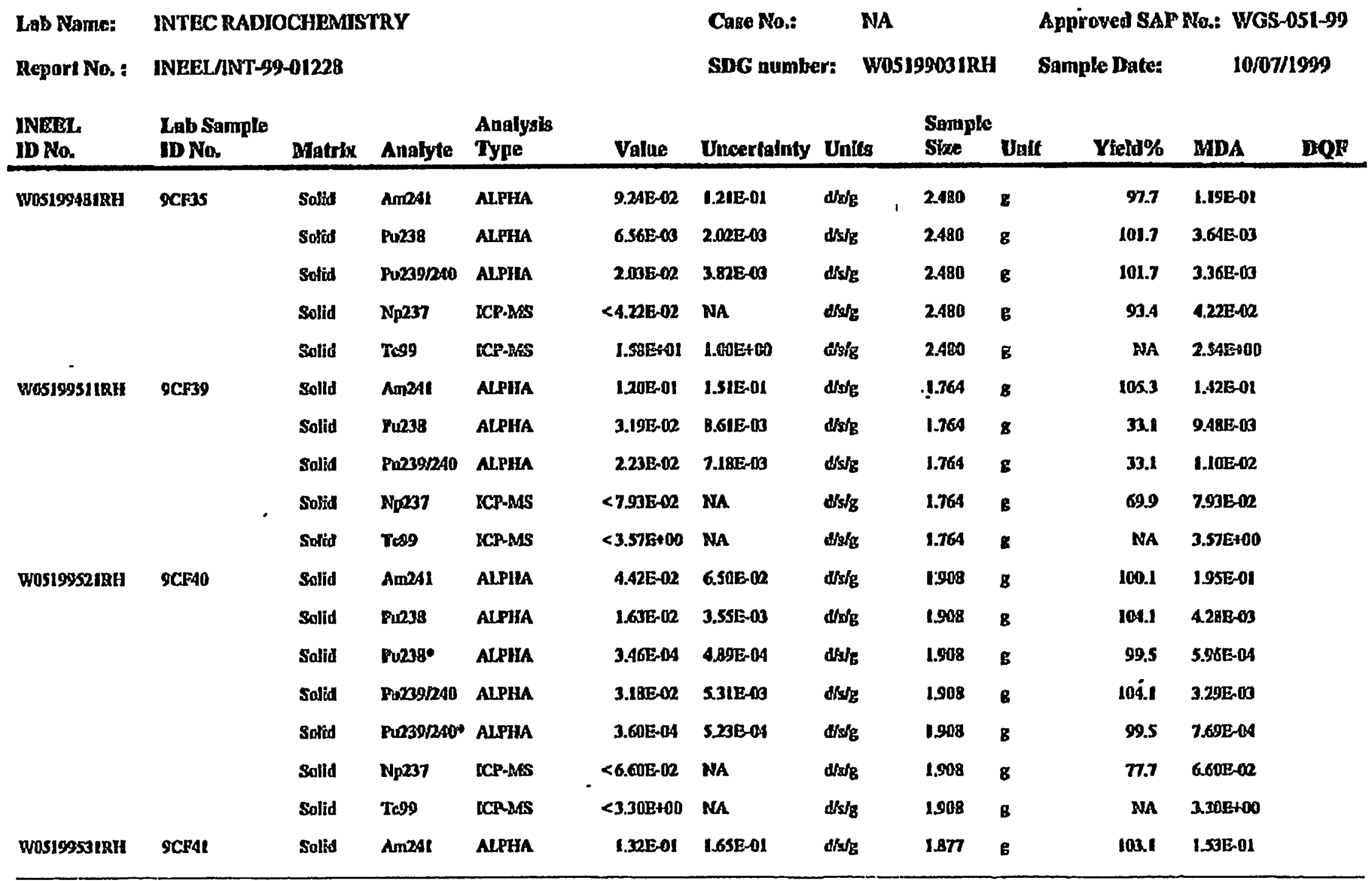




\section{Project Title: SMCDILLETS}

\begin{tabular}{|c|c|c|c|c|c|c|c|c|c|c|c|c|}
\hline \multirow{2}{*}{$\begin{array}{l}\text { Lab Name: } \\
\text { Report Na. } \\
\text { INĒEL. } \\
\text { ID Na. }\end{array}$} & \multicolumn{5}{|c|}{$\begin{array}{l}\text { INTEC RADIOCHEMISTRY } \\
\text { DNEEIJNT-99-01228 }\end{array}$} & \multicolumn{2}{|c|}{$\begin{array}{l}\text { Case Na: } \\
\text { SDG number: }\end{array}$} & $\begin{array}{l}\text { NA } \\
\text { WOS19903IRH }\end{array}$ & \multicolumn{4}{|c|}{$\begin{array}{l}\text { Asproved SAP No.: WGS-051-99 } \\
\text { Sample Date: } \quad 10 / 07 / 1999\end{array}$} \\
\hline & $\begin{array}{l}\text { Lab Somple } \\
\text { ID No. }\end{array}$ & Malrix & Analyte & $\begin{array}{l}\text { Analysis } \\
\text { Type }\end{array}$ & Value & Uncertainty & Units & $\begin{array}{l}\text { Sample } \\
\text { Slaxe }\end{array}$ & Unit & nolds & MDA & DQF \\
\hline \multirow[t]{4}{*}{ WOS199531RH } & SCRAI & Solid & Pros3: & ALPHA & 1.508202 & 3.48E-03. & $d / 8$ & 1.877 & B & 92.0 & $3.81 E-03$ & \\
\hline & & Soffid & Puzas240 & ALPHA & 1.S6E-OR & 4.15E-13 & $\mathbf{w} / \mathrm{s}$ & 1.877 & $\mathbf{E}$ & 92.0 & 4.25E-10 & \\
\hline & & Solid & Np237 & ICPAAS & $<7.05 E-02$ & $M A$ & $d / 3 / g$ & $1.8 n$ & $\mathbf{B}$ & 73.9 & 7.05E-102 & \\
\hline & & Solld & Tos9 & KCP-MS & 5.05Et0D & $1.96 \mathrm{E}+00$ & 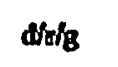 & 1.677 & $\mathbf{g}$ & NA & $3.36 \mathrm{E}+00$ & \\
\hline \multirow[t]{5}{*}{ WOSI9954IRH } & SCF42 & Solitid & Amzal & AlPIIA & I.9SE-ọ! & $8.09 \mathrm{E}-102$ & diols & 2.019 & B & 102.0 & $1.87 t-01$ & \\
\hline & & Solid & Prop38 & ALPIIA & 1.765 .02 & 3.76E-03 & $d w_{B}$ & 2019 & 8 & 9R.S & 4.36E- 03 & \\
\hline & & Solld & PU239240 & ALPHA & $2.21 \mathrm{E}-12$ & $4.36 E-03$ & $d / x=$ & 2.019 & E & 98.5 & 4.90E-03 & \\
\hline & & Salld & Np237 & ICP-BS & $<1.138-01$ & NA & dos/g & 2.019 & 8 & 42.9 & I.13B-0| & \\
\hline & & Solid & Tes & XCRASS & $1.231 \mathrm{E}+01$ & 139E-10D & dossig & 2.019 & E & $\mathbf{N A}$ & $3.12 B+00$ & \\
\hline \multirow[t]{5}{*}{ WOSIS95SIRH } & $9 \mathrm{CP43}$ & Solld & Am2aI & ALPHA & 133E-01 & I.S7E-OI & wore & 2.044 & $\mathbf{8}$ & 107.0 & 1.4015-01 & \\
\hline & & sofind & Purass & ALPHA & $1.66 \mathrm{R}-02$ & $3,91 \mathrm{E}-03$ & $d x / 6$ & 2.049 & E & 109.1 & $6.61 E=00$ & \\
\hline & & solid & Pussopado & ALP̈HA & 2.75E-02 & 1.09E-03 & ANAB & 2.044 & e & 103.1 & $2.172-\infty 8$ & \\
\hline & & salld & Np237 & ICPAAS & $<6.826 .02$ & $\mathbf{N A}$ & $d x / B$ & 2.044 & B & 70.2 & 6.8250202 & \\
\hline & & Softd & $\operatorname{Tos} 9$ & ICPAS & B.27Et0D & $1.65 \mathrm{E}+00$ & $d u_{k}$ & 2.044 & E & $\mathrm{M} \Omega$ & $3.08 E+00$ & \\
\hline \multirow[t]{4}{*}{ WOSI9956IRH } & SCP44 & solid & Am241 & ALPHA & $1.43 \mathrm{E}-0 \mathrm{~d}$ & $6.088-102$ & dorfe & 1.824 & 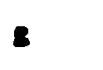 & 200.5 & 1.21E-01 & \\
\hline & & solid & Pirz38 & AlPHA & G.19R-03 & $2.37 \mathrm{E}-03$ & dowe & 1.824 & $\mathbf{z}$ & $\cos 2$ & S.25E-03 & \\
\hline & & Soltid & Puess" & ALPtA & $-4.455-05$ & 2.17E-05 & $d x_{1 / B}$ & 1.824 & g & 93.2 & $4.68 \mathrm{E}-04$ & \\
\hline & & Solid & P02391240 & ALPHA & 1.08B-02 & 2998-03 & $d s_{B}$ & 1.824 & E & 105.2 & 49812-03 & \\
\hline
\end{tabular}

Wednestay, December 15, 1999 *Furion prep performed for these analyses. 
Project Title: SMC BILLETS

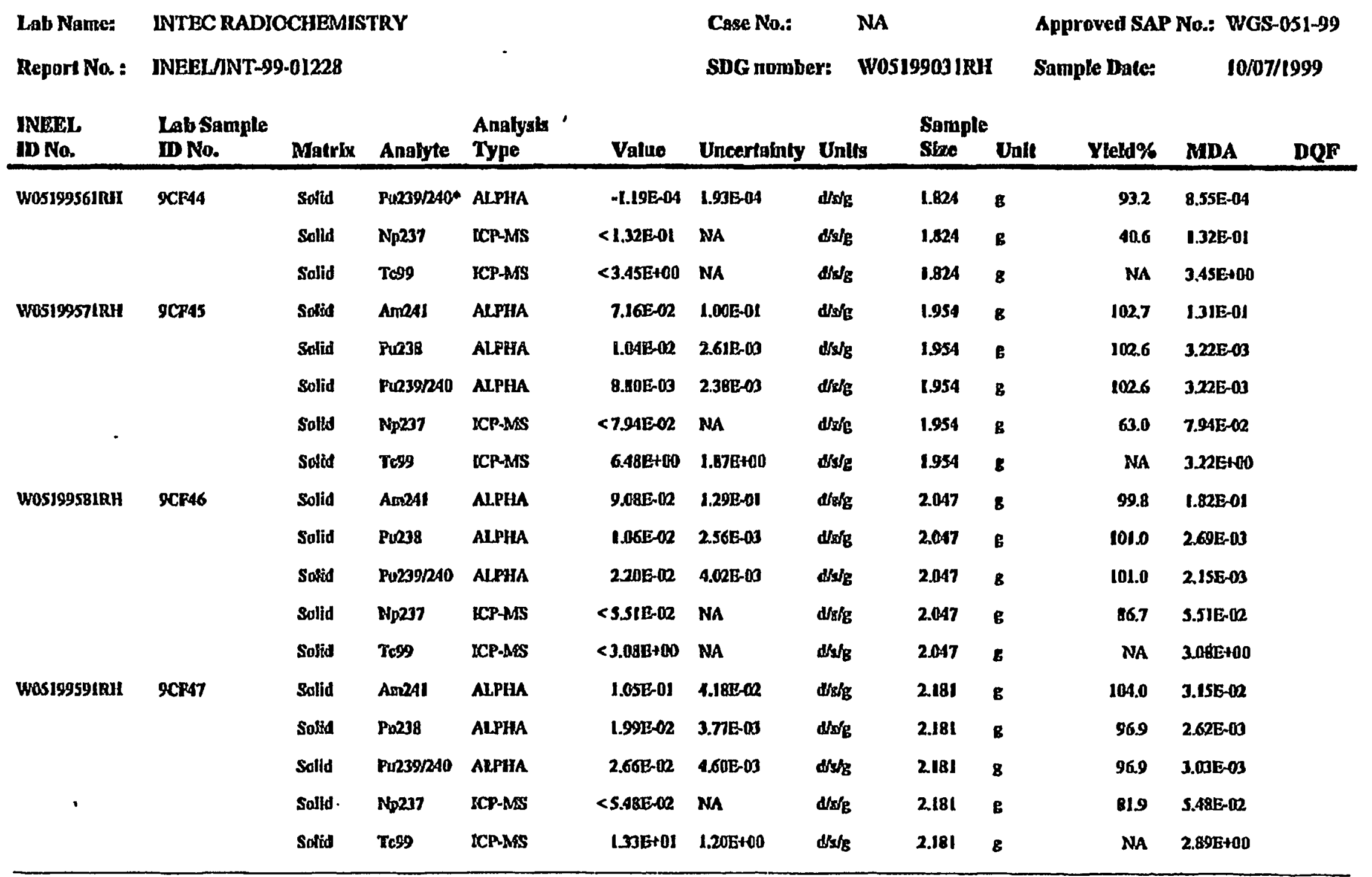


Projeet THic: SMC BILLETS

\begin{tabular}{|c|c|c|c|c|c|c|c|c|c|c|c|c|}
\hline \multirow{2}{*}{$\begin{array}{l}\text { Lab Name: } \\
\text { Report No.: } \\
\text { INRRt. } \\
\text { ID Na. }\end{array}$} & \multicolumn{5}{|c|}{$\begin{array}{l}\text { NTEC RADIOCHEMISTRY } \\
\text { INEEJ/NT-99-01228 }\end{array}$} & \multicolumn{2}{|c|}{$\begin{array}{l}\text { Care Na: } \\
\text { SDG number: }\end{array}$} & $\begin{array}{l}\text { NA } \\
\text { WoS19903IRH }\end{array}$ & \multicolumn{4}{|c|}{$\begin{array}{l}\text { Approved SAP No: WGS-OSI-99 } \\
\text { Sample Date: } \\
\text { 10/07/1999 }\end{array}$} \\
\hline & $\begin{array}{l}\text { Lab Sample } \\
\text { ID No. }\end{array}$ & Matrix & Amalyte & $\begin{array}{l}\text { Analyzis } \\
\text { Type }\end{array}$ & Value & Uecertainty & Unils & $\begin{array}{l}\text { Sample } \\
\text { Sime }\end{array}$ & Unil & Ytedr & MDA & DQP \\
\hline \multirow[t]{7}{*}{ WosisgrolRH } & 9CFAl & Solid & AmRaI & ALPHA & $1218-01$ & $4.676-62$ & arets & 2.563 & 8 & 101.1 & -.52E- 02 & \\
\hline & & sofid & Pues38 & ALPHA & 9.41E-OS & $2.285-03$ & ans & 2563 & E & 101.6 & $3.046-03$ & - \\
\hline & & solid & Preser: & ALPHA & $1.02 E-05$ & $1.61 \mathrm{E}-05$ & ants & 2.563 & 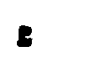 & 98.5 & 1.56E-04 & \\
\hline & & Solid & Pros39240 & ALPHA & $2.086-102$ & $3.668-03$ & $d x / 8$ & 2.563 & 8 & 101.6 & $2.51 E-\infty 0$ & \\
\hline & & Salid & Par3anz10* & Alstu & 2.53E-AR & $1.36 \mathrm{E}-44$ & othe & 2.563 & 8 & 98.5 & $1.385-04$ & \\
\hline & & solid & Np237 & ICP-MAS & $<4,43 E-12$ & NA & ditht & 2.563 & 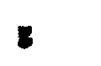 & ea. & 4.43E-QR & \\
\hline & & solld & To9 & ICP-MS & $1.50 E+01$ & 9.6AER & 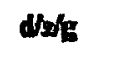 & 2.560 & 8 & $\mathbf{M A}$ & 2.46E+0B & \\
\hline \multirow[t]{5}{*}{ WOSI996IJRH } & scr4s & Solld & Am2AI & ALPHA & $3.09 \mathrm{E}-102$ & $5.63 \mathrm{E}-02$ & $d x / z$ & 1.273 & 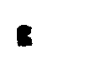 & 101.0 & 245E-0I & \\
\hline & & Solid & Pnose & AlPA & 4.501013 & $6.76 \mathrm{E}-13$ & $d / 2$ & 1.273 & 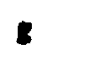 & 70.2 & S.21E- -93 & \\
\hline & & Solvid & Pwe239240 & ALPHA & $0.00 E+00$ & $5.00 \mathrm{E}-04$ & dhre & 1.273 & 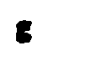 & 70.2 & $1.998-03$ & \\
\hline & & soltd & 1p237 & XCPMS & $<1.306-01$ & $\mathbf{M}$ & $d x / 6$ & 1.273 & . & 59.3 & $1.300-01$ & \\
\hline & & solid & Ta9 & LCRMS & C495E+100 & NA & $d x$ & 1.273 & 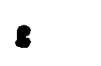 & NA & $4.95 \mathrm{E}+00$ & \\
\hline \multirow[t]{5}{*}{ WAS199K2RRH } & SCFSO & solfed & AmReAl & AlfHA & $7.402-102$ & $1.028-08$ & Weds & 2.292 & $\varepsilon$ & 100.7 & $1.24 E .01$ & \\
\hline & & solid & Puzas & ALrita & 1.6FE-BB & $5.94 \mathrm{E}-1 \mathrm{~B}$ & $d x$ & 2292 & e & 64.9 & L.S9E-03 & \\
\hline & & Solid & Po39210 & ALPHA & $-3.568-04$ & $5.686-84$ & drte & 2.292 & 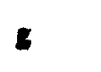 & 64.9 & $2.976-03$ & \\
\hline & & Solved & $N y 237$ & ICP-MAS & C6.74E-02 & NA & 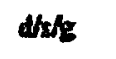 & 2.292 & 8 & 623 & 6.70E-102 & \\
\hline & & solid & Tose & XCP-NS & $<2.75 E+100$ & MA & $d / 2 \times / 8$ & 2.292 & 8 & $\mathbf{N A}$ & $2.750+00$ & \\
\hline Wosig9211RA & Sces1 & solid & $\operatorname{Am} 241$ & ALPHA & INOE-OI & $6.931-12$ & derte & 2.250 & $\mathbf{E}$ & 99.8 & IATE-0I & \\
\hline
\end{tabular}

Wednesday, December 15, 1999

* Pusian prep performed for these analyses. 
Project Title: SMC BILLETS

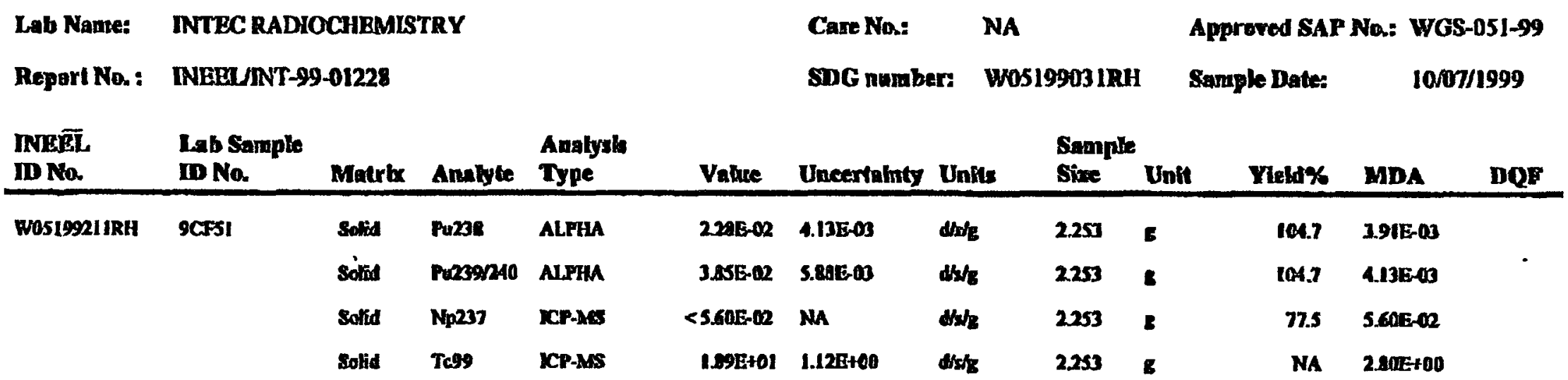

